\title{
Quantity and Sources of Base Flow in the San Pedro River near Tombstone, Arizona
}

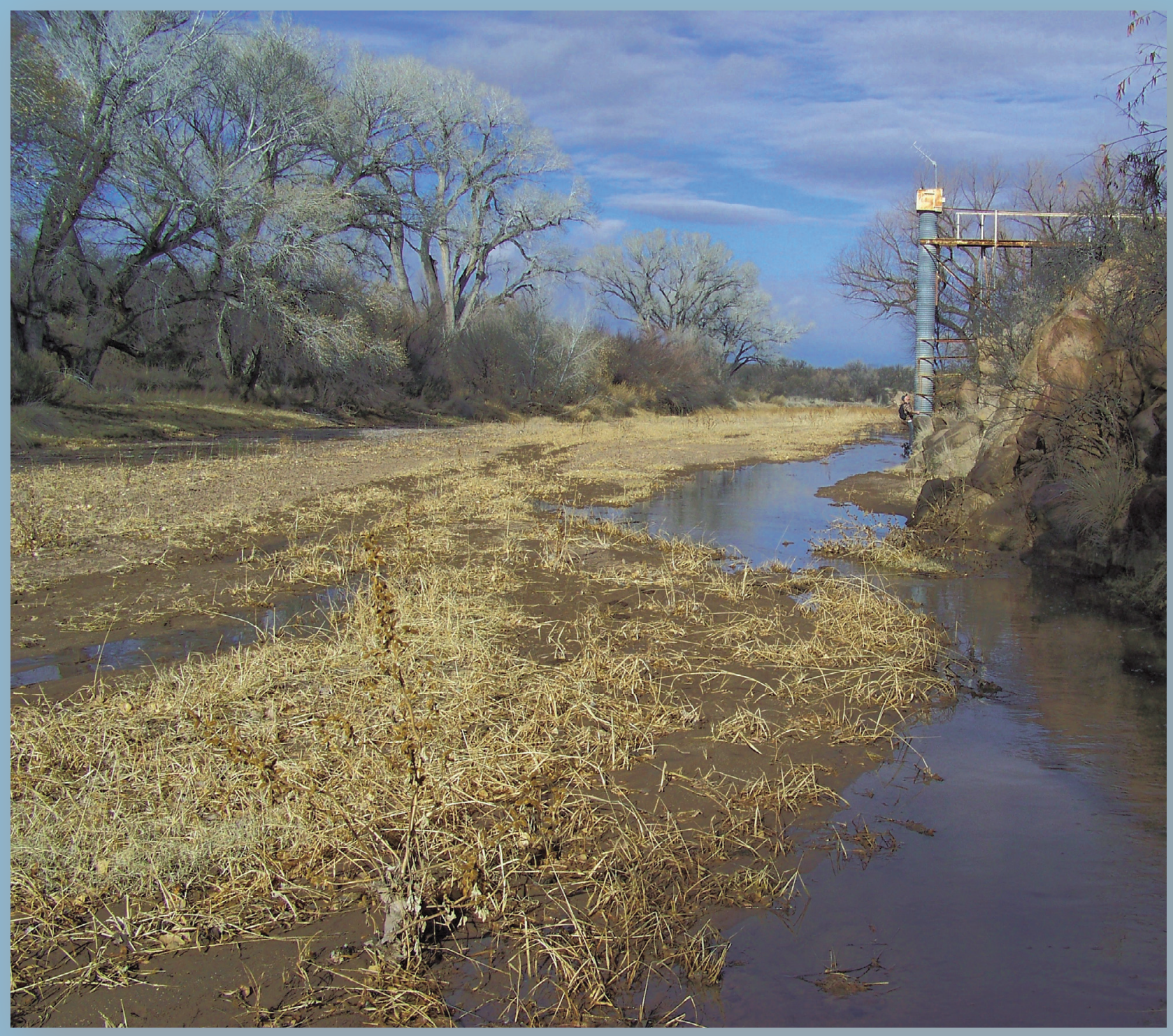

Scientific Investigations Report 2010-5200

U.S. Department of the Interior

U.S. Geological Survey 
COVER: The start of winter base flow in the San Pedro River near Tombstone (station number 09471550) on December 29, 2009. Photo is looking downstream. On this day, all discharge had infiltrated into the stream channel about $100 \mathrm{~m}$ downstream of the gage (Photograph by J.R. Kennedy.) 


\section{Quantity and Sources of Base Flow in the San Pedro River near Tombstone, Arizona}

By Jeffrey R. Kennedy and Bruce Gungle

Scientific Investigations Report 2010-5200 


\section{U.S. Department of the Interior \\ KEN SALAZAR, Secretary}

\section{U.S. Geological Survey \\ Marcia K. McNutt, Director}

\section{U.S. Geological Survey, Reston, Virginia 2010}

This report and any updates to it are available online at:

http://pubs.usgs.gov/sir/2010/5200

For more information on the USGS - the Federal source for science about the Earth, its natural and living resources, natural hazards, and the environment:

World Wide Web: http://www.usgs.gov or call 1-888-ASK-USGS (1-888-275-8747)

For an overview of USGS information products, including maps, imagery, and publications, visit http://pubs.usgs.gov/pubprod/

To order this and other USGS information products, visit http://store.usgs.gov

Any use of trade, product, or firm names is for descriptive purposes only and does not imply endorsement by the U.S. Government.

Although this report is in the public domain, permission must be secured from the individual copyright owners to reproduce any copyrighted material contained within this report.

Suggested citation:

Kennedy, J.R., and Gungle, Bruce, 2010, Quantity and Sources of Base Flow in the San Pedro River near Tombstone, Arizona: U.S. Geological Survey Scientific Investigations Report 2010-5200, 43 p. 


\section{Contents}

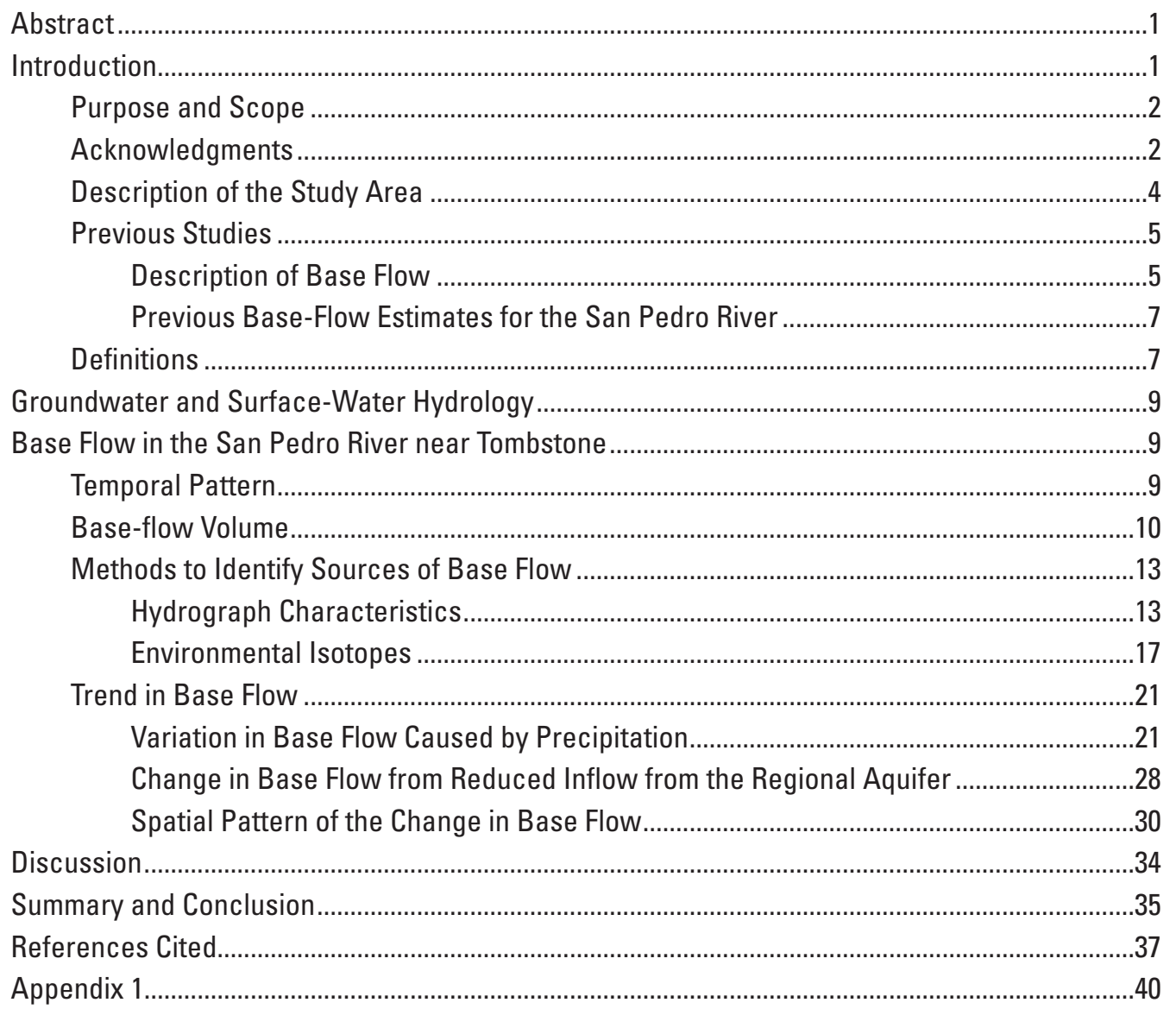

\section{Figures}

1. Map of the upper San Pedro River basin showing the location of stream-flow gaging stations, piezometer well pairs, and geographic features.

2. Graph showing streamflow at San Pedro River near Tombstone, Arizona (station number 09471550), June 2000 to June 2003.

3. Graph showing seasonal distribution of streamflow at San Pedro River near Tombstone, Arizona (station number 09471550).

4. Graph showing comparison of four base-flow separation methods applied to the streamflow record at San Pedro River near Tombstone gage (station number 09471550). The start of winter base flow is identified as the local minimum in the fall, shown as the vertical dashed line.

5. Flow duration curves and stream hydrographs at San Pedro River near Tombstone (station number 09471550) for 1968-1986 and 1997-2009. Blue points indicate streamflow during the months of November through June; red points are July through 0ctober. Vertical dotted line shows the 25th percentile..........................................................15

6. Scatter plot of winter base-flow volume vs. flow percentile. .......................................16 
7. Streamflow at San Pedro River near Tombstone (station number 09471550) September 2002 to May 2005. Blue dots indicate average base flow contribution to streamflow.

8. Streamflow at San Pedro River near Tombstone (station number 09471550) for 1980 to 1981, and 1998 to 1999, showing comparison of the average base flow contribution to streamflow, based on the 2003 to 2005 record.

9. Graph showing mean hydrogen and oxygen ratios at selected sites along and near the San Pedro River. Winter base flow is the average of samples collected from December to March at discharge rates less than $20 \mathrm{cfs}$. Summer flow is the discharge-weighted average of samples collected from July to September. Horizontal and vertical error bars show \pm one standard deviation of the mean.

10. Graph showing hydrogen isotope samples collected during winter at the Charleston, Tombstone, and Babocomari River gages.

11. Map showing $\delta \mathrm{H} 2$ concentrations at regional and alluvial groundwater sampling sites. Shaded region shows the region for which the Sierra Vista-area isotopic composition is calculated.

12. Graph showing average monthly precipitation measured at Tombstone (NWS Coop ID 028619) from 1931 to 2009, and for data subsets from

1968 to 1986 and 1997 to 2009 .

13. Graph showing monthly precipitation measured at Tombstone from October through March for each year from 1967 to 2009. Each month is plotted according to the calendar year, not water year..

14. Scatter plot matrices of winter base flow (mean monthly flow after hydrograph separation) and monthly 3-day low flow vs. summer streamflow and winter precipitation. Red points represent the early period of record at the gaging station near Tombstone, from 1968 to 1986 , and blue points represent the later period, from 1997 to 2009. Values are the Pearson correlation coefficient.

15. Scatter plot matrices of four different base-flow metrics vs. summer streamflow and winter precipitation. Red points represent the early period of record at the gaging station near Tombstone, from 1968 to 1986, and blue points represent the later period, from 1997 to 2009. Values are the Pearson correlation coefficient

16. Graph of response surface showing the coefficient of determination (R2) for the summer streamflow vs. winter base-flow linear regression. Summer streamflow is calculated as the average mean daily flow over a time span of $n$ days, shown on the $y$-axis, centered on the date on the $\mathrm{x}$-axis.

17. Graph showing the response surface of the LOWESS multiple-regression model for varying values of the independent variables of December to January rainfall and cube-root of October mean daily flow. Red points are the measured base flow used to construct the model.

18. Graphs showing LOWESS regression diagnostic characteristics: $A$, scatter plot of measured vs. predicted base flow, B, regression residuals vs. predicted base flow, C, regression residuals vs. standard normal quantiles..

19. Graph showing measured and adjusted base-flow volume. Adjusted values are based on the LOWESS regression shown in figure 17.

20. Graphs showing vertical gradient and water-level elevation at eight paired wells near the San Pedro River. Wells are in order from north at the top to south at the bottom. Locations of wells are shown in figure 1 . Solid lines are pressure transducer measurements and triangles are tape-down measurements.. 
21. Box plots showing January and February 3-day low flow at San Pedro River at Palominas (station number 09470500), San Pedro River at Charleston (station number 09471000), and San Pedro River near Tombstone (station number 0471550). The early period of record is 1968 to 1981, and the late period of record is 1997 to 2009 ................33

\section{Tables}

1. Water recharged to and withdrawn/discharged from the regional aquifer underlying the Sierra Vista Subwatershed in 2006.

2. Base-flow discharge estimates at the Tombstone gaging station. Values are volume of base flow in acre-ft.

\section{6}

3. Base flow statistics for San Pedro River near Tombstone (USGS station number 09471550).

4. Median of the mean daily flow by month for the period from 1968 to 1986 and from 1997

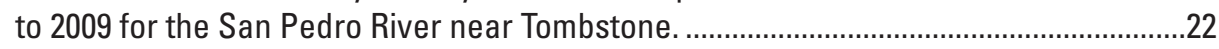

5. Data for wells used in vertical gradient analysis...........................................................30

\section{Appendix}

1. Annual hydrographs showing measured flow (black) and output from base-flow separation (measured flow with storm runoff removed) 


\section{Conversion Factors}

Inch/Pound to SI

\begin{tabular}{lcl}
\hline \multicolumn{1}{c}{ Multiply } & By & \multicolumn{1}{c}{ To obtain } \\
\hline acre-foot (acre-ft) & Volume & \\
\hline acre-foot (acre-ft) & 0.001233 & cubic meter $\left(\mathrm{m}^{3}\right)$ \\
\hline Flow rate & & cubic hectometer $\left(\mathrm{hm}^{3}\right)$ \\
\hline acre-foot per year (acre-ft/yr) & 1,233 & cubic meter per year $\left(\mathrm{m}^{3} / \mathrm{yr}\right)$ \\
\hline acre-foot per year (acre-ft/yr) & 0.001233 & $\begin{array}{l}\text { cubic hectometer per year }\left(\mathrm{hm}^{3}\right) \\
\text { yr) }\end{array}$ \\
\hline cubic foot per second $\left(\mathrm{ft}^{3} / \mathrm{s}\right)$ & 0.02832 & cubic meter per second $\left(\mathrm{m}^{3} / \mathrm{s}\right)$ \\
\hline
\end{tabular}

Temperature in degrees Fahrenheit $\left({ }^{\circ} \mathrm{F}\right)$ may be converted to degrees Celsius $\left({ }^{\circ} \mathrm{C}\right)$ as follows:

${ }^{\circ} \mathrm{C}=\left({ }^{\circ} \mathrm{F}-32\right) / 1.8$

Vertical coordinate information is referenced to the North American Vertical Datum of 1988 (NAVD 88).

Horizontal coordinate information is referenced to the North American Datum of 1983 (NAD 83).

Altitude, as used in this report, refers to distance above the vertical datum.

SI to Inch/Pound

\begin{tabular}{lll}
\hline \multicolumn{1}{c}{ Multiply } & By & \multicolumn{1}{c}{ To obtain } \\
\hline meter $(\mathrm{m})$ & Length & \\
\hline kilometer $(\mathrm{km})$ & 3.281 & foot $(\mathrm{ft})$ \\
\hline kilometer $(\mathrm{km})$ & 0.6214 & mile $(\mathrm{mi})$ \\
\hline meter $(\mathrm{m})$ & 0.5400 & mile, nautical $(\mathrm{nmi})$ \\
\hline
\end{tabular}

Temperature in degrees Celsius $\left({ }^{\circ} \mathrm{C}\right)$ may be converted to degrees Fahrenheit $\left({ }^{\circ} \mathrm{F}\right)$ as follows:

$$
{ }^{\circ} \mathrm{F}=\left(1.8 x^{\circ} \mathrm{C}\right)+32
$$




\title{
Quantity and Sources of Base Flow in the San Pedro River near Tombstone, Arizona
}

\author{
By Jeffrey R. Kennedy and Bruce Gungle
}

\section{Abstract}

Base flow in the upper San Pedro River at the gaging station (USGS station 09471550) near Tombstone, Arizona, is an important factor in the long-term sustainability of the river's riparian ecosystem. Most base flow occurs during the non-summer months (typically, from November to May), because evapotranspiration (ET) is greater than groundwater discharge to the riparian zone during the growing season and typically causes periods of zero flow in the spring and fall. Streamflow during the summer months occurs only as a result of rainfall and runoff. Using a hydrograph separation technique that partitions streamflow into stormflow and base flow, based on the change in runoff from the previous day, median base flow at the Tombstone gage from 1968 to 2009 (1987 to 1996 data absent) is 4,890 acre-ft/yr. Median base flow for the earlier period of record, 1968 to 1986 , is 5,830 acre-ft/yr and for the later period, 1997 to 2009, is 2,880 acre-ft/yr.

Base flow in the upper San Pedro River is derived from groundwater discharge to the river from the regional and alluvial aquifer. The regional aquifer is defined as having recharge zones away from the river, primarily at mountain fronts and along ephemeral channels. The alluvial aquifer is recharged mainly from stormflow. Based on environmental isotope data, the composition of base flow in the upper San Pedro River at the gaging station near Tombstone is $74 \pm 10$ percent regional groundwater and $26 \pm 10$ percent summer storm runoff stored as alluvial groundwater for the 2000 to 2009 period.

The volume of base flow in a given year is well explained, using multiple regression, by mean daily flow during the previous October and by rainfall during the months of December and January $\left(\mathrm{R}^{2}=0.9\right)$. This does not suggest that streamflow is composed only of these two sources; rather, these two sources control the degree of saturation of the nearstream alluvial aquifer and, therefore, the amount of winter base-flow infiltration that is possible upstream of the Tombstone gaging station. Because of losing conditions upstream of the Tombstone gage, there is no minimum amount of base flow that would be expected in any given year.
The regression equation was used to adjust the measured base flow to account for year-to-year variation in precipitation. Adjusted base flows decreased, independent of climate, from the early period of record to the late period of record. In addition to total base flow, other metrics were considered, including the start and end dates of base flow, the number of days of base flow, the 25 th percentile mean daily flow, and the number of days of zero flow. Each of these showed a decline in base flow between the early period of record and the late period. The available evidence to evaluate this decrease - hydraulic gradients in the alluvial and regional aquifers and a 10-yr record of streamflow environmental isotope samples - indicates that no reduction in groundwater discharge has occurred over this period of record. Continued regional groundwater pumping will, however, eventually lead to a decline in the contribution of regional groundwater to base flow.

\section{Introduction}

Riparian ecosystems depend on perennial streamflow to sustain plant and animal communities. Between rainfall events, the source of this streamflow is groundwater discharge, or base flow. In arid and semiarid environments, the presence or absence of base flow controls the extent of riparian ecosystems. In these environments, dry periods may last several months, and base flow becomes an increasingly important resource as other ecosystem water sources disappear. Because of this, knowledge of the sources and quantity of base flow is important to understanding these ecosystems and, in particular, their response to historical and future groundwater pumping. This report describes groundwater sources and quantity of base flow to the upper San Pedro River in southeastern Arizona.

The San Pedro River (fig. 1) is the last remaining stream in southern Arizona that has long perennial reaches. The riparian ecosystem that parallels the stream bed provides habitat for over 350 species of birds, 80 species of mammals, and 40 species of reptiles and amphibians. Several of these plants and animals are listed as federally endangered species (Bureau 
of Land Management, 1989; Rojo and others, unpub. data, 1999'). The biological importance of the San Pedro River's riparian ecosystem was formally recognized in 1988 by an act of Congress that created the San Pedro Riparian National Conservation Area (SPRNCA), the first of its kind. The SPRNCA stretches along the river from the international boundary with Mexico to a point north of the ghost town of Fairbank and south of St. David. The Bureau of Land Management (BLM) is responsible for managing and protecting the SPRNCA.

A regional groundwater budget is a tool used to evaluate the relative magnitude of inflows to and outflows from a given aquifer. The groundwater budget of the Sierra Vista Subwatershed (Subwatershed) of the Upper San Pedro Basin has been a topic of intense scrutiny for over two decades, principally because outflows from the regional aquifer-primarily groundwater pumping, evapotranspiration (ET), and streamflow-are greater than the rate of recharge. As a result, the annual groundwater deficit was about 5,200 acre-ft in 2006 (Department of the Interior, 2008). If total withdrawals from the regional aquifer continue at the present rate, reduction in groundwater discharge to the San Pedro River will lead to the eventual loss of perennial reaches and degradation of the riparian ecosystem.

Groundwater budgets are developed using the most precise estimates of inflows and outflows available. In the Subwatershed, inflows considered are recharge from mountain-block, mountain-front, ephemeral channel, and artificial infiltration and groundwater subflow. Outflows considered are streamflow, groundwater subflow, pumping, and ET. While exact measurement of each of these processes is not possible, the addition of extensive instrumentation over the past 10 years has greatly increased the amount of data available to make these estimates. As new data become available and are analyzed, groundwater budget components may be revised. For example, Scott and others (2006) published a comprehensive study of groundwater discharge from the SPRNCA via ET. Their work increased this value by 3,100 acre-ft over the previous best estimate, an amount equal to over 50 percent of the annual groundwater deficit in 2006, which was the first reporting year that the revised ET number was incorporated into Congressional reporting in compliance with P.L. 108-136, Section 321 (table 1) (Department of the Interior, 2008). Other sources of uncertainty in the regional water budget include the amount of pumping from wells of less than $35 \mathrm{gal} / \mathrm{min}$ pumping capacity. Such pumping is exempt from reporting requirements under Arizona law. Natural recharge along the Subwatershed mountain fronts and in the ephemeral stream beds is also extremely difficult to measure directly. Most studies have used estimates of groundwater discharge to the river, or "base flow," that then

\footnotetext{
${ }^{1}$ Internal report available from Commisssion for Environmental Cooperation: Rojo, H.A., Bredehoft, John, Lacwell, Ronald, Price, Jeff, Stromberg, Julie, and Thomas, G.A., 1999, Sustaining and enhancing riparian migratory bird habitat on the upper San Pedro River, final draft: Montreal, Commission for Environmental Cooperation, 123 p.
}

discharges from the Subwatershed to estimate this value. Base flow itself is another component of the water budget for which a wide range of values have been calculated over the years. Estimated base-flow discharge from the Subwatershed ranges from 2,800 to $7,400 \mathrm{acre}-\mathrm{ft} / \mathrm{yr}$ and is dependent upon the period of record evaluated (table 2).

Interest in this latter groundwater-budget component, base-flow discharge from the Subwatershed as measured at the streamflow-gaging station named "San Pedro River near Tombstone," herein referred to as the "Tombstone gage" (station number 09471550), has sharpened in recent years. In physical terms, an actual increase in the long-term, mean base-flow discharge at the Tombstone gage could indicate progress toward sustainability - more water is available from the regional aquifer to enter the river and is exiting the Subwatershed as surface flow. In terms of the water budget alone (with all other terms held constant-no change in the physical system), however, a larger outflow number means not only that there is more surface flow in the system than previously estimated but also that there is a larger annual deficit in the Subwatershed water budget. As a result, any refinement to this value will reflect an improved understanding of the physical system but may also have management implications.

As part of its continuous effort to improve the Subwatershed water budget, the Upper San Pedro Partnership has charged the U.S. Geological Survey (USGS) to conduct an analysis of base-flow discharge at the Tombstone gaging station to reduce the uncertainty currently found in the Tombstone gage base-flow estimates and to inform decision makers regarding the likely causes of changes over the period of record. The results of this analysis will be available to the Upper San Pedro Partnership for incorporation into future reports and to inform its discussion of the Tombstone gagingstation record. The current report fulfills these responsibilities.

\section{Purpose and Scope}

This report was prepared to define the volume of winter base flow at the streamflow-gaging station on the San Pedro River near Tombstone, Arizona, USGS station number 09471550, in support of the reporting requirements of the Upper San Pedro Partnership under P.L. 108-136, Section 321. The entire period of streamflow record, from 1968 to 1986 and from 1997 to 2009 , is considered. Other data presented are streamflow isotope samples from two sites on the San Pedro River and one site on the Babocomari River, precipitation measured at the City of Tombstone, Arizona, and water-level measurements at eight paired piezometers along the San Pedro River.

\section{Acknowledgments}

The analyses found here resulted from numerous discussions with persons interested in the science of the upper San 


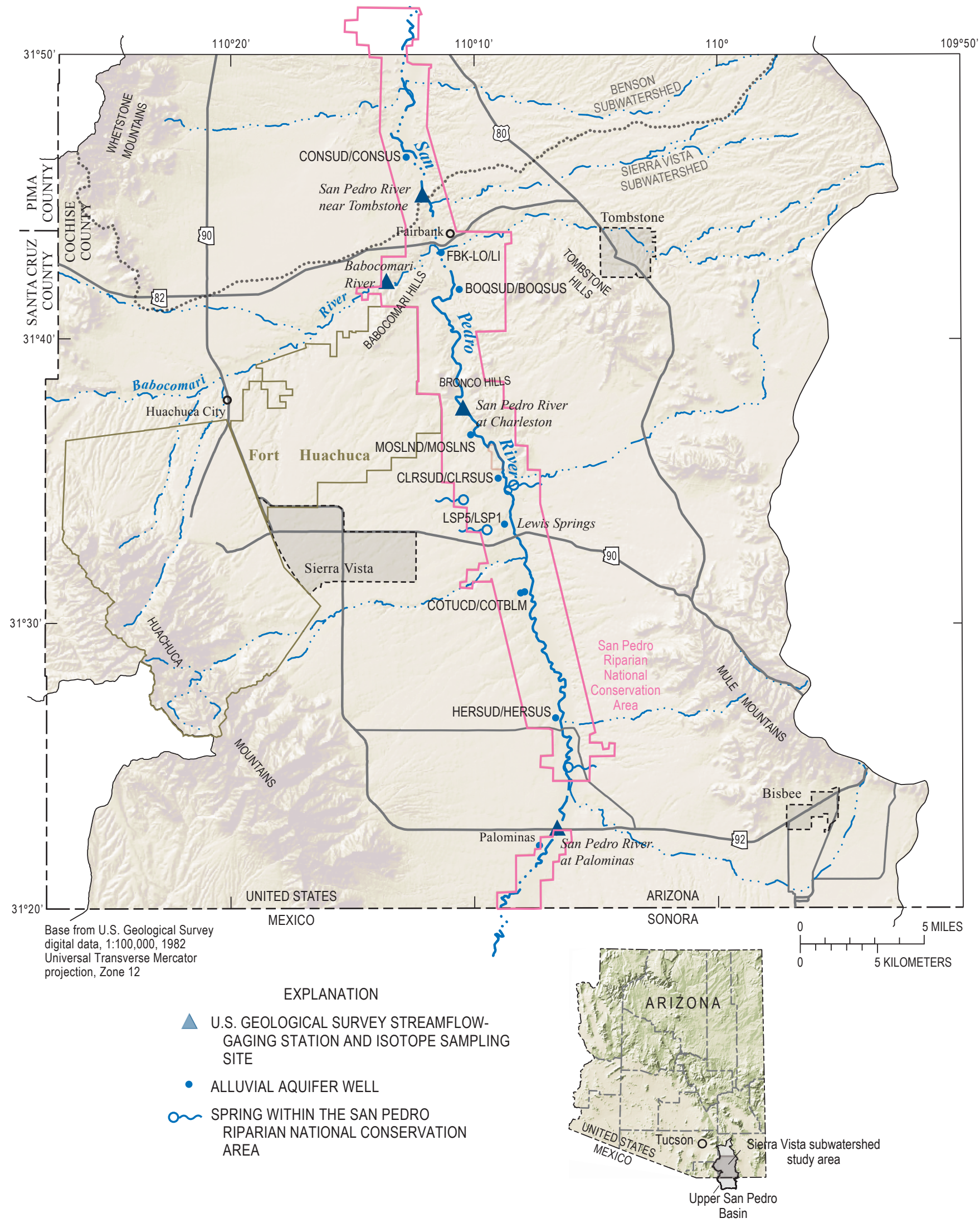

Figure 1. Map of the upper San Pedro River basin showing the location of streamflow-gaging stations, piezometer well pairs, and geographic features. 
Pedro River and its attendant riparian system. These include Jim Leenhouts of the USGS; Russ Scott of the Agricultural Research Service; Nate Dieterich, Paul Brown, and Tom Dabbs of the Bureau of Land Management; Tricia Gerrodette of Audubon Arizona; Tom Runyon of Fort Huachuca's Environment and Natural Resources division; and Holly Richter of The Nature Conservancy, among others. None of the current upper San Pedro research would be possible without the comprehensive work and thought of Don Pool of the USGS in Tucson. He is responsible for the original monitoring network across the Sierra Vista Subwatershed, not to mention the development of the conceptual framework, groundwater model, and related estimates of water budget components and hydrologic properties for the Subwatershed. Finally, the support and interest of the Upper San Pedro Partnership collectively and each of its 21 member jurisdictions, agencies, and organizations individually continue to support collection of data and drive the high quality of scientific research in the Sierra Vista Subwatershed.

\section{Description of the Study Area}

The Upper San Pedro Basin is a groundwater management unit that extends from the international boundary with Mexico to a bedrock constriction north of Benson, Arizona, called The Narrows. The San Pedro River runs south to north through the center of this basin. The surface watershed extends from the city of Cananea in the state of Sonora, Mexico, to the confluence with the Gila River at Winkelman, Arizona. The $2,460 \mathrm{~km}^{2}$ Sierra Vista Subwatershed is the southern subunit of the Upper San Pedro Basin; its northern boundary is located in the vicinity of the volcanic rocks of the Tombstone Hills near Fairbank that form a partial barrier to groundwater movement (Freethey, 1982).

The USGS gaging station near Tombstone (station number 09471550; Tombstone) is about $3 \mathrm{~km}$ north of the historic settlement of Fairbank along State Highway 82 and defines the north boundary of the Sierra Vista Subwatershed (fig. 1) (Department of the Interior, 2008). The Tombstone streamflow-gaging station was first installed by the USGS in 1967 and was used continuously through the end of September 1986, when the station was discontinued due to lack of funding and the recorder was removed from the gage house. In September of 1996, the gage datum was checked and, on October 1, 1996, the gaging station was reactivated with updated measuring equipment. Since 1996, the Tombstone gaging station has been in continuous operation, including basic maintenance and updates to the measurement equipment and reference marks. Additional upstream streamflowgaging stations on the San Pedro River are at Charleston, 14 km upstream (station number 09471000; Charleston), and Palominas, $41.5 \mathrm{~km}$ upstream and $6 \mathrm{~km}$ downstream from the international boundary with Mexico (station number 09470500; Palominas).
The Sierra Vista Subwatershed is part of a broad alluvial valley located in the southern part of the Basin and Range physiographic province and is bounded by fault-block mountains. To the east are the Mule Mountains (2,250 m elev) and the Tombstone Hills $(1,620 \mathrm{~m}$ elev $)$; to the west are the Huachuca Mountains (2,890 m elev) and the smaller Mustang Mountains (2,000 $\mathrm{m}$ elev) are in the northwest corner of the Subwatershed (fig. 1). The north flank of the Sierra San Jose (2,500 m elev), south of the Subwatershed in Mexico, drains into Greenbush Draw, a major ephemeral tributary that joins the San Pedro River from the east about $8 \mathrm{~km}$ north of the international boundary with Mexico.

The primary tributary to the San Pedro River in the Sierra Vista Subwatershed is the interrupted-perennial Babocomari River that enters the San Pedro River about $3.5 \mathrm{~km}$ south of the Tombstone gaging station. Opposite the Babocomari River, Walnut Gulch joins the river. Walnut Gulch and Greenbush Draw are the two major ephemeral tributaries that enter the river in the Subwatershed. Numerous other ephemeral tributaries empty into the river, with about twice as many on the west side of the Subwatershed as on the east side (Coes and Pool, 2005).

Precipitation falls preferentially on the mountains around the perimeter of the Sierra Vista Subwatershed and is temporally bimodal. About half falls during the summer convective season and about another third falls during the winter months. There is a distinct pre-summer drought from late April through June in most years. Tropical systems occasionally cause significant precipitation events during the fall (for example, 1972, 1977, 1983, 2000), and moderate to strong El Niño events can result in wet winters, with January and February typically receiving most of the precipitation (for example, 1978, 1984, 2010).

The major population centers in the Subwatershed (fig. 1) include Sierra Vista (population 46,597 in 2009, including Fort Huachuca), Bisbee (population 6,423), Huachuca City (population 1,955), and Tombstone (population 1,720) (Arizona Department of Commerce, 2010). Annual groundwater pumping and natural discharge in the Subwatershed exceeded natural and artificial recharge in 2006 by about 5,200 acre-ft; the majority of the groundwater pumping occurs between the Huachuca Mountains and the San Pedro River, in the vicinity of Fort Huachuca and Sierra Vista (table 1) (Department of the Interior, 2008).

Numerous studies have described in some detail the geology (Bryan and others, 1934; Brown and others, 1966; Hereford, 1993; Pool and Coes, 1999; Arizona Department of Water Resources, 2005a; Coes and Pool, 2005; Pool and Dickinson, 2007), biological resources (Hereford, 1993; Rojo and others, unpub. data, 1999; Leenhouts and others, 2005), climate (Arizona Department of Water Resources, 2005a; Leenhouts and others, 2005; Gungle, 2005; Thomas and Pool, 2006; Department of the Interior, 2008), and historical, cultural, and socioeconomic setting (Bryan and others, 1934; Hereford, 1993; Rojo and others, unpub. data, 1999; Arizona Department of Water Resources, 2005b; Department 
of the Interior, 2008) of the Upper San Pedro Basin. Please refer to these publications for more detail on specific basin characteristics.

\section{Previous Studies}

\section{Description of Base Flow}

Base flow in a natural channel is commonly defined as that contribution to streamflow composed solely of groundwater (Meyboom, 1961; Todd, 1980; Bedient and Huber, 1992). Whereas rainfall-induced stormflow is quickly delivered to the stream by overland and shallow subsurface flow, base flow represents the much slower transmission of water delivered to the stream via deeper groundwater flow (Freeze and Cherry, 1979). Once overland flow and near-surface flow have ceased, base flow in a perennial stream can be identified on the stream hydrograph as the subsequent period of quasi-exponential decay. This base-flow recession typically is consistent for each watershed and independent of such things as the magnitude of precipitation events or peak flows (U.S. Army Corps of Engineers, 1999). Separation of the stream hydrograph into stormflow and base-flow components is necessary to determine rainfall-runoff relations and related flood forecasting and can provide information about the nature of the groundwater regime in a given watershed. In particular, estimates of steadystate groundwater recharge and discharge are typically derived from annual base-flow volumes.

An exact definition of base flow varies depending on the author and focus of the study. Thomas and Pool (2006) caution that base flow should not be confused with all of the groundwater that moves toward a stream. In arid regions particularly, water removed by ET can represent a significant portion of all groundwater discharging to the riparian zone. If sufficiently high, ET demand can cause a negative hydraulic gradient and losing conditions in the immediate vicinity of the river, causing it to decline to zero flow, even though the hydraulic gradient in the regional aquifer may still force water into the near-stream zone. The quantity of base flow in an intermittent stream like the San Pedro River is thus strongly influenced by ET and may change over time due to both changes in ET and changes in regional hydraulic gradients, such as those caused by groundwater pumping.

Base-flow-separation techniques are intended to remove the high-frequency, short duration stormflow peaks seen on a stream hydrograph. The remaining streamflow is typically deemed "base flow," which can be derived both from mediumterm storage of stormflow in the near-stream aquifer ("bank storage") and from long-term storage in the regional aquifer, which is recharged primarily at the basin-bounding mountain fronts. The term "bank storage" implies storage in the shallow subsurface laterally away from the river, although storage may be primarily below the stream channel. Some authors use the term "base flow" as essentially synonymous with low flow, with sources including groundwater, bank storage, and other delayed discharge sources (Hall, 1968). Others more narrowly define base flow to mean only that part of streamflow derived from long-term, regional aquifer storage (Todd, 1980; Bedient and Huber, 1992; Thomas and Pool, 2006). Most authors consider bank storage a significant source of discharge immediately following high-flow events (for example, S.G. Brown and B.N. Aldridge, unpub. USGS administrative report, 1973; Freeze and Cherry, 1979; Todd, 1980), and Meyboom's (1961) discussion of bank-storage contributions to flood flows implies that bank storage and regional aquifer groundwater contributions together form base flow during floods. In intermittent streams, however, bank storage can also be an important source of water to streams long after a highflow event has passed. Kondolf and others (1987) indicate, for example, that bank storage along the Carmel River in California continued to provide surface flow to the river for two months after the last high-flow event of the wet season. Squillace (1996) made a similar observation about bank storage along the Cedar River in Iowa using a groundwater flow simulation. He found that a 2-m rise in river stage caused bank-storage water to move horizontally and vertically into the alluvial aquifer- 70 percent of the total bank-storage water moved vertically down through the river bed. Bank storage supplied base flow to the stream for 5 weeks following peak river stage. Whiting and Pomeranets' (1997) subsequent modeling work indicates that banks are capable of storing and slowly releasing such volumes of water, wider valleys sustain greater bank discharges longer than narrow ones, and sand and gravels store and discharge greater volumes faster than silt and clay. The authors note that a balance between yield and discharge duration is critical to maintaining base flow during periods of drought.

Hall (1968) defines base flow as deriving from not just a regional groundwater source, but also from the "portion of flow that comes from groundwater storage or other delayed sources" (p. 973; emphasis added), which would include bank storage that discharges over time. In other words, once enough time has passed, the water in the stream is considered base flow regardless of its source. Base flow may or may not include contributions from bank storage during and immediately following high flows, but it does include contributions from bank storage at some point adequately distant in time from the end of the last high-flow event.

Thomas and Pool (2006) initially distinguish between bank storage and short-term alluvial-aquifer storage in their statistical assessment of flow in the San Pedro River at the Palominas and Charleston gaging stations. They subsequently note, however, that the boundary between bank storage and short-term alluvial-aquifer storage is unclear and, thus, they consider the two as a single kind of bank storage, although separate from base flow as previously mentioned. Based on their observations at Palominas and Charleston, they determine that streamflow persistence in the San Pedro River is primarily a function of bank storage unrelated to monthly precipitation. Apparently they agree with the observations of Kondolf and others' (1987) and Squillace's (1996) observations noted above in everything except terminology. 
Table 1. Water recharged to and withdrawn/discharged from the regional aquifer underlying the Sierra Vista Subwatershed in 2006.

$[+$, inflows;,- outflows $]$

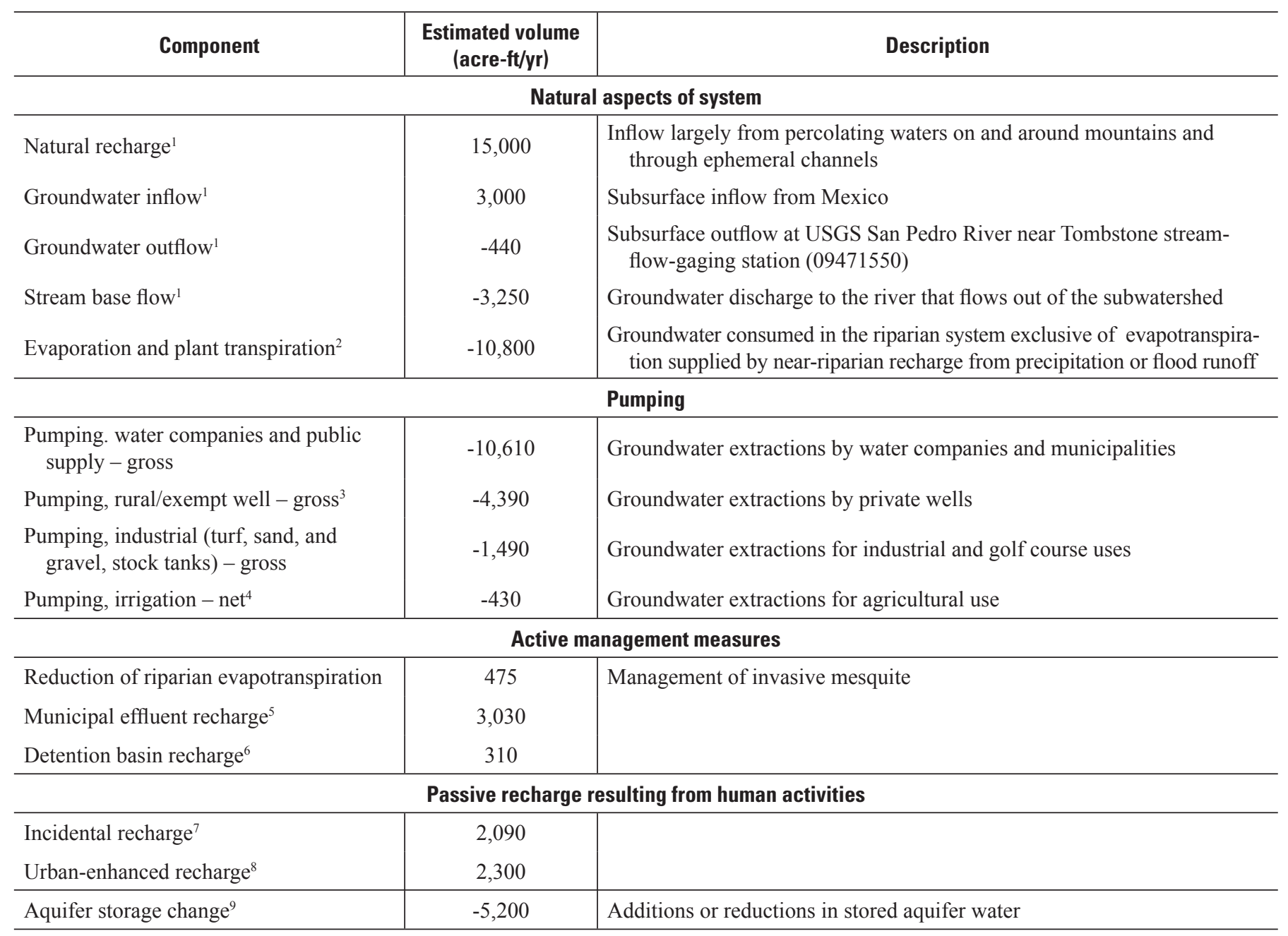

${ }^{1}$ Flow volume estimated by the Arizona Department of Water Resources (2005b).

${ }^{2}$ Value of evapotranspiration (ET) is the average of the high and low estimates of Scott and others (2006). This value replaces the 7,700 acre-ft/year estimate used in previous Section 321 reports (derived from Arizona Department of Water Resources, 2005b). The increase of 3,100 acre-ft annually does not necessarily suggest that actual ET has increased, but rather that the estimate of ET has increased.

${ }^{3}$ Value is lower than in previous Section 321 report owing to use of a revised calculation technique consistent with that of the Arizona Department of Water Resources (2005a). Exempt-well population derived from Arizona Department of Economic Security 2006 data. Earlier reports calculated population as number of exempt wells times 4.72 people per well (from Arizona Department of Water Resources, 2005a).

${ }^{4}$ Pumping for irrigation is consumptive use only. Area considered is the groundwater basin portion of the Sierra Vista Subwatershed only. The area within the boundaries of the Sierra Vista Subwatershed includes more agricultural lands than the area within the groundwater basin portion of the Subwatershed. These agricultural lands are primarily located in the head waters of the Babocomari River.

${ }^{5}$ Municipal effluent recharge is water returned to the aquifer through recharge facilities as reported by Sierra Vista (M. Hemesath, City of Sierra Vista Public Works, written commun., 2007), Fort Huachuca ( Fort Huachuca, 2007, Biological opinion annual report for 2006, 12 p.), City of Tombstone (Arizona Department of Water Resources, 2005a), and City of Bisbee (Russ McConnell, City of Bisbee Public Works, written commun., 2007)

${ }^{6}$ Recharge of stormwater within basins that have been installed to mitigate increased flood peaks in ephemeral-stream channels resulting from urbanization.

${ }^{7}$ Incidental recharge is an estimate of water returned to the aquifer from septic tanks and turf watering. Value reduced from prior Section 321 report owing to revised technique for calculating exempt-well pumping.

${ }^{8}$ Urbanization causes enhanced recharge by concentrating storm runoff in ephemeral-stream channels. Recharge in arid and semiarid environments is more likely to occur if runoff from precipitation reaches permeable stream-channel sediments. Recharge caused by urbanization only partially mitigates the increased pumping that accompanies increased urbanization.

${ }^{9}$ Value rounded to nearest 100 acre-ft/yr. 


\section{Previous Base-Flow Estimates for the San Pedro River}

Bryan and others (1934) wrote the first comprehensive review of the water resources of the San Pedro River valley and likely were first to make observations related to the base flow of the San Pedro. They noted that nearly all of the low-water discharge of both the Babocomari and San Pedro Rivers was being diverted for irrigation. Perhaps the earliest estimate of base flow on the San Pedro River came from Brown and Aldridge (S.G. Brown and B.N. Aldridge, unpub. USGS administrative report, 1973). Based on estimates of mountain-front recharge and underflow at the international boundary, base-flow discharge at Charleston was estimated to be 4,800 acre-ft/yr. No estimate was made for discharge at the Tombstone gaging station, which had begun operation in 1967. (This and other estimates of base flow discharge on the San Pedro River at Charleston and (or) at or near the Tombstone gage are compiled in table 2.)

A number of subsequent base-flow estimates for the San Pedro River occurred in concert with the development of groundwater models for the area. Freethey (1982) modeled pre-development (circa 1940) base flow near Tombstone to be about 7,500 acre-ft/yr. Modeled base flow for 1968 was about 4,300 acre-ft/yr and for 1977, 4,500 acre-ft/yr. Vionnet and Maddock (1992) updated Freethey’s (1982) model and estimated base-flow values for Charleston; they did not include base-flow values for discharge from the Subwatershed at the Tombstone gage, however. Corell and others (1996) estimated pre-development base flow at the Tombstone gage to be about 9,500 acre-ft/yr and base flow in 1990 to be about 6,450 acre-ft/yr. Their subsequent modeled results were lower: about 5,700 acre-ft/yr of base flow was simulated at the Tombstone gage for 1990. Goode and Maddock (2000) constructed a new groundwater model but, similar to Vionnet and Maddock (1992), did not look at the Tombstone gage base-flow discharge. Most recently, Pool and Dickinson (2007) developed a 5-layer Subwatershed model, including a 2-layer component for the Mexican part of the basin. Pre-development baseflow discharge at the Tombstone gage was estimated at 8,500 acre-ft/yr, while simulated pre-development base flow was higher, about 9,150 acre-ft/yr. Simulated base-flow discharge from March 2002 to March 2003 was about 2,800 acre-ft/yr. An important factor to note is that all of these groundwater models simulate only regional groundwater discharge to the river and disregard contributions from storage in the alluvial aquifer. The calibration process of each model is unique; however, where models are calibrated to measured streamflow, no efforts were made to separate alluvial aquifer and regional aquifer components of streamflow.

Other publications have also included estimates of and (or) observations about San Pedro River base flow. Rojo and others (unpub. data, 1999) used previous models and an analysis of 10-yr flow-duration curves to arrive at a Tombstone gage base-flow value of 7,400 acre-ft/yr in 1990. Pool and Coes (1999) found a declining trend in summer (June) base flow at the Charleston gage over the period 1936 to 1997 and observed that the long-term trend of decreasing wet-season (June-October) runoff is similar to the declining trend in summer base flow. They found no trend in winter base flow for the same period.

Whitaker (2000) estimated that bank-storage effects (both release of water from storage and the effect of bank storage on regional groundwater discharge) contributed about 8.5 percent of the total flow to the San Pedro River near Charleston from August to December, 1997. Using a 7-day low-flow analysis and the entire period of record, USGS estimated a value of 4,230 acre-ft/yr for the Tombstone gage base flow in 2002 (Department of the Interior, 2005). That analysis calculated base flow using the difference between annualized winter base flow and ET of 7,070 acre-ft/yr. If the more recent ET figure of Scott and others (2006) were used instead, the estimated base flow value would decrease greatly, to about 500 acre-ft/yr. The Arizona Department of Water Resources (Arizona Department of Water Resources, 2005a,b) determined a Tombstone gage base-flow value of 3,250 acre-ft/yr based on non-flood-influenced months between September and May during the period 1997-2003. This value is also used by the Upper San Pedro Partnership (2008) in the Subwatershed water budget as part of its reporting requirements under P.L. 108-136, Section 321. An extensive study by Thomas and Pool (2006) analyzed trends in the flow of the San Pedro River at Charleston. Using median monthly 3-day low flows, total base flow at Charleston was estimated to be 4,300 acre-ft for the period 1991-2002.

Unlike Tombstone, where ET is in excess of available nearstream groundwater, a summer base-flow contribution of 900 acre-ft was assumed for Charleston. Dieterich calculated a base flow value of 5,850 acre-ft/yr at the Tombstone gaging station based on median flow data from 1968-85 (Nathan Dieterich, Bureau of Land Management, written commun., 2009; Jim Kenna, Arizona BLM State Director, written commun., 2009).

Isotopic analysis can also be used to assist in separating groundwater from surface-water runoff in streamflow. Baillie and others (2007) present analysis of stable isotope and other geochemical tracers from the San Pedro River reach beginning at Palominas and ending at Charleston. A simple two-endmember mixing model of deuterium and hydrogen isotopes was evaluated, using the average $\delta \mathrm{H} / \delta \mathrm{O}$ isotope ratio of eight basin wells as one end member and the average $\delta \mathrm{H} / \delta \mathrm{O}$ ratio of summer precipitation as the other. Using this model, the authors found an increasing proportion of groundwater in base flow downstream, varying from $20 \pm 28$ percent at Palominas to $45 \pm 19$ percent at Charleston.

\section{Definitions}

The present study concerns specifically the groundwater discharge component of the water budget. Given the lack of consensus in the literature about what, specifically, composes 
Table 2. Base-flow discharge estimates at the Tombstone gaging station.

$[-$, no data $]$

\begin{tabular}{|c|c|c|c|c|c|c|}
\hline \multirow[b]{2}{*}{ Source } & \multirow{2}{*}{$\begin{array}{l}\text { Last time period } \\
\text { used in analysis }\end{array}$} & \multirow{2}{*}{$\begin{array}{l}\text { Method of estimating base } \\
\text { flow }\end{array}$} & \multicolumn{2}{|c|}{$\begin{array}{c}\text { Charleston gage } \\
\text { flow volume (acre-ft) }\end{array}$} & \multicolumn{2}{|c|}{$\begin{array}{c}\text { Tombstone gage } \\
\text { flow volume (acre-ft) }\end{array}$} \\
\hline & & & $\begin{array}{c}\text { Pre- } \\
\text { development }\end{array}$ & $\begin{array}{l}\text { Last time } \\
\text { period }\end{array}$ & $\begin{array}{c}\text { Pre- } \\
\text { development }\end{array}$ & $\begin{array}{l}\text { Last time } \\
\text { period }\end{array}$ \\
\hline $\begin{array}{l}\text { S.G. Brown and } \\
\text { B.N. Aldridge (unpub- } \\
\text { lished USGS administra- } \\
\text { tive report, 1973) }\end{array}$ & 1970 & $\begin{array}{l}\text { estimate of mountain } \\
\text { front recharge and } \\
\text { underflow }\end{array}$ & - & 4,800 & - & - \\
\hline $\begin{array}{l}\text { Vionnet and Maddock } \\
\text { (1992) }\end{array}$ & 1988 & model & 8,300 & 2,900 & - & - \\
\hline Corell and others (1996) & 1985-1991 & analysis of streamflow data & 9,500 & 4,800 & - & - \\
\hline Corell and others (1996) & 1990 & model (final year) & - & - & 9,500 & 5,700 \\
\hline $\begin{array}{l}\text { Goode and Maddock } \\
\quad(2000)\end{array}$ & 1997 & model & 9,600 & 6,400 & - & - \\
\hline $\begin{array}{l}\text { Arizona Department of } \\
\text { Water Resources (2005a, } \\
2005 b)\end{array}$ & $1997-2003$ & NA & - & - & - & 3,250 \\
\hline $\begin{array}{l}\text { USGS/Upper San Pedro } \\
\text { Partnership (2005) }\end{array}$ & $\begin{array}{r}\text { 1967-1986; } \\
1996-2002 \\
\end{array}$ & $\begin{array}{l}\text { 7-day winter low flow } \\
\text { and evapotranspiration }\end{array}$ & - & - & - & 4,230 \\
\hline Thomas and Pool (2006) & 1991-2002 & 3-day monthly low flows & 7,900 & 4,300 & - & - \\
\hline Pool and Dickinson (2007) & pre-development & $\begin{array}{l}\text { earlier estimates with } \\
\text { recent evapotranspiration }\end{array}$ & - & - & 8,500 & - \\
\hline Current study (2010) & $\begin{array}{l}1968-1986 \text { and } \\
1996-2009\end{array}$ & delta filter & - & - & - & 4,890 \\
\hline
\end{tabular}

base flow, we will use the following terminology to ensure conceptual clarity.

"Stormflow" refers to direct runoff from rainfall and also to the rapid release of water stored in the shallow subsurface immediately following a rainfall event. The period of stormflow following rainfall is on the order of days.

"Base flow" refers to water that flows in the river channel in the absence of any immediate influence from storm runoff; base flow is composed of regional groundwater, alluvial groundwater, or both. At the Tombstone gaging station, upstream groundwater flow to the vicinity of the stream is less than the volume of water removed by ET during the growing season; therefore, during the summer there is no base flow at the Tombstone gage.

In the context of streamflow, "regional groundwater" refers to groundwater from the regional aquifer that has discharged to the surface stream and is flowing between its banks. Regional groundwater is that portion of base flow composed entirely of groundwater discharged from the regional aquifer. It is water that has recharged away from the river.

"Alluvial groundwater" refers to water stored temporarily in the near-stream alluvium as distinct from "regional groundwater," which is sourced from the regional aquifer. In this context, alluvial groundwater is synonymous with bank storage 
but is used, instead, to clearly denote that storage occurs in a large zone surrounding the stream channel rather than strictly at the sides of the channel. Storage is typically on the order of days to months but may persist for a year or longer following very large runoff events. Alluvial groundwater does not include short-term storage during and immediately following storm runoff. While recognizing that, in many parts of the Subwatershed, the regional aquifer is well connected to the alluvial aquifer and that there may be little difference between the two, the concept of alluvial groundwater distinct from regional groundwater is important in the water-budget context. Alluvial groundwater is recharged by flood flows due to an increase in head and subsequent or increased negative hydraulic gradient (Whitaker, 2000). Most alluvial groundwater, in other words, has previously flowed in the stream channel of the San Pedro River (or Babocomari River); regional groundwater has not.

\section{Groundwater and Surface-Water Hydrology}

Between the Charleston gage and the Tombstone gage, the San Pedro River flows across the western portion of the Upper Cretaceous Tombstone volcanic-plutonic complex (Shipman and Ferguson, 2006). Low-lying, southwest-striking horst lie on either side of the river, separated by a southwestnortheast striking normal fault (Ferguson and others, 2006). The gaging station at Charleston lies on the southwest margin of this volcanic complex at a location where groundwater subflow is forced to the surface, resulting in perennial streamflow. This bedrock high is nearly continuous to the northeast towards the city of Tombstone and is assumed to be continuous with the Tombstone Hills volcanic complex (Shipman and Ferguson, 2006). The magnitude of groundwater flow through fractures and faults in the volcanic material is unknown but probably small relative to flow through the basin-fill aquifer to the west. As a result, the groundwater contribution to base flow east of the San Pedro River between the Charleston and Tombstone gages is expected to be minimal, although some amount likely occurs as subflow near Walnut Gulch, just upstream of the Tombstone gage. To the west of the river, surficial material is largely alluvium with the exception of an exposed elongate $3 \mathrm{~km}$ by $6 \mathrm{~km}$ horst of Cretaceous sedimentary rock capped by Uncle Sam Tuff (Ferguson and others, 2006). This block forms a subsurface barrier to flow near the confluence of the Babocomari River and the San Pedro River, which likely forces subflow near to or north of the gaging station near Tombstone. A groundwater channel that would direct flow from the north end of the Huachuca Mountains to the river has been postulated between the Babocomari Hills and the Bronco Hills (Corell and others, 1996) (fig. 1). Upstream from Charleston, the river flows across sedimentary material as much as $1.5 \mathrm{~km}$ thick (Gettings and Houser, 2000) and has no significant interaction with bedrock material.
Primary surface-water tributaries between Charleston and the Tombstone gage are the Babocomari River to the west, which drains about $800 \mathrm{~km}^{2}$ at the north end of the Huachuca Mountains and the Mustang Mountains, and Walnut Gulch to the east, which drains about $160 \mathrm{~km}^{2}$ starting at the southern end of the Dragoon Mountains. These tributaries join the San Pedro River nearly opposite one another at a point about 3 $\mathrm{km}$ upstream from the Tombstone gage, just south of Arizona Route 82. The Babocomari contains some sections of perennial flow but is intermittent at the confluence with the San Pedro River. Walnut Gulch is entirely ephemeral.

Both gaining and losing reaches exist upstream from the gaging station near Tombstone. The reach between the Charleston gage and the Tombstone gage is primarily losing, although water levels in co-located piezometers and in one horizontal transect indicate that, respectively, a consistent upward gradient exists in some locations and that at least one reach will shift from losing to gaining and back during the year (Leenhouts and others, 2005, appendix 3). Following the summer monsoon, near-stream sediments in this reach must remain saturated for perennial flow to exist at the gaging station near Tombstone. If summer streamflow is insufficient to maintain flow in the fall, upstream inflow must resaturate these sediments until seepage becomes sufficiently small and streamflow resumes. Gaining reaches are concentrated primarily between Arizona Route 90 and Charleston (Pool and Coes, 1999). Inflow to the stream channel in this area is derived from storage in both the alluvial and regional aquifers.

Groundwater discharged as base flow can be evaluated two ways. First, the total amount of groundwater discharge can be determined by taking the base-flow discharge rate for the period when vegetation is dormant and ET is minimal and integrating over every day of the year. The amount of ET, determined independently, can be subtracted from this yearround groundwater discharge to determine the amount of base flow. This method ignores ET-induced changes in hydraulic gradients and, therefore, changes in groundwater discharge rates. Second, base flow may be determined directly from the streamflow record using a hydrograph-separation method to remove stormflow peaks and integrating the actual amount of measured discharge. We focus on the second method.

\section{Base Flow in the San Pedro River near Tombstone}

\section{Temporal Pattern}

Streamflow at the San Pedro River near the Tombstone gage has a distinct seasonal pattern. Peak streamflow occurs in the summer during the North American monsoon, as convective thunderstorms produce infiltration-excess overland flow. Streamflow declines following the monsoon and typically reaches a minimum in October or November. In wetter years, such as 2001, stored alluvial groundwater sustains streamflow 
throughout the fall (fig. 2) (all dates refer to water years, October 1 through September 30). In drier years, such as 2002 and 2003, streamflow declines to zero following the summer monsoon. Following the first freezing temperatures in the fall, ET demands decrease dramatically (Goodrich and others, 2000) and streamflow returns, reaching a steady flow rate in midwinter in most years. In the driest years, such as 2003, base-flow discharge increases slowly in the fall, reaches a maximum for a short time in midwinter, and declines quickly in the spring with the onset of ET (fig. 2). In all but the wettest years, the river becomes dry in late spring or early summer, when ET demand is high and before the onset of the summer monsoon. The only exception during the period of record is 1979, when the river flowed continuously at the Tombstone gage from summer 1978 through spring 1980. The earliest date of zero flow in spring is May 2 (1996), and the latest date is July 8 (1972, when runoff-producing rainfall occurred in late May and June). The median first date of zero flow for the period of record is May 30, for the period 1968-1985 is June 13, and for the period 19962009 is May 16. In the 12 years that the San Pedro River near Tombstone declined to zero flow in the fall, the earliest date for the onset of winter base flow is October 21, and the latest date is December 16 (table 3). Eight of these twelve years occurred during the latter period of record, 1996 to 2009.

\section{Base-flow Volume}

Mean annual discharge of the San Pedro River at the gaging station near Tombstone varies widely, from 7,310 acre-ft/yr in 1997 to 113,300 acre-ft/yr in 1984. Average mean annual discharge for the period of record is 35,100 acre-ft/yr, and the median mean annual discharge is 29,500 acre-ft/yr. Twenty-seven percent of mean annual flow occurs during the month of August, and 53 percent of mean annual flow, or 18,600 acre-ft, occurs during the monsoon runoffdominated months of July, August, and September (fig. 3). October has the third-highest mean monthly flow of 5,160 acre-ft. Streamflow in October may be from remnant tropical storms, midlatitude fronts, base flow, or a combination of these. Total discharge from November through June is on average 32 percent of the total annual discharge, or 11,200 acre-ft. This amount primarily reflects discharge from both regional groundwater and alluvial groundwater but may also include a small component of direct storm runoff during certain years.

To determine mean annual base-flow volume, a baseflow-separation method can be used. Methods to quantify base flow include (1) low-flow indexes, in which some criteria, such as monthly 3-day low-flow discharge, is assumed to represent base flow for a given period, (2) flow-duration curve percentiles, for example, streamflow on all days when discharge is below the median (50th percentile) is considered base flow, and (3) hydrograph-separation methods. Low-flow indexes - typically the lowest mean daily flow averaged over a 3- or 7-day period in a given month-are problematic considering the temporal pattern of streamflow at the Tombstone gage. If calculated on a monthly basis in those months when base flow is increasing to or decreasing from the midwinter maximum (fig. 2, 2003), the minimum value at the start of the month (in fall) or end of the month (in spring) would not be representative of the monthly discharge. As a result, base flow would be underestimated. Nonetheless, low flow indexes provide a useful measure of base flow requiring minimal

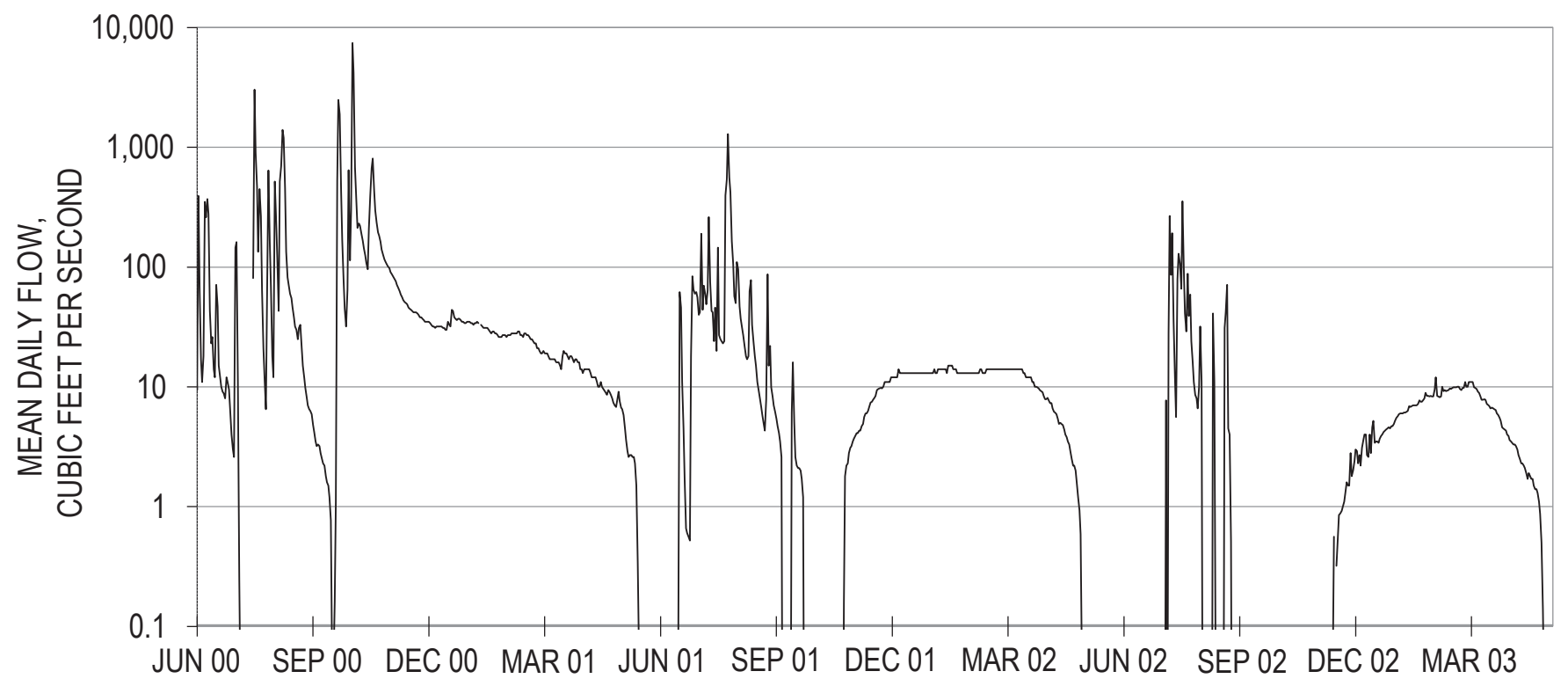

Figure 2. Graph showing streamflow at San Pedro River near Tombstone, Arizona (station number 09471550), June 2000 to June 2003. 
assumptions. Flow-duration-curve percentiles are widely used to delineate base flow, with the 50th percentile (the flow that is exceeded 50 percent of the time) being one of several possible base-flow metrics (Smakhtin, 2001). Flow duration curves for the San Pedro River near Tombstone, however, indicate that the winter base-flow discharge is somewhat higher than the 50th percentile flow. A hydrograph separation method and a flow-duration-curve metric are both used in this report to evaluate base flow at the gaging station near Tombstone.

Common hydrograph separation methods currently used are (1) streamflow partitioning into periods of either exclusively base-flow runoff or stormflow-influenced runoff, based on antecedent/concurrent precipitation or hydrograph characteristics (Shirmohammadi and others, 1984; Rutledge, 1998; Sloto and Crouse, 1996) and (2) low-pass filters that separate the high frequency stormflow signal from the low frequency base-flow signal (Boughton, 1993; Chapman, 1999; Eckhardt, 2005). Five hydrograph separation methods - four streamflow partitioning methods and one low-pass filter-were tested on the entire streamflow record at the Tombstone gage (fig. 4).

The USGS computer program PART (Rutledge, 1998) uses daily change in streamflow to partition streamflow. Intended primarily for periods of continuous flow, the PART algorithm requires that daily streamflow be less than streamflow the previous day to qualify as exclusively base flow. Because of this, it was unable to account for gradually increasing base flow in fall due to diminishing ET and it truncated the beginning part of the hydrograph (fig. 4). Another commonly used USGS program, HYSEP (Sloto and Crouse, 1996), also produced unacceptable results. The HYSEP algorithm identifies low points in the stream hydrograph in one of three ways: as the lowest daily streamflow in an $n$ day period, as the lowest daily streamflow in a sliding interval, or as local minima. As with PART, each of these underestimated streamflow during the fall when the river first begins to flow and in the spring when streamflow declines to zero (fig. 4). The method also tends to partition small day-to-day fluctuations in streamflow as stormflow. The "one-parameter" digital filter method (Eckhardt, 2005) was also found to be unsatisfactory. Parameters $a$, the base flow recession constant, and $B F I_{\text {max }}$, the maximum base flow index that can be modeled by the algorithm, were varied across a reasonable range ( 0.85 to 0.99 and 0.01 to 0.99 , respectively). $B F I_{\max }$ primarily controls the minimum streamflow value, but no reasonable parameter value was found that was satisfactory for both dry base-flow periods, with streamflow about $10 \mathrm{cfs}$, and wetter periods, with sustained base flow of $20 \mathrm{cfs}$ or more.

Because methods examined above were found to have limitations, we derived a new technique called the "delta filter" due to its reliance on a day-to-day discharge difference threshold. Similar to PART, the delta filter uses an increase or decrease in mean daily flow less than 2 cfs from the previous day to indicate base flow on that day (PART uses any decrease in streamflow from the previous day). If the increase or decrease in mean daily flow is $2 \mathrm{cfs}$ or greater than the day before, that day is considered stormflow-influenced, and a base-flow rate is linearly interpolated between the two nearest days of base-flow discharge. Through visual analysis of base-flow-separated hydrographs, we determined that a $2 \mathrm{cfs}$ threshold performed better - that is, neither too much stormflow nor too little was removed - than thresholds of 1 , 3,5 , or $10 \mathrm{cfs}$. Using the daily change in streamflow proved to be more successful than using a precipitation threshold to indicate base flow (a method not shown in fig. 4), due largely

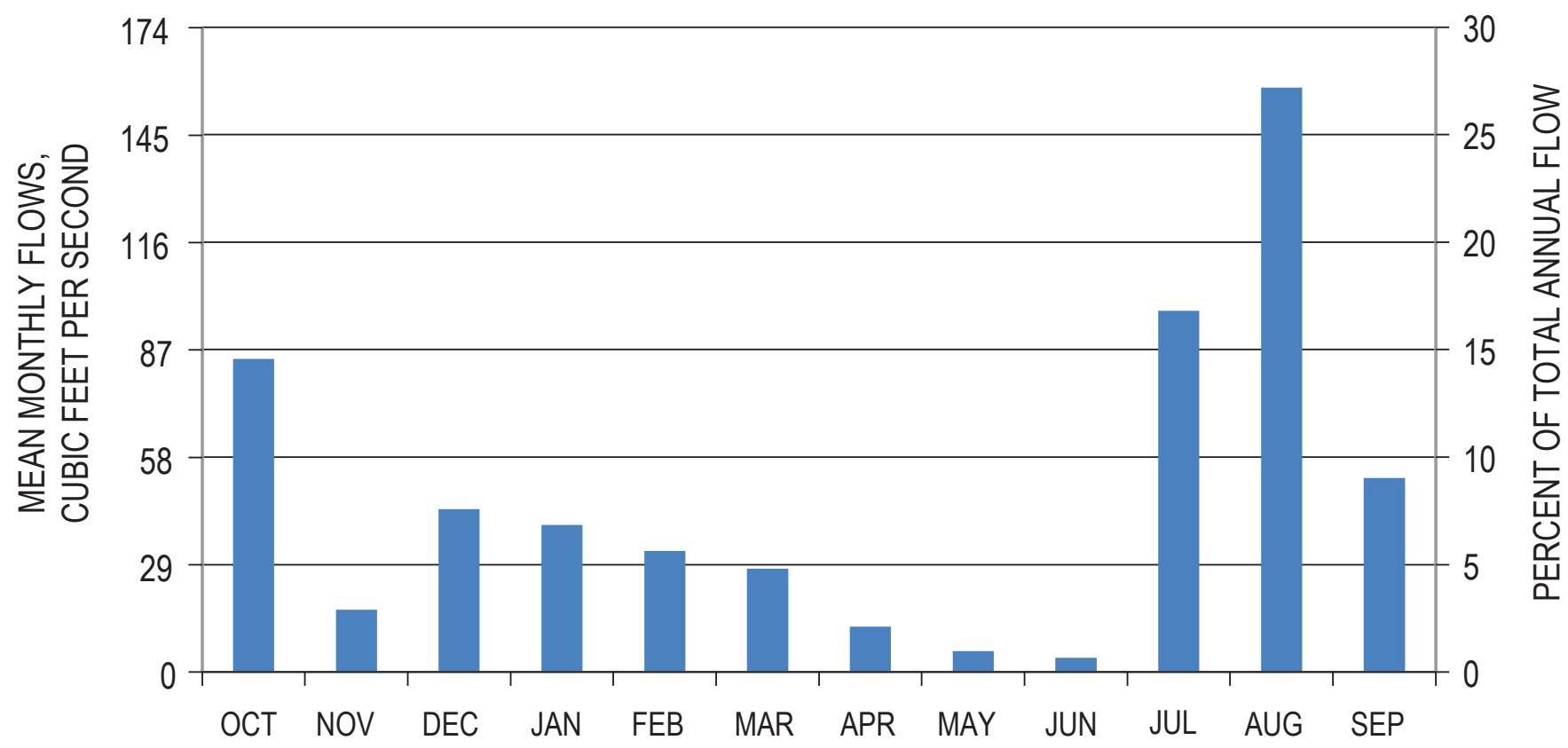

Figure 3. Graph showing seasonal distribution of streamflow at San Pedro River near Tombstone, Arizona (station number 09471550). 
to the lack of spatially extensive historical precipitation data in the large contributing area upstream of the Tombstone gage. Annual base-flow-separated hydrographs are presented in Appendix 1.

To determine the volume of winter base flow, criteria are needed for selecting start dates and end dates ("winter" is used to denote the seasonality of streamflow and not calendar dates). Selection of the end date is straightforward-it is identified as the last day of non-zero mean daily flow, when ET withdrawals equal or exceed base flow. Springtime zero flow occurs every year except 1979 . Likewise, the start date for base-flow calculations in years when the San Pedro River near Tombstone is dry in the fall can be easily determined as the first day of non-zero mean daily flow. For other years, when streamflow is continuous from the summer monsoon through the winter base-flow season, the start date for baseflow calculations requires interpretation. One method is to identify the first date of steadily increasing groundwater discharge in the fall (fig. 4). This represents the date when the average upstream hydraulic gradient reverses from a negative to a positive hydraulic gradient, allowing groundwater to flow into the channel. Storm runoff in October or November obscured this point of minimum streamflow in 1972, 1978, $1979,1982,1984,1986$, and 2001, and for those years no estimate of start date has been made. Instead, base flow for these years was estimated using a linear regression between base flow and 25th-percentile flow (presented below).

Using the start and end date criteria outlined above, and the delta-filter hydrograph separation method, base flow in the San Pedro River near Tombstone varies from 1,220 acre-ft in 1999 to 20,600 acre-ft in 1985 (table 3). Two years, 1979 and 1985 , have anomalously high values. Winter precipitation was above average for both of these years, and the base-flow volume probably reflects a significant amount of short-term

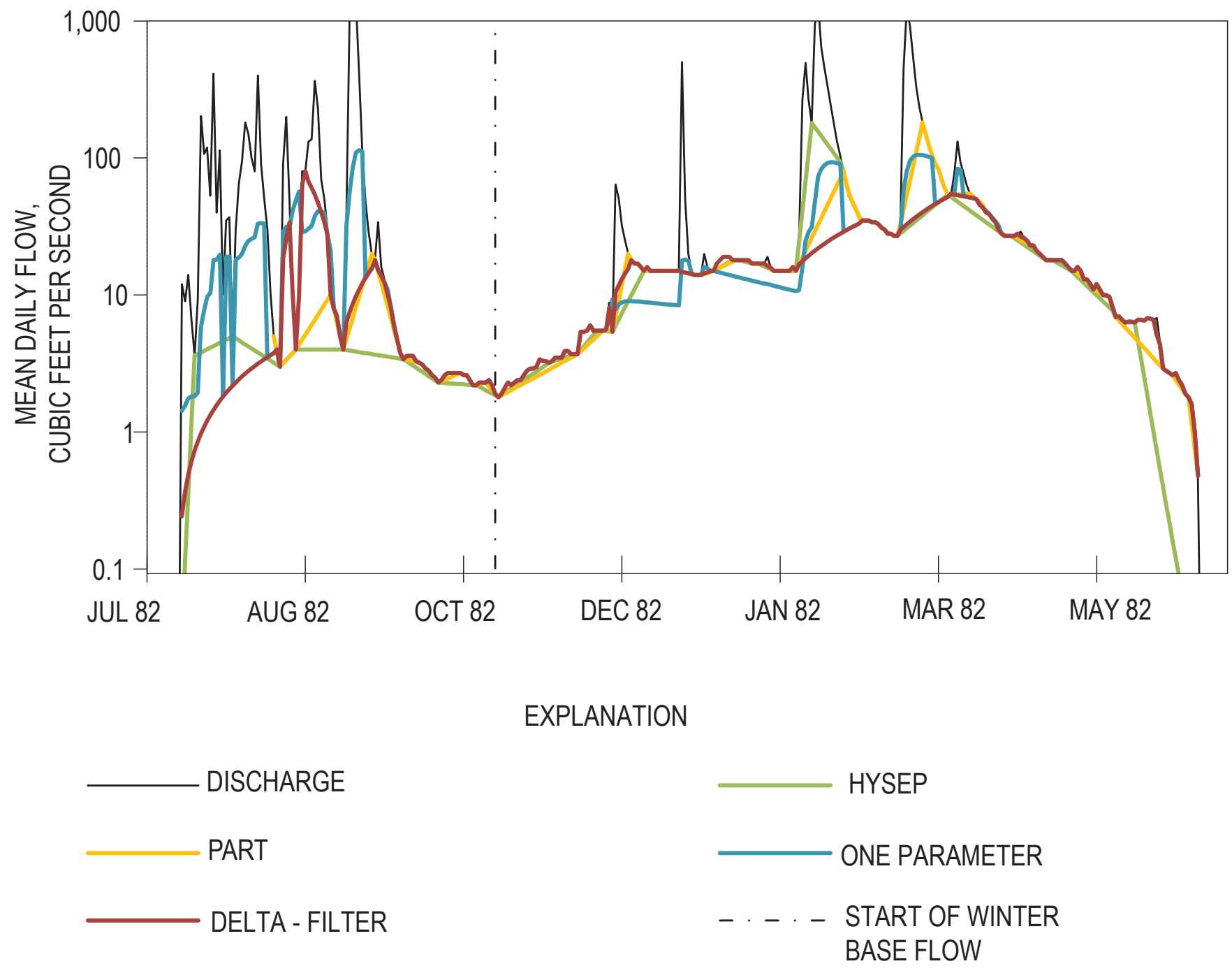

Figure 4. Graph showing comparison of four base-flow separation methods applied to the streamflow record at San Pedro River near Tombstone gage (station number 09471550). The start of winter base flow is identified as the local minimum in the fall, shown as the vertical dashed line. 
storage even after application of the hydrograph separation method. The proportion of base flow to total flow between the annual start date and end date varies from 23 percent in 1979, an El Niño period with associated heavy rainfall, to 100 percent in 2002, 2006, and 2009. In general, winters with greater rainfall are associated with a lower proportion of base flow to total flow. Eighteen of 25 years have a base flow of 94 percent or greater of total winter-flow volume, showing that winter storm runoff is typically a relatively small proportion of total winter streamflow.

Using a different method in which base flow was identified as the ratio of monthly 3-day low flow to total flow, Thomas and Pool (2006) found that base flow at the Charleston gage is on average 82 percent of total flow in winter (November to March), 72 percent in early spring (April to May), 55 percent in late spring (June), and 67 percent in late fall (October) for the period 1931 to 2002. These average values, while in the same range as those calculated for our study, mask the large year-to-year variation in the ratio of base flow to total flow.

To extend the base-flow analysis to years when a start date is not readily obtained or where winter precipitation obscures the base-flow record, flow-duration curves (FDCs) are used. FDCs for the streamflow record at the gaging station near Tombstone typically show a distinct flat profile for percentiles higher than about the 25th percentile, which represents the midwinter steady flow rate (fig. 5). A slope breakpoint is clearly visible at about the 25th percentile in most years, after which lower-percentile mean daily flows increase rapidly. Plotting the FDC mean daily flow values by group - flow during the summer monsoon and flow during the rest of the year-clearly shows that this breakpoint is the division between summer and winter flow and that flow at percentiles higher than the 25th are generally winter/nonmonsoon-influenced flow.

Because the 25th percentile is closely related to winter mean daily flow, it can be used as a surrogate for winter base-flow volume. Use of the 25 th percentile contrasts with the more commonly used 75 th or 90 th percentiles (Smakhtin, 2001) but is necessary given the periods of zero flow at the gaging station near Tombstone - the 90th percentile is nearly always zero and the 75th percentile is often so. A linear regression model, calculated using ordinary least squares, is used to estimate base flow in years when hydrograph separation is not feasible (fig. 6). These base-flow values are denoted by italics in table 3.

If the 25th percentile mean daily flow represents groundwater discharge to the river, integrating this value over an entire year provides the total volume of groundwater that contributes to both streamflow and riparian ET. Using the values from table 3 , this volume is $11,580,7,090$, and 10,860 acre- $\mathrm{ft}$ annually for the early, late, and combined period of record, respectively. These values are about the same magnitude as the range of annual ET, 9,600 to 12,055 acre-ft, estimated by Scott and others (2006). This suggests that, in the absence of summer storm runoff, it is possible that all groundwater discharging as streamflow could instead be removed as ET.

\section{Methods to Identify Sources of Base Flow}

Base flow in the San Pedro River is a combination of regional groundwater and storm runoff that is stored in the near-stream alluvial aquifer as "alluvial groundwater". Alluvial groundwater has residence times in the subsurface from days to months, whereas regional groundwater has residence times on the order of decades, centuries, or longer. The relative contributions of each of these to base flow and changes in each over time, are evaluated through further inspection of the stream hydrograph and analysis of environmental isotope tracers.

\section{Hydrograph Characteristics}

Drier-than-average summer monsoons and low winter rainfall in 2002, 2003, and 2004 provide an opportunity to look at the regional groundwater contribution to streamflow independently from alluvial groundwater. Streamflow at the Tombstone gage goes to zero quickly at the end of the monsoon (September) in each of these years and does not return until December (fig. 7). We can assume that alluvial-groundwater contributions to streamflow are minimal during these years and that the source of winter streamflow is primarily regional groundwater. Average base flow is about 1,680 acre- $\mathrm{ft}$ during this period (the area under the dotted line curve in fig. 7). If this value is assumed to represent regional groundwater contributions to base flow for the period 1996 to 2009, alluvial groundwater contributions to base flow are the difference between this value and the total winter base flow and range from 0 acre-ft (in 1999 and 2004) to 2,730 acre-ft (in 1998) or from 0 to 62 percent of total base flow.

Comparing this same average base-flow value, 1,680 acre-ft, to measured base flow in 1999 (fig. 8), however, shows that the minimum regional groundwater contribution may be somewhat less - total base flow in 1999 is just 1,220 acre-ft, even though the total summer monsoon flow was 6,530 acre- $\mathrm{ft}$ (compared to 4,070,6,910, and 7,710 acre-ft of monsoon flow in 2003, 2004, and 2005, respectively). The difference between 1999 and the 2002 to 2004 period is likely because of small variations in the timing of summer runoff and winter rainfall —in 1999, monsoon runoff stopped earlier in the summer and winter rainfall was less than the other years. This suggests that, even following the relatively dry summers of 2002 through 2004, some component of alluvial groundwater may be present in base flow.

The average 1,680 acre- $\mathrm{ft}$ of base flow from regional groundwater observed for the 2003 to 2005 period occurs later than base flow in a dry year, 1981, during the early period of the record (fig. 8), in agreement with the results of Thomas and Pool (2006), who found that 60 percent of the decrease in annual base flow from 1931 to 2002 was from September to November. Streamflow in 1981 begins a full month earlier, in late October, than it does in 2003 to 2005, when it does not begin until late November. The rate of 
Table 3. Base-flow statistics for San Pedro River near Tombstone (USGS station number 09471550).

[cfs, cubic feet per second; $\mathrm{C}_{50}$, median value. Bold, Continuous flow through fall months; date estimated as first date of continuously increasing streamflow. Italic, Base flow could not be estimated from hydrograph; a linear regression model between 25th percentile and mean daily flow was used (fig. 6). NA, Start date could not be estimated, because storm runoff events obscured start of base flow. 1979 and 1982, flow begins on 10/21 with a storm event in both years, not used. --, Flow was continuous through spring 1979; base flow as a percent of total flow between start and end dates is calculated assuming an end date of $7 / 1]$

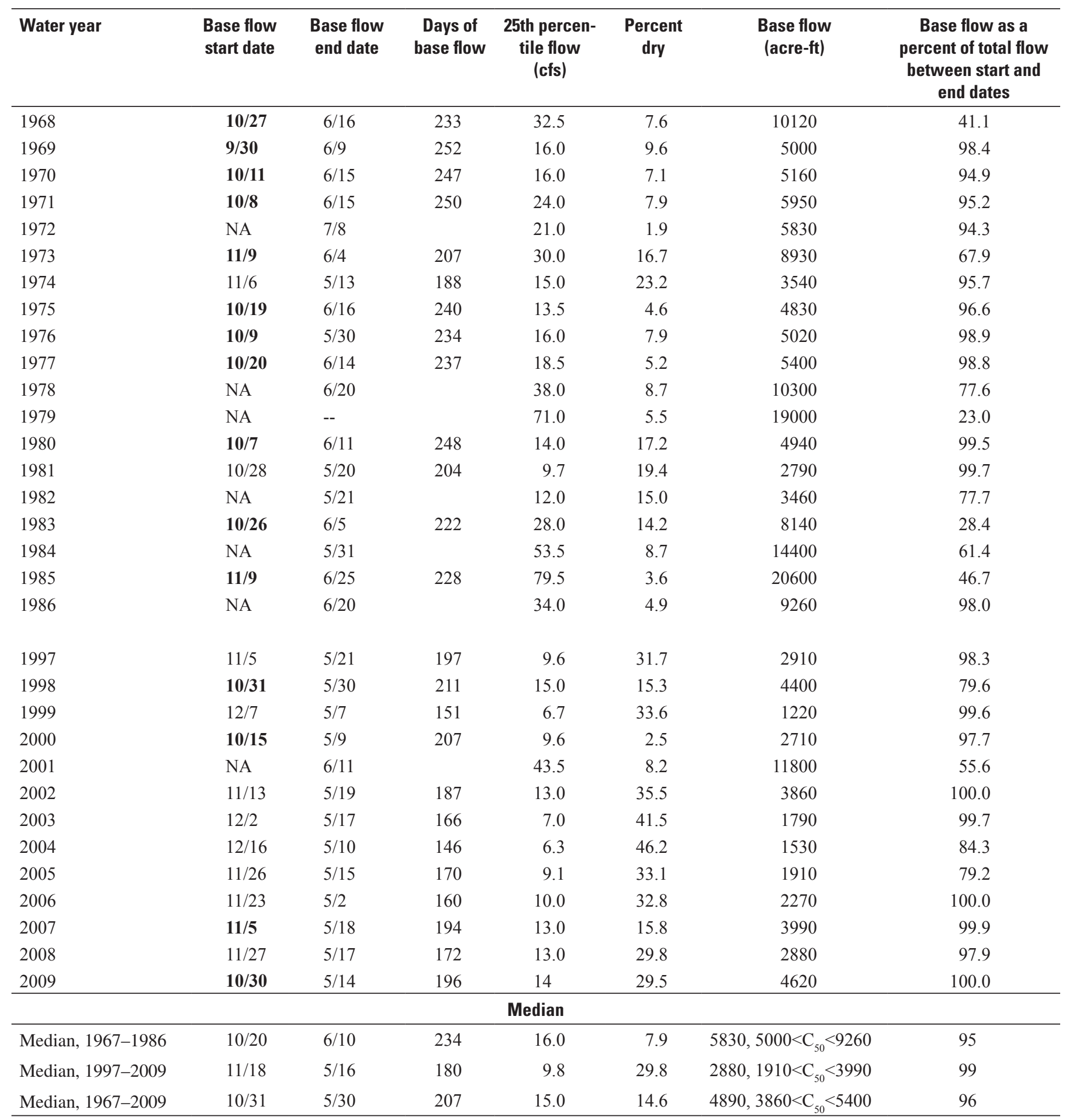




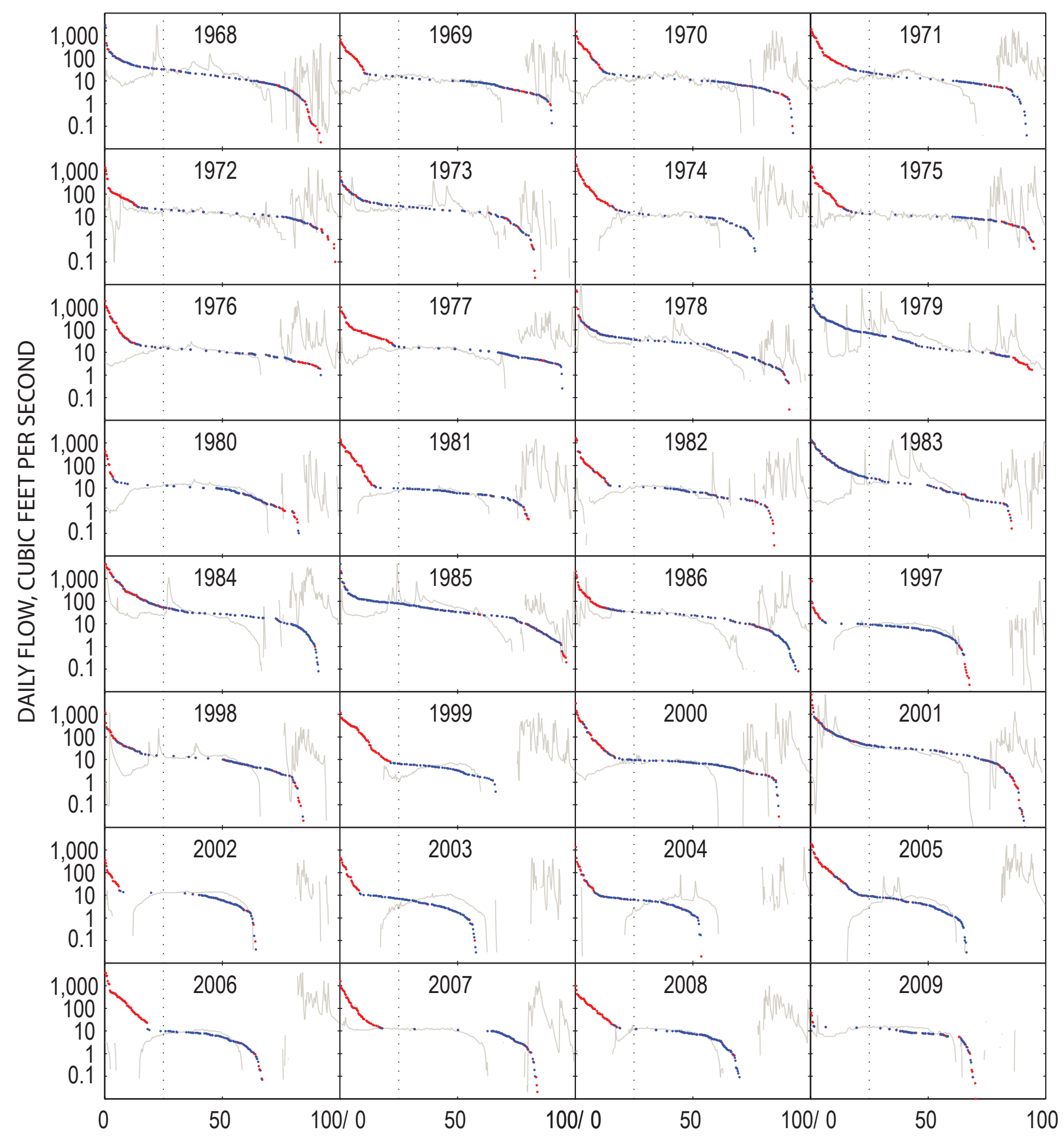

Percent of year since October 1 (gray line)/Percent of time that a given flow is exceeded (red/blue dots)

Figure 5. Flow duration curves and stream hydrographs at San Pedro River near Tombstone (station number 09471550) for 1968-1986 and 1997-2009. Blue points indicate streamflow during the months of November through June; red points are July through October. Vertical dotted line shows the 25th percentile. 
increase in discharge is also higher during the earlier period, reaching the midwinter steady flow rate by early January and lasting until mid-March. In contrast, the increase in discharge during the latter period (shown by the dotted line in fig. 8) is more gradual, and the midwinter steady flow rate is much shorter ( $\sim$ two weeks) in duration. Following the midwinter steady flow rate, both the early record and the late record show discharge declining at a similar rate as ET withdrawals increase and cause losing conditions.

One possible explanation for the later start date of flow during the later period of record and, in particular, the difference between the 1981 and 2002 to 2004 hydrographs, is the date of the first freezing temperature in the fall. The first hard freeze (below about $-5^{\circ} \mathrm{C}$ ) along the river causes leaf mortality and a large reduction in ET almost immediately and allows gaining conditions to be established in the stream channel (Goodrich and others, 2000). Records from the National Weather Service cooperative observer station (NWS station 028619) in the city of Tombstone, AZ, indicate that the first low temperature in fall 1980 occurred on October 16, and flow resumed soon afterwards (fig. 8). In fall 2002, 2003, and 2004, the first low temperatures occurred on December 4, November

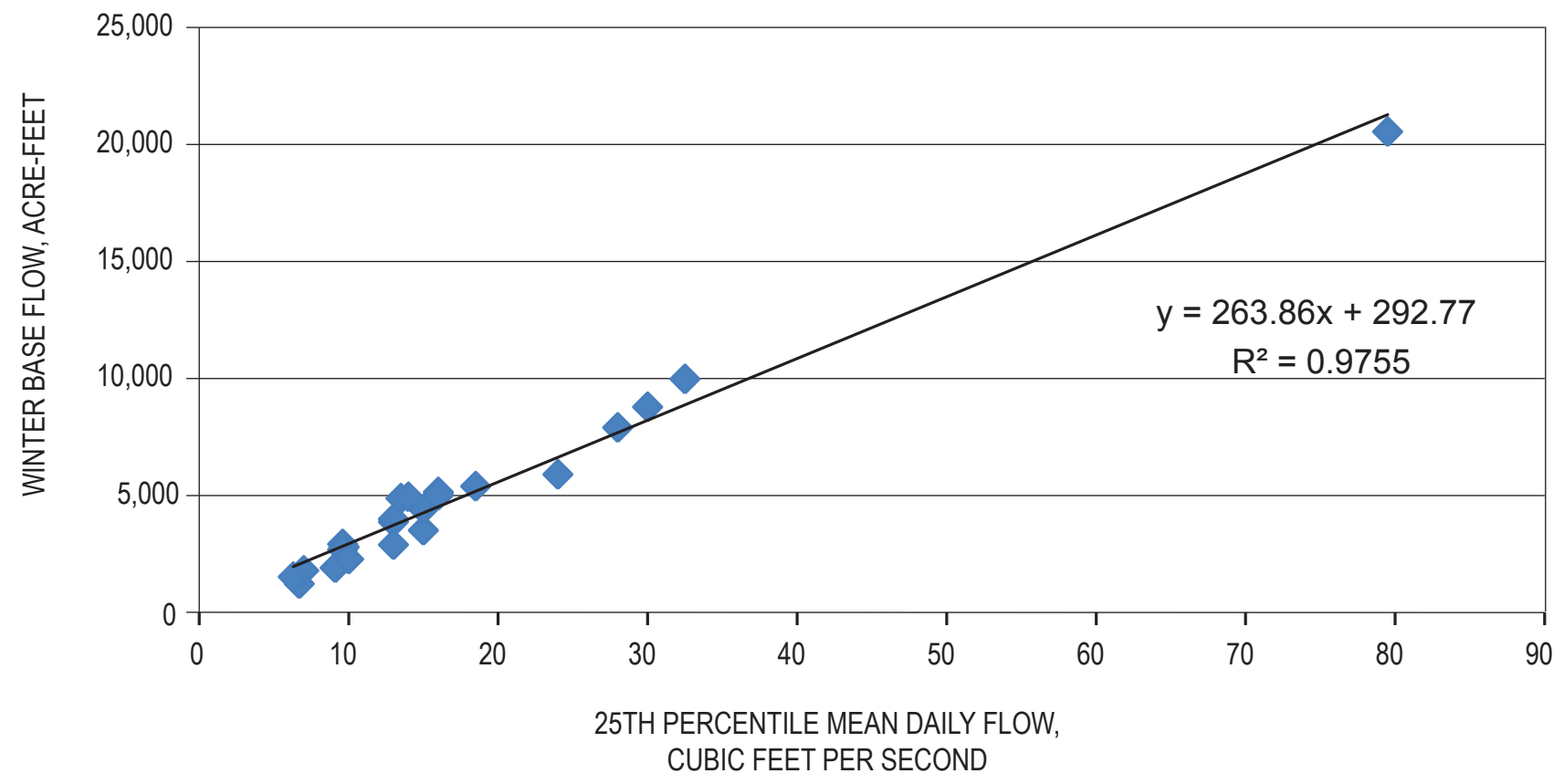

Figure 6. Scatter plot of winter base-flow volume vs. flow percentile.

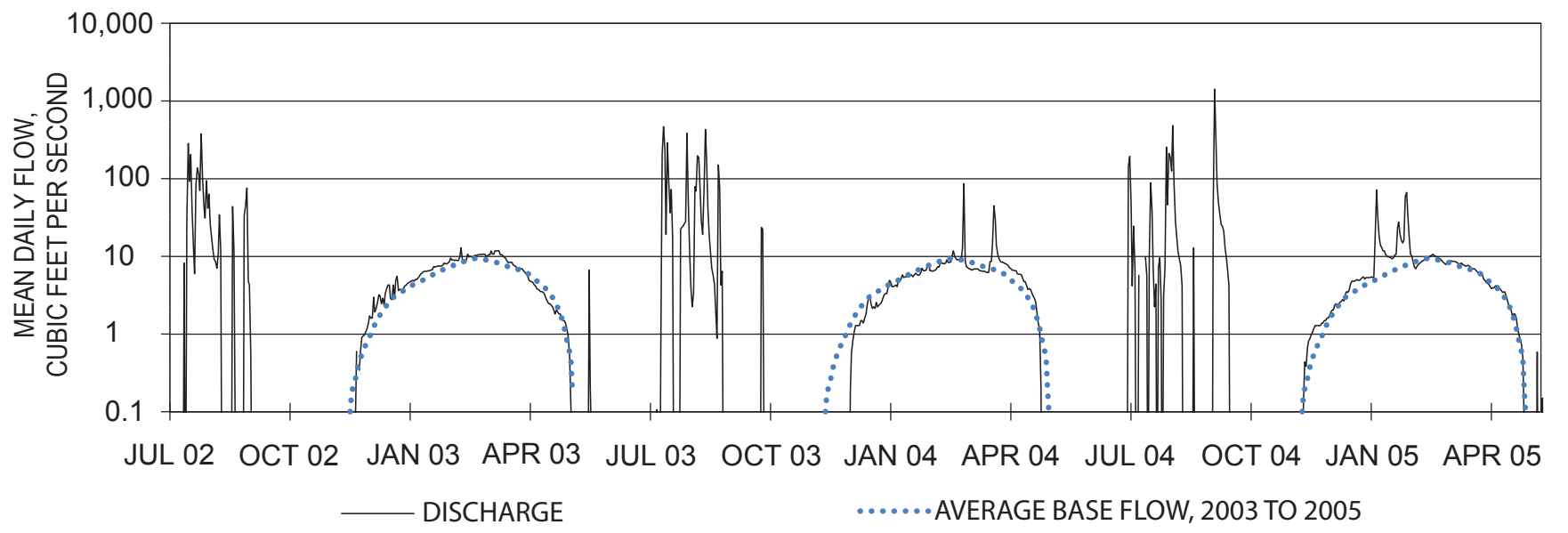

Figure 7. Streamflow at San Pedro River near Tombstone (station number 09471550) September 2002 to May 2005. Blue dots indicate average base flow contribution to streamflow. 
25 , and November 2, respectively, and flow resumed later in these years. Lack of a clear relation between recorded temperature at Tombstone and temperature along the river corridor and absence of long-term records of temperature along the river corridor, however, preclude definitive conclusions about the effect of temperature on winter base flow.

\section{Environmental Isotopes}

Environmental isotope ratios such as hydrogen $\left(\delta^{2} \mathrm{H} / \delta^{1} \mathrm{H}\right)$ and oxygen $\left(\delta^{18} \mathrm{O} / \delta^{16} \mathrm{O}\right)$ provide a further means to evaluate regional and alluvial groundwater sources. The isotopic composition of rainfall is influenced by the temperature at which it forms; higher altitude rainfall is generally more depleted in heavier isotopes than lower altitude rainfall. Because of this, orographic uplift of rain-forming clouds causes isotopic fractionation, and higher elevations generally receive more isotopically depleted rainfall. This effect occurs even where topographic relief is minor (Clark and Fritz, 1997) and results in variations in groundwater isotopic composition in the San Pedro Basin that correlate with recharge source-area elevation (Pool and Coes, 1999). Once precipitation leaves the atmosphere and becomes runoff and (or) recharge, the isotopic signature generally does not change. The isotopic composition of streamflow reflects its source waters and, if two or more sources have sufficiently different signatures, the amount of each in a composite sample may be estimated.

In this report, we use the mass-balance method to evaluate the relative contribution of regional groundwater and alluvial groundwater to base flow. A simple linear relation describes the conservative mixing of two end members,

$$
\frac{Q_{b g w}}{Q_{t}}=\frac{\delta_{t}-\delta_{a g w}}{\delta_{r g w}-\delta_{a g w}}
$$

where $\mathrm{Q}$ refers to discharge, $\delta$ is isotope composition, and the subscripts $t, a g w$, and $r g w$ refer to total flow, alluvial groundwater, and regional groundwater, respectively. This relation is used with a single constituent isotope, either hydrogen or oxygen, and may be calculated independently for each (for end members that fall on the meteoric water line (MWL), however, the two isotopes will provide the same result). The end members for the mixing model are regional groundwater and alluvial groundwater.

Beginning fall 1999, water samples of in-stream flow have been collected at approximately monthly intervals at five sampling sites on the San Pedro River and one site on the Babocomari River. These samples are analyzed for stable hydrogen and oxygen isotope ratios at the USGS Reston Stable Isotope Laboratory. Hydrogen (deuterium) activity is measured using a hydrogen equilibration technique (Révész and others, 2008a). Oxygen activity is measured using an automated $\mathrm{CO}_{2}$ equilibration technique (Révész and others, 2008b). Values are reported in per mill units (\%o) relative to Vienna Standard Mean Ocean Water. Measurement uncertainties (2 standard deviations) for oxygen and hydrogen are $0.2 \%$ and $2 \%$, respectively.

Thirty-six streamflow samples collected at the Tombstone gage plot along a line in a $\delta^{18} \mathrm{O}-\delta^{2} \mathrm{H}$ graph (fig. 9) and have a slope that departs from the meteoric water line, which indicates evaporative enrichment (Gat, 1996). Evaporative fractionation causes the isotopic composition of water to become enriched as lighter isotopes preferentially evaporate. The most depleted streamflow at the Charleston gage, the Tombstone gage, and the Babocomari gage occurs at the beginning of most winters (fig. 10). The composition of Tombstone gage samples is either between the Charleston and Babocomari River gage samples or more enriched than both. Over the course of a winter, samples at all sites become more enriched, but the rate of change is greatest at the Tombstone gage. The most enriched samples are collected at the end of the winter
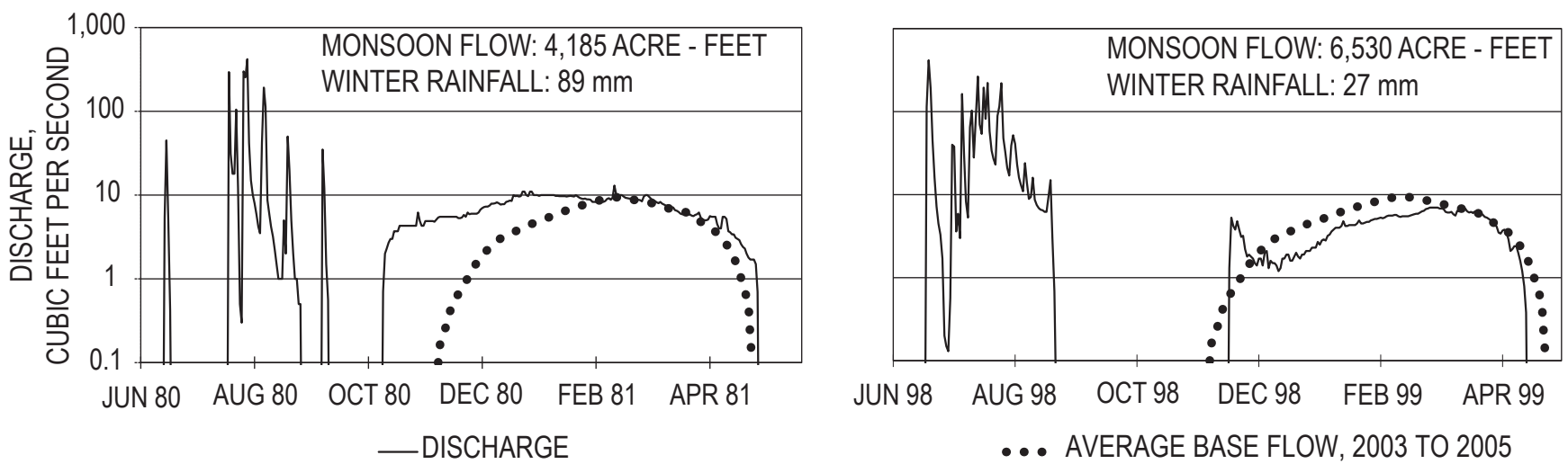

Figure 8. Streamflow at San Pedro River near Tombstone (station number 09471550) for 1980 to 1981, and 1998 to 1999, showing comparison of the average base flow contribution to streamflow, based on the 2003 to 2005 record. 
base-flow season. Although the evaporative enrichment process applies only to water evaporated from the river and from soil water directly and does not occur through transpiration (Gat, 1996), the rate of evaporation and therefore fractionation likely increases with the onset of ET in spring as discharge decreases and air and water temperatures rise. By projecting the best-fit line of the enriched samples to the intersection with the meteoric water line, the original pre-evaporative composition of Tombstone winter base flow may be estimated as $-56.75 \%$ o $\delta^{18} \mathrm{O}$ and $-8.1 \%$ o $\delta^{2} \mathrm{H}$ (fig. 9).

This isotopic composition of pre-evaporative Tombstone base flow is more enriched than most regional groundwater west of the San Pedro River and similar to regional groundwater east of the river (fig. 11). Regional groundwater composition is spatially well defined at 106 locations by samples collected at wells and springs during previous studies (Pool and Coes, 1999; Wahi, 2005; Goodrich and others,
2004). Groundwater recharged at high elevations in the Huachuca Mountains has the most depleted isotopic composition in the basin. The average isotopic composition of this Sierra Vista-area groundwater (gray-shaded area in fig. 11) is $-65.5 \pm 3.2 \%$ o $\delta^{18} \mathrm{O}$ and $-9.31 \pm 0.4 \%$ o $\delta^{2} \mathrm{H}$, whereas the average composition of all sites west of the river (excluding alluvial aquifer wells) is $-59.8 \pm 5.6 \% \delta^{18} \mathrm{O}$ and $-8.5 \pm 0.82 \%{ }^{2} \mathrm{H}$. This isotopically depleted region corresponds with the steepest hydraulic gradients in the basin (Schmerge, 2009) and is generally believed to contribute a substantial proportion of the regional groundwater contribution of winter base flow (Pool and Coes, 1999; Baillie and others, 2007). To account for the isotopic signature of winter base flow at Tombstone, however, one or more other, more enriched groundwater sources must also contribute.

Potential isotopically enriched regional groundwater sources of Tombstone winter base flow are subflow from the

\section{OXYGEN ISOTOPE RATIO, PER MILL}

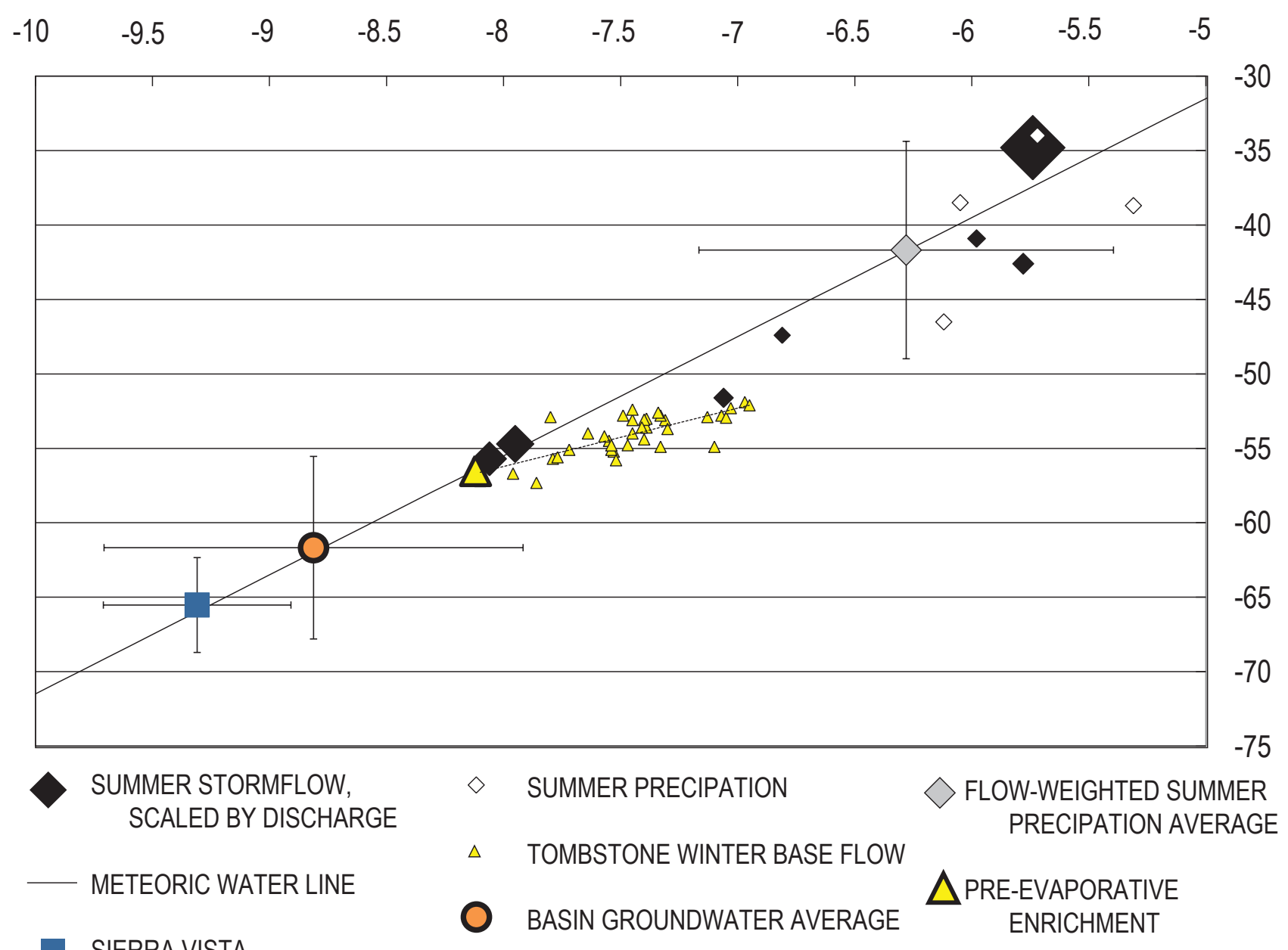

Figure 9. Graph showing mean hydrogen and oxygen ratios at selected sites along and near the San Pedro River. Winter base flow is the average of samples collected from December to March at discharge rates less than $20 \mathrm{cfs}$. Summer flow is the discharge-weighted average of samples collected from July to September. Horizontal and vertical error bars show \pm 1 standard deviation of the mean. 
south and groundwater recharged in the lower-elevation Mule Mountains east of the river, subflow channeled between the Bronco and Babocomari Hills west of the river, and subflow from the Walnut Gulch watershed east of the river (fig. 1). Regional groundwater samples collected at 12 sites east of the river (excluding alluvial aquifer wells) have an average composition of $-55.5 \pm 3.2 \% 0 \delta^{18} \mathrm{O}$ and $-7.90 \pm .46 \%{ }^{2} \mathrm{H}$. In the lower part of the basin, samples collected at Monitor Well 7, representative of subflow between the Bronco and Babocomari Hills west of the river, and at four sites in Walnut Gulch, east of the river, all have compositions similar to or more enriched than Tombstone base flow. Because these values, together with the isotopic composition of Sierra Vista-area groundwater, bracket the composition of Tombstone base flow, a significant amount of inflow of groundwater from the south, east, and north could account for the isotopic signature at Tombstone.

A second potential contributor of isotopically enriched groundwater to Tombstone base flow is summer stormflow that is stored as alluvial groundwater when elevated river stage causes infiltration into stream channel alluvium. It typically is more enriched than winter base flow, but storms may also produce lighter-composition streamflow, as well. In some years, such as 2000 , both isotopically light and heavy precipitation (and therefore streamflow) occur during the same summer (fig. 10). Similar to regional groundwater, this inconsistent signature makes identification of an average precipitation and
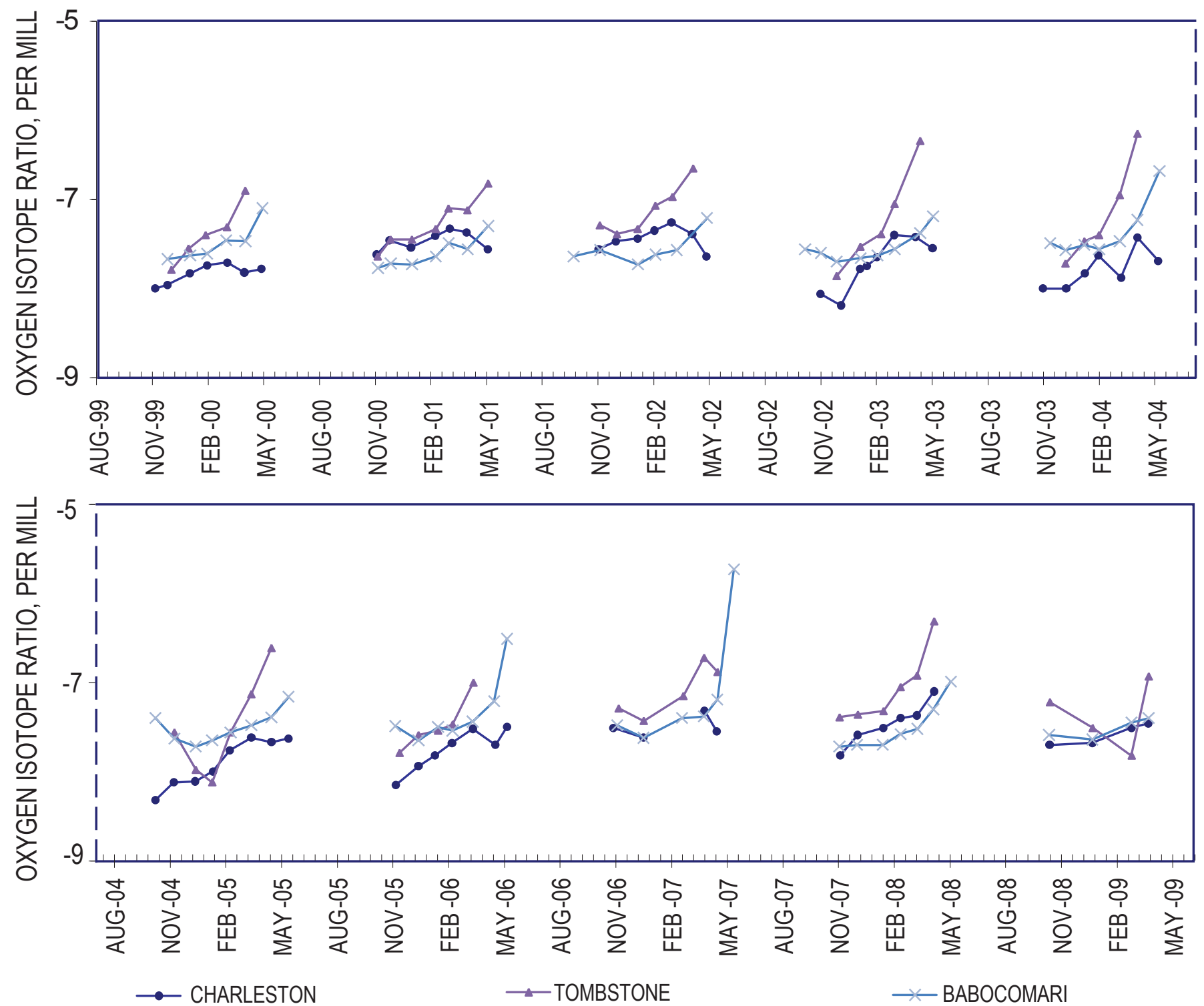

Figure 10. Graph showing hydrogen isotope samples collected during winter at the Charleston, Tombstone, and Babocomari River gages. Dashed boundary denotes continuous data. 


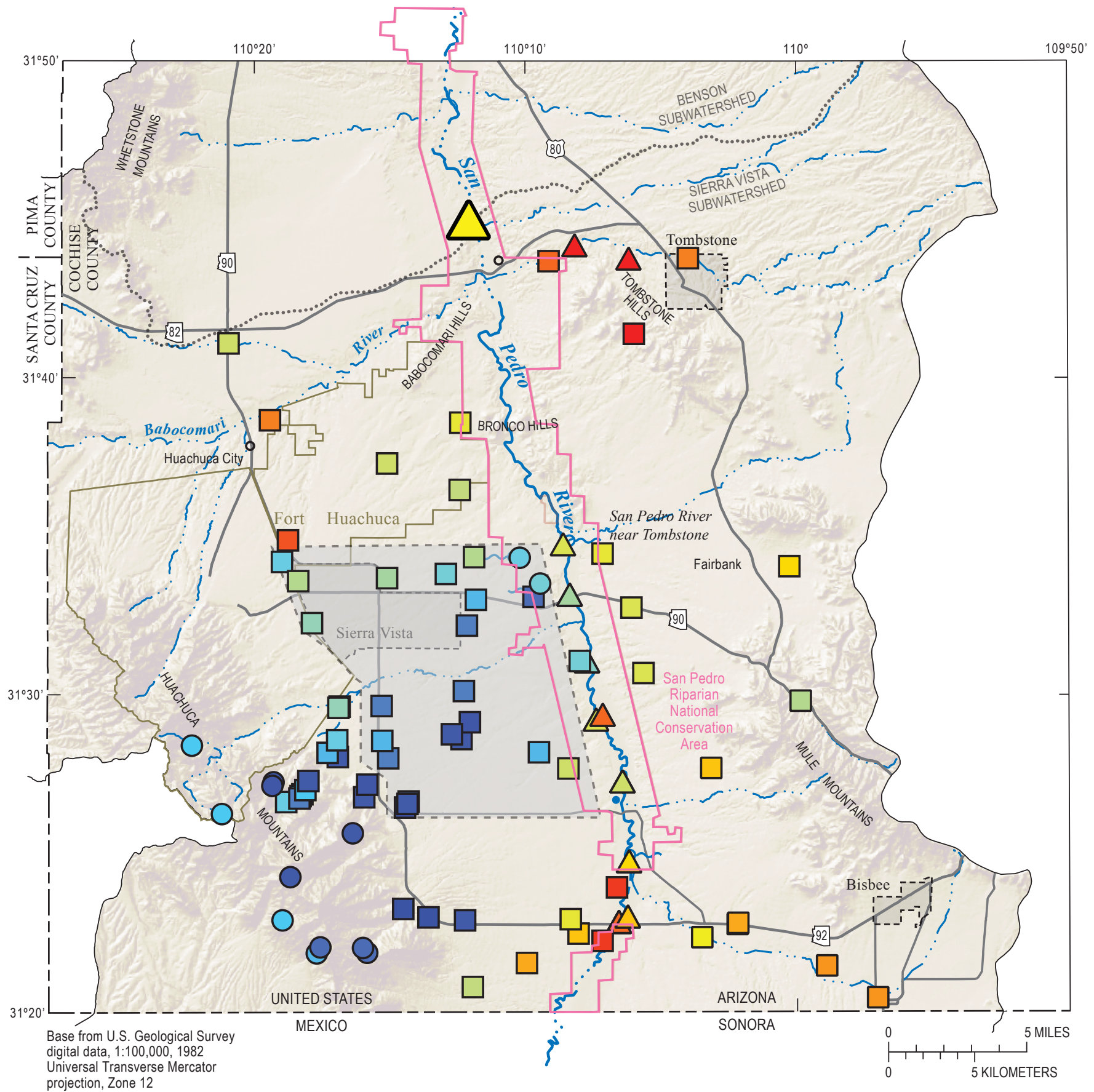

Explanation

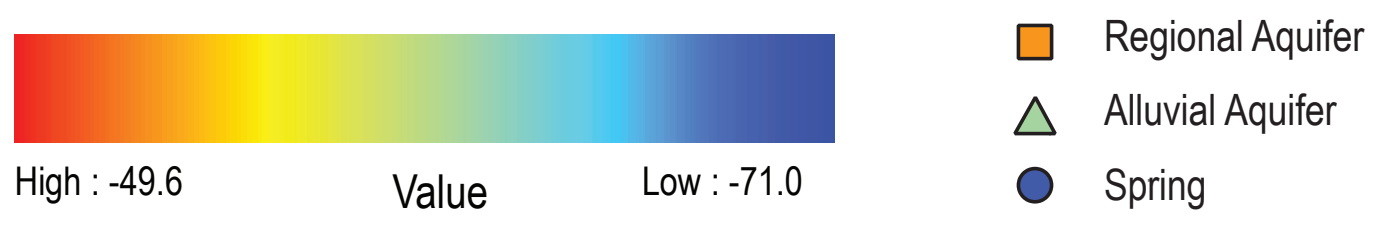

Figure 11. Map showing $\delta^{2} \mathrm{H}$ concentrations at regional and alluvial groundwater sampling sites. Shaded region shows the region for which the Sierra Vista-area isotopic composition is calculated. 
stormflow signature difficult. Samples collected during periods of high flow, when storage of runoff in the alluvial aquifer is highest, have a greater impact on the average stormflow composition than samples collected at lower discharge rates. Therefore, a discharge-weighted average value is more representative than a simple average. The average composition of alluvial groundwater from eight streamflow samples, collected at the Charleston gage during runoff events (discharge greater than $25 \mathrm{cfs}$ ) in July, August, and September, and four summer rainfall samples is $-41.7 \pm 6.3 \%{ }_{0} \delta^{18} \mathrm{O}$ and $-7.30 \pm 0.89 \% \delta^{2} \mathrm{H}$ (fig. 9). Discharge at the Charleston gage while samples were collected varied from 25 to $404 \mathrm{cfs}$. Although a number of samples have been analyzed from wells located in the alluvial aquifer, these are excluded from the average value because they represent an unknown mixture of regional and alluvial groundwater, whereas the stormflow and precipitation samples represent only water derived from summer stormflow.

Because of the uncertainty in determining the isotopic composition of regional groundwater that contributes to base flow, described above, a simple average of all regional groundwater samples is used in the mixing model analysis. Otherwise, detailed knowledge of the isotopic composition and discharge rates of specific zones of groundwater discharge to the river would be needed to fully define this end member. The average value is believed to be representative because hydraulic gradients indicate that groundwater flow throughout the basin is toward the river (Schmerge, 2009), and sampling bias has resulted in more samples collected west of the river, where hydraulic gradient is highest. This results in the region west of the river having a greater influence on the average value of the isotopic composition of regional groundwater.

Using the isotopic compositions for the groundwater end members and winter base flow described above, the average proportion of regional groundwater to total winter base flow at the Tombstone gage is 74 percent. Alluvial groundwater supplies the other 26 percent. Considering uncertainty in the average values used for the source groundwater and the mixed water at the Tombstone gage (Phillips and Gregg, 2001), the 95 percent confidence interval is 64 percent to 84 percent. Applying this average composition of winter base flow at the Tombstone gage to the median value of winter base flow calculated during the later period of record (2,880 acre-ft, table 3), the median amount of annual regional groundwater discharged as base flow from 2000 to 2009 is 2,130 acre-ft.

Identifying a single value of regional groundwater contribution to base flow at the Tombstone gage oversimplifies the complexity of a large, dynamic, natural system. The large year-to-year variation in winter base-flow volume makes identification of an average composition difficult, and any given year may have winter base flow that differs significantly from that average. Reasonable estimates of the groundwater contribution to base flow can be made only because a large number of samples have been collected over a 10 -yr period, and these estimates apply only to the period for which isotope data are available. Changes in infiltration rates (such as those caused by channel incision), seasonality of rainfall, and ET would all potentially cause regional and alluvial groundwater proportions to be different in the past.

\section{Trend in Base Flow}

Summary statistics of the different base-flow metrics show differences between the early period of record, 1967 to 1986, and the late period, 1996 to 2009 (table 3). The median is a more useful indicator of central tendency in this case, because it is not skewed by the anomalously wet winters in 1979 and 1985. Base flow during the late period of record is shorter in duration and at a lower discharge than the early period. The median number of days of winter base flow has decreased from 234 to 180 , and the period of zero flow during the calendar year has increased from 7.9 percent to 29.8 percent. Total base-flow volume has decreased about 51 percent, from a median value of 5,830 acre-ft/yr for the early period to 2,880 acre-ft/yr for the later period. Average base flow for the entire period of record is 4,890 acre-ft/yr.

The decrease in base flow is most pronounced during late fall/early winter and is apparent whether using the delta-filter method described above to separate base flow from total flow or the 3-day monthly low-flow method (table 4). The largest decreases, 80 percent and 51 percent (calculated from base flow-separated streamflow), are in November and December, respectively. Somewhat smaller decreases of about 40 percent are observed in January through April. Possible causes for this decrease in base flow are a decrease in precipitation and, therefore, reduced runoff and storage in the alluvial aquifer, reduced inflow of regional groundwater, or increased ET.

\section{Variation in Base Flow Caused by Precipitation}

One apparent reason for the decline in streamflow from the early period of record to the late period is a decline in precipitation. While the average annual rainfall does not differ significantly-from $348 \mathrm{~mm}$ for the early period to $330 \mathrm{~mm}$ for the late period - the decline occurs in the months most likely to influence winter base flow, September and October (fig. 12). These two months exhibit the largest decrease from the early period to the late period. This lack of late- and postsummer rainfall has a direct effect on the amount of desaturation of the alluvial aquifer caused by ET and, therefore, on the date that flow resumes at the Tombstone gage in late fall/early winter, which directly influences winter base-flow volume. Rainfall amounts in September and October for the late period are close to the long-term average (1931 to 2009), while winter precipitation is lower than average (fig. 12). Rainfall during the early period of record in the months from September to November and from January to March are higher than the long-term average, and this is likely reflected in the streamflow record at the San Pedro River near Tombstone. A comparison of monthly rainfall for each year shows that for 
Table 4. Median of the mean daily flow by month for the periods from 1968 to 1986 and from 1997 to 2009 for the San Pedro River near Tombstone.

[Base flow, measured streamflow with stormflow removed, as described in discussion; low flow, lowest 3-day average of mean daily flow in a given month; $\mathrm{C}_{50}$, median value for which half of the data points are above and half are below; C.I., confidence interval]

\begin{tabular}{|c|c|c|c|c|c|c|c|}
\hline \multirow{2}{*}{$\begin{array}{c}\text { Period } \\
\text { (water year) }\end{array}$} & \multirow{2}{*}{ Method } & \multicolumn{2}{|c|}{ November } & \multicolumn{2}{|c|}{ December } & \multicolumn{2}{|c|}{ January } \\
\hline & & Median & C.I. ${ }^{1}$ & Median & C.I. ${ }^{1}$ & Median & C.I. ${ }^{1}$ \\
\hline 1968 to 1986 & Base flow & 10.6 & $7.8 \leq \mathrm{C}_{50} \leq 18.5$ & 14.2 & $12.6 \leq \mathrm{C}_{50} \leq 19.5$ & 16.8 & $14.4 \leq \mathrm{C}_{50} \leq 26.4$ \\
\hline 1997 to 2009 & Base flow & 2.2 & $0.1 \leq \mathrm{C}_{50} \leq 4.2$ & 6.9 & $1.9 \leq \mathrm{C}_{50} \leq 12.6$ & 10.1 & $6.5 \leq \mathrm{C}_{50} \leq 12.8$ \\
\hline \multirow{2}{*}{$\begin{array}{c}\text { Period } \\
\text { (water year) }\end{array}$} & \multirow{2}{*}{ Method } & \multicolumn{2}{|c|}{ February } & \multicolumn{2}{|c|}{ March } & \multicolumn{2}{|c|}{ April } \\
\hline & & Median & C.I. ${ }^{1}$ & Median & C.I. ${ }^{1}$ & Median & C.I. ${ }^{1}$ \\
\hline 1968 to 1986 & Base flow & 17.7 & $16.0 \leq \mathrm{C}_{50} \leq 30.9$ & 15.8 & $13.6 \leq \mathrm{C}_{50} \leq 31.1$ & 10.8 & $9.5 \leq \mathrm{C}_{50} \leq 18.7$ \\
\hline 1997 to 2009 & Low flow & 0.0 & $0.0 \leq \mathrm{C}_{50} \leq 1.9$ & 5.2 & $0.8 \leq \mathrm{C}_{50} \leq 6.1$ & 7.7 & $2.8 \leq \mathrm{C}_{50} \leq 11.0$ \\
\hline
\end{tabular}

\footnotetext{
${ }^{1}$ Confidence interval is a nonparametric estimate calculated using a binomial distribution table, after Helsel and Hirsch (2002). For the period 1968 to 1986, it is the 93.6 percent confidence interval $(\mathrm{n}=19)$; for the period 1997 to 2009 , it is the 90.8 percent confidence interval $(\mathrm{n}=13)$.
}

the early period of record significant winter rainfall occurred primarily in the months of October, December, and January (fig. 13). This figure also highlights the lack of winter precipitation during the late period. Between 1968 and 1986, rainfall of $40 \mathrm{~mm}$ or greater was recorded in a total of 20 months between October and March. Between 1997 and 2009, only 5 months have had $40 \mathrm{~mm}$ of rainfall, and none of these have occurred since 2001.

To evaluate the importance of factors other than rainfall on the volume of annual winter base flow, the relation between rainfall and streamflow must be quantified. Linear regression using ordinary least squares is a commonly used technique that assumes that the residuals (measured value minus predicted value) are homoscedastic (have constant variance), independent, and normally distributed. These assumptions, while not prohibitive, often do not hold true for streamflow data (Helsel and Hirsch, 2002). A nonparametric alternative to linear regression that makes no assumptions about the underlying distribution is Locally Weighted Scatterplot Smoothing, or LOWESS, which will be used here. This smoothing algorithm involves fitting a weighted least-squares regression to subsets of the data. Within each subset, points that are farther from the center in either the $\mathrm{x}$ or $\mathrm{y}$ direction receive less weight. In contrast, ordinary least squares places greater emphasis on minimizing large residuals, caused by points that plot away from the center of the data. LOWESS regression results in a non-linear line that more closely fits the central tendency of the data and is less influenced by outlying data, compared to linear regression. A LOWESS regression may be implemented either as a simple regression, with a single explanatory variable, or as a multiple regression, with two or more explanatory variables.

Ideally, the explanatory variables in the regression analysis are independent of the dependent variable. Because the streamflow record exhibits autocorrelation (that is, streamflow on a given day can be at least partially predicted by streamflow on previous days), it cannot be an independent predictive variable for itself. Because of this, rainfall depth is a better independent variable. During the summer months, however, rainfall is highly variable in space, and the record from a single gage, or even several gages, does not adequately represent the watershed. Therefore, summer streamflow is used as a surrogate for effective summer rainfall across the Subwatershed. Because ET withdraws more water than is supplied by base flow in summer, all summer streamflow at the Tombstone gaging station is the result of summer rainfall only.

Winter rainfall is a second explanatory variable for winter base flow. Direct runoff from winter storms is usually small, but several large storms in the early 1980s are an exception. Although the delta-filter base-flow-separation method removes small stormflow peaks from the base-flow record, long duration, widespread storms are more difficult to separate from groundwater contributions to base flow. During these periods, 


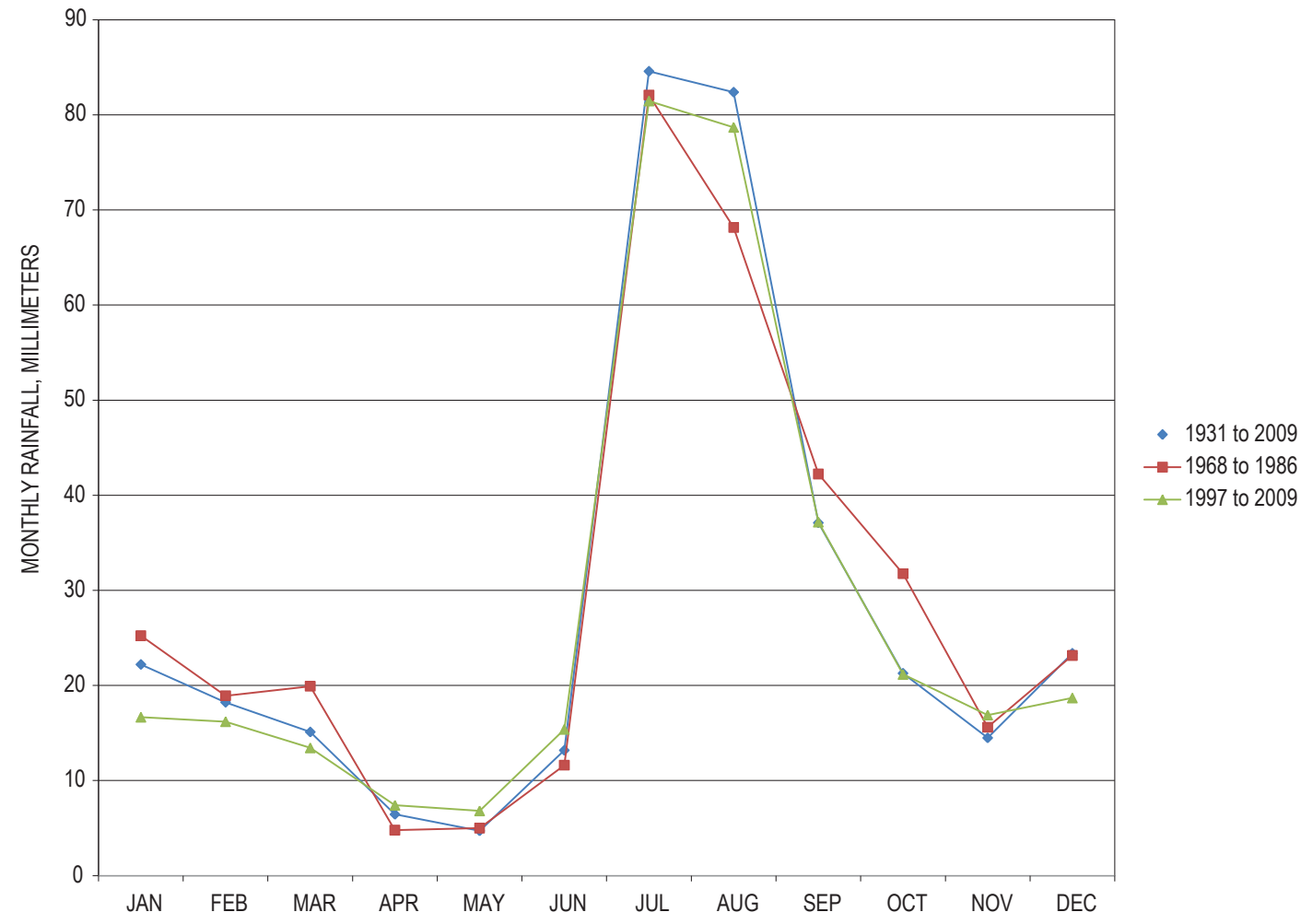

Figure 12. Graph showing average monthly precipitation measured at Tombstone (NWS Coop ID 028619) from 1931 to 2009, and for data subsets from 1968 to 1986 and 1997 to 2009.

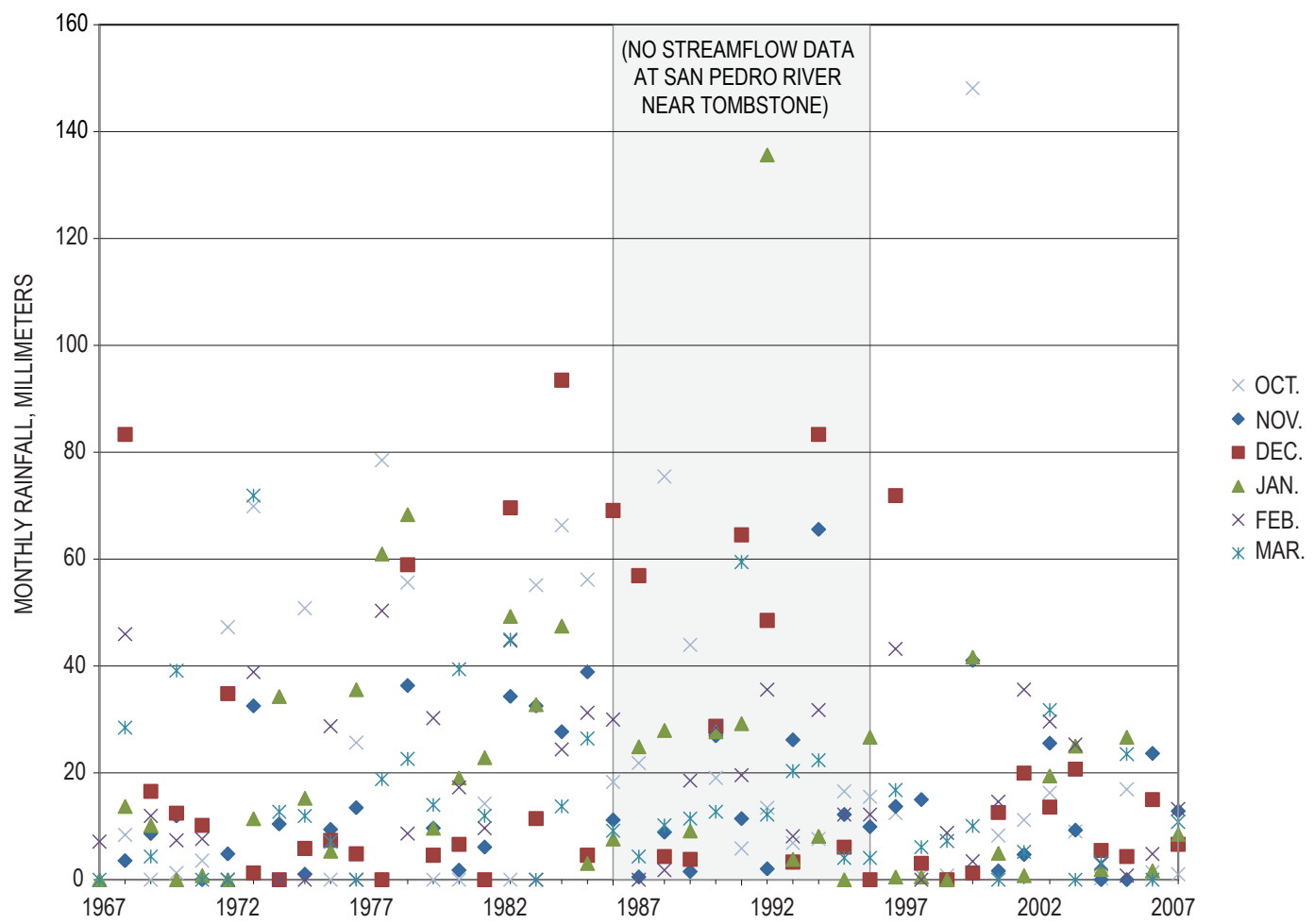

Figure 13. Graph showing monthly precipitation measured at Tombstone from October through March for each year from 1967 to 2009. Each month is plotted according to the calendar year, not water year. 
some correlation between precipitation and base flow would be expected. In addition, prior to the onset of flow in late fall/ early winter, direct infiltration of winter rainfall on the (dry) stream channel between the Charleston and Tombstone gages reduces seepage losses and serves to increase the volume of base flow. Occasional snowfall is generally insignificant at the low-elevation precipitation stations used in this study, and any snowpack at higher elevations does not contribute direct surface runoff to winter base flow in the San Pedro River.

Several dependent variables representative of winter base flow are possible, including (1) mean monthly flow after hydrograph separation using the delta filter outlined above, (2) monthly 3-day low flow, (3) the 25th percentile mean daily flow, (4) total flow volume from the base-flow-separated hydrograph, (5) the start date of winter base flow, and (6) the midwinter steady-state mean daily flow. The total flow volume from table 4 incorporates the effects of the start date of base flow, the midwinter steady-state mean daily flow, and the effect of any rainfall or stormflow that was not removed from the streamflow record by hydrograph separation. The start date of winter base flow is only identifiable in years when the river is dry or when there is a distinct minimum flow in the fall. In years when the river is dry in the fall, this value varies based on the particular stream channel configuration. As the wetting front advances downstream, it starts and stops based on the local bed composition and thickness. Because of the sand composition of the stream channel in the vicinity of the Tombstone gage, local channel shape changes from year to year. Streamflow may pool behind a small obstruction or dip in the channel and then advance rapidly once that section is saturated and (or) overtopped. The midwinter steady-state flow is reached when the stream channel is largely saturated, losses between the Charleston and Tombstone gages are minimal and steady, streamflow at the Tombstone gage is no longer increasing, and before ET causes a decrease in streamflow. In years with little winter precipitation, the midwinter steady-state flow can be identified manually as a plateau in the stream hydrograph or as a wide flat region in the center of the flow-duration curve (fig. 5). As with the start date, it cannot be identified every year.

Data transformations, such as the log transform, are often used with streamflow data to improve statistical analyses (Helsel and Hirsch, 2002). Tests of different transformations on discharge at the Tombstone gage show that a cube-root transform on the mean daily flow variables was useful to make the relation between them and base flow more linear. A cube-root transform was more satisfactory than a log, natural $\log$, or square-root transform. In addition, it has the advantage over log transforms that zero values in the data, as occasionally occur in the streamflow data, are preserved. Therefore, mean daily base flow, monthly 3-day low flow, and midwinter steady state flow were cube-root transformed before plotting and further analysis.

A scatter-plot matrix provides an efficient way to analyze the effect of several independent variables on several dependent variables. Many possible combinations were considered; only the most relevant are presented here. Plots of mean daily base flow, calculated for each month from the base flow-separated hydrographs, show a greater dependence on mean daily flow in September and October than on mean daily flow over the entire summer (fig. 14, left two columns), even though the greatest amount of rainfall is in July and August (fig. 12). Monthly 3-day low flow follows a similar pattern. The relation between summer streamflow (either July to October or September to October) and either January or February winter flow is nearly identical, indicating that the choice of time period of winter flow for regression analysis is relatively unimportant. A relation between winter flow and winter rainfall is also apparent (fig. 14, right two columns). This indicates that the base-flow separation process removes only the short-duration effect of rainfall and some longer-term effects remain. January rainfall has a higher correlation with winter base flow than December rainfall, and both of these months have higher correlations than October, November, or February (not shown). This is most likely because these two months have the highest amount of rainfall (fig. 13) and also because rainfall that occurs later during the winter cannot affect streamflow during the early winter.

Similar to winter base-flow rate, winter base-flow volume and 25th-percentile flow show a higher correlation with late summer streamflow than total summer streamflow (fig. 15). The other two metrics - start date of winter base flow and midwinter maximum - show little correlation with either summer streamflow or winter rainfall. Large scatter and generally low correlation coefficients for all of the scatter plots shown in figures 14 and 15 suggest that multiple independent variables influence base flow. For instance, high base flow could be caused either by a large amount of streamflow (and therefore storage in the near-stream aquifer) during the summer or by a large amount of rainfall during the winter.

Having determined that winter base flow is correlated to summer streamflow, it is helpful to find the period of time in the summer to which base flow is most closely related. To avoid using arbitrary month-long divisions or arbitrary start and end dates over which to average summer streamflow, a response surface of the $\mathrm{R}^{2}$ statistic for different summer time frames is used (fig. 16) to identify the period in summer with the highest correlation to winter base flow. A moving window with a variable span from 5 to 45 days and with a midpoint varying from July 1 to October 20 was identified, and the average mean daily flow during that window was calculated for each year. Later midpoints were not considered to be representative of summer rainfall. Next, the $\mathrm{R}^{2}$ statistic (also known as the coefficient of determination) between summer streamflow and winter base flow for a LOWESS regression is calculated as

$$
R^{2}=1-\frac{\sum_{i}\left(y_{i}-f_{i}\right)^{2}}{\sum_{i}\left(y_{i}-\bar{y}\right)^{2}}
$$

where $y_{i}$ is the observed winter base flow (either total volume or 3-day low flow), $f_{i}$ is the predicted winter base flow for a 
given summer streamflow, and $\bar{y}$ is the mean observed winter base flow. Each $\mathrm{x}, \mathrm{y}$ pair in the $\mathrm{R}^{2}$ calculation is the mean daily summer flow within a given window and the base flow for the following winter, respectively. Thirty-one years were considered. Finally, a contour plot is constructed from the $\mathrm{R}^{2}$ values for each window span and midpoint, using warmer colors for stronger correlations.

The response surface shows that streamflow early in the summer has little effect on winter base flow (fig. 16). Not surprisingly, streamflow in late summer has the greatest influence on winter base flow. The highest $\mathrm{R}^{2}, 0.7$, occurs when a window from 25 to 55 days and a midpoint between October 5 and October 20 is used. To simplify further regression analysis, October mean daily flow is used as an independent variable. In essence, this is the same as using a window with a span of 30 days and a midpoint of October 15 .

A multiple LOWESS-regression model was constructed using S-Plus statistical software (Insightful, 2001) that uses the cube-root of October mean daily flow and the combined December and January precipitation as explanatory/independent variables and winter base-flow volume as the dependent variable. Other models were considered and rejected because of low $\mathrm{R}^{2}$ values or over-parameterization. Given the limited time span and sample size of the analysis, overparameterization would allow too many degrees of freedom in the regression model and misleading uncertainty estimates. The span parameter of the LOWESS regression model controls the window size considered in the local regression

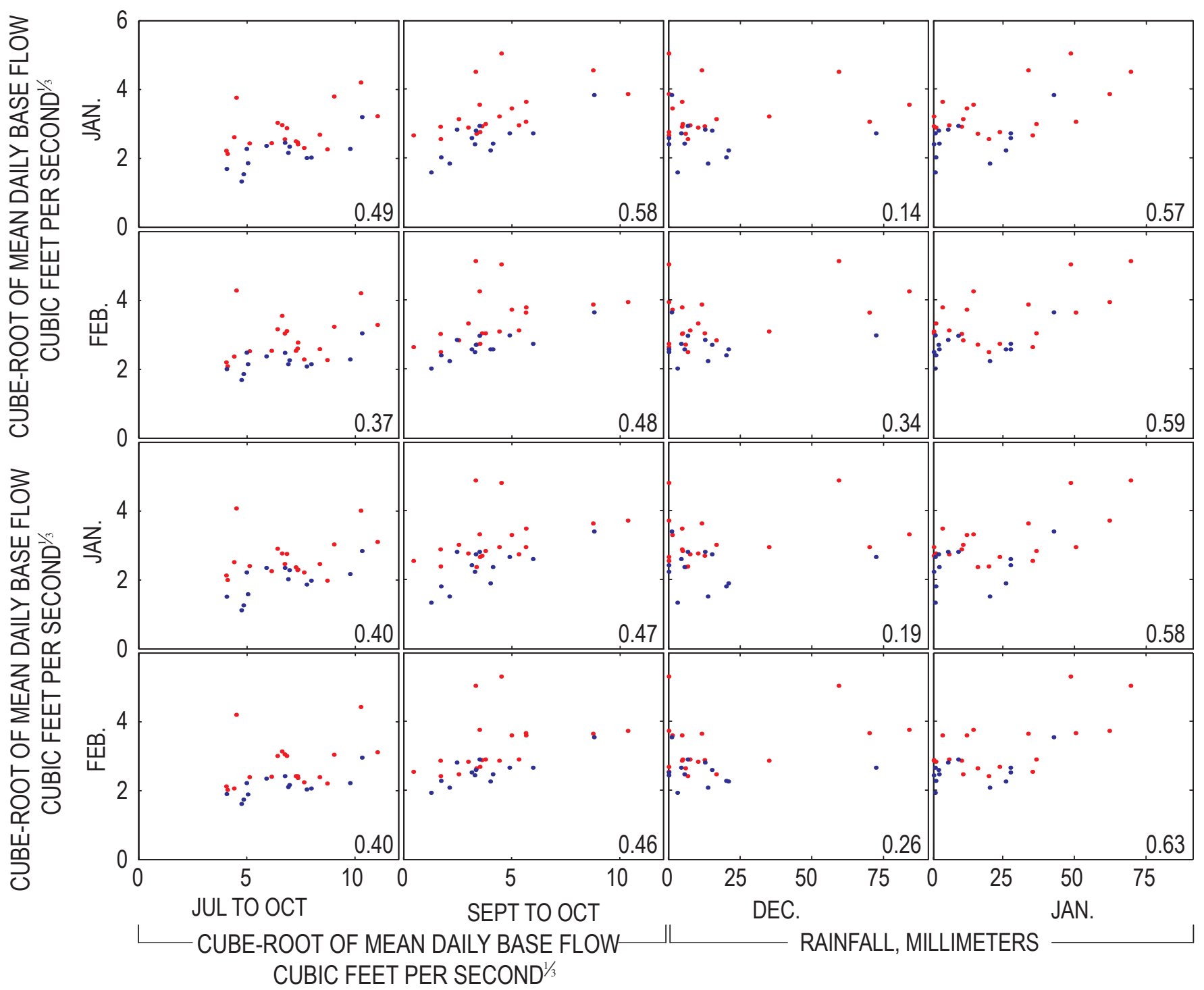

Figure 14. Scatter plot matrices of winter base flow (mean monthly flow after hydrograph separation) and monthly 3-day low flow vs. summer streamflow and winter precipitation. Red points represent the early period of record at the gaging station near Tombstone, from 1968 to 1986, and blue points represent the later period, from 1997 to 2009. Values are the Pearson correlation coefficient. 
and, therefore, the degree of smoothing. A value of 0.75 was found to work well. A locally linear model was used because the equivalent number of parameters, 5.4, was nearly half that of a locally quadratic model. Because of the non-parametric nature of LOWESS, no intercepts are calculated to directly examine the effect of multiple explanatory variables. Instead, a response surface can be used to graphically show the interaction of variables.

The LOWESS response surface is constructed by evaluating the model over a range of input parameters (independent variables) and plotting the predicted dependent variable at that location. This surface shows a strong dependence on both winter rainfall and the cube-root of October mean daily flow
(MDF) (fig. 17). Care must be taken in evaluating the response surface; the model results outside of the domain of the input data should be treated as suspect. In particular, the region of the response surface that curves upward at low values of winter rainfall and high values of October MDF is an artifact of the model and not representative of how the system would respond to these conditions. The model is most realistic for values that fall in the low rainfall/low October MDF quadrant.

As expected, the highest base-flow volume is predicted for the combination of high October MDF and high winter rainfall, and the lowest base-flow volume is predicted for low values of each. A comparison of the data used to construct the LOWESS model (red dots) with the model itself (fig. 17)

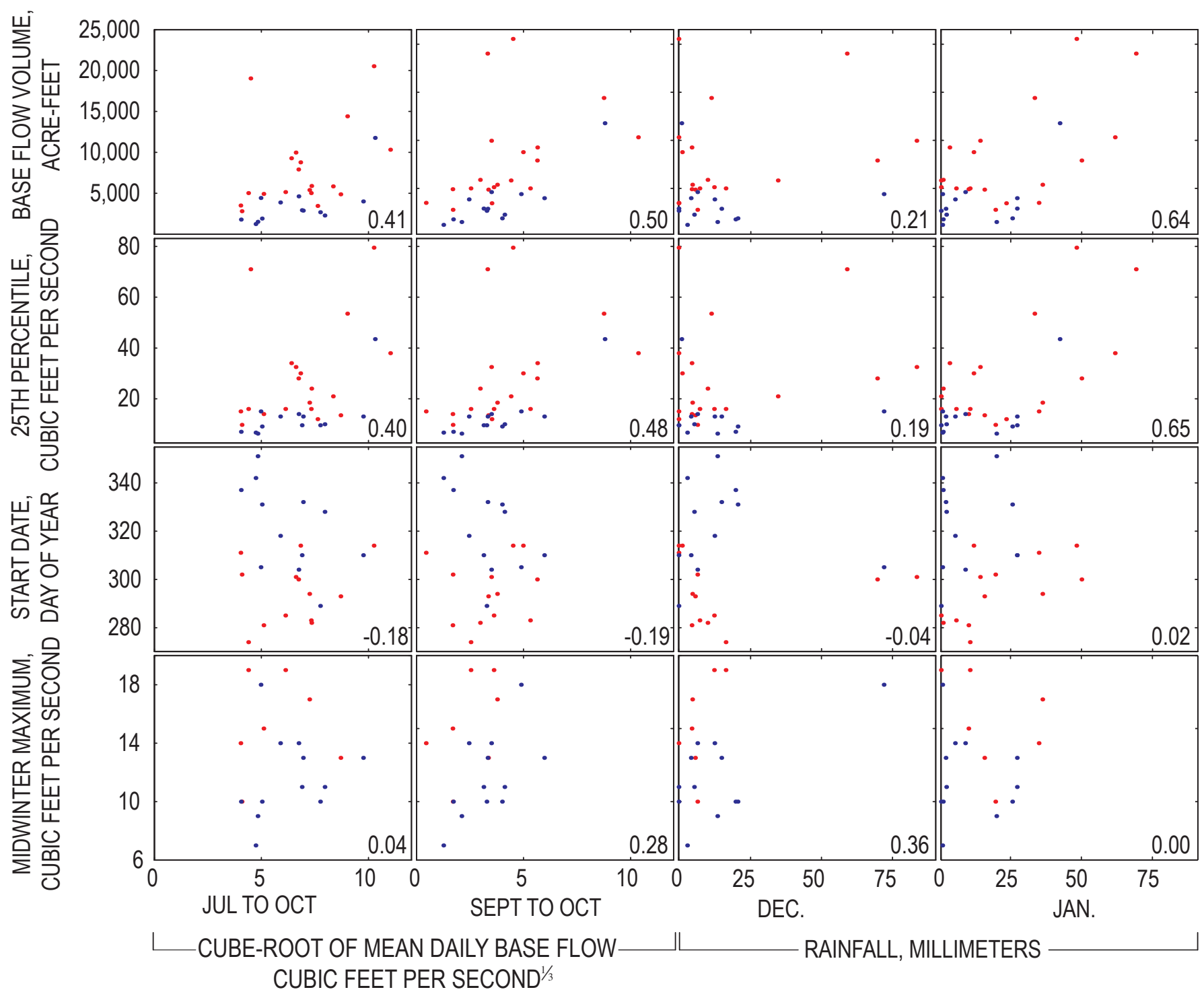

Figure 15. Scatter plot matrices of four different base-flow metrics vs. summer streamflow and winter precipitation. Red points represent the early period of record at the gaging station near Tombstone, from 1968 to 1986, and blue points represent the later period, from 1997 to 2009. Values are the Pearson correlation coefficient. 
shows that nearly all years lie in the low October MDF/low winter rainfall quadrant. Here the model is more sensitive to October MDF than rainfall, suggesting that there may be a minimum threshold for winter rainfall, and rainfall amounts below this threshold have little effect. Outside of this quadrant, the model is defined by fewer points. The largest amount of base flow occurs in years that have high rainfall amounts and moderate October MDF; during years that have only moderate winter rainfall but high October MDF, base flow is somewhat less. $\mathrm{R}^{2}$ for the LOWESS regression is 0.90 , indicating that 90 percent of the variation in winter base flow can be explained by the variation in October MDF and combined December and January precipitation. This value may be somewhat misleading, however, because it is determined largely by outlying data in two clusters: two closely spaced points with high rainfall and moderate October MDF and three closely spaced points with high October MDF and moderate rainfall.

Model residuals - the measured value minus the value predicted by October MDF and winter rainfall - provide further diagnostics of the LOWESS regression model. The residual interquartile range, between the 25 th and 75 th percentiles, is -783 acre-ft to 872 acre-ft. In other words, the model would be able to predict the measured base flow within about 800 acre-ft for 50 percent of the time. Considering that many of the base-flow values are 4,000 acre-ft or less, these residuals are relatively large. A plot of the residuals versus the base-flow value predicted by LOWESS regression shows near-constant variance for smaller volumes of predicted base flow; a lack of samples at larger volumes of base flow precludes estimation of residual variance for the entire range of model predictions (fig. 18B). Significant year-to-year variation remains in the predicted values, but the model is able to estimate the mean value. Further evidence for normally distributed residuals with constant variance are shown by plots of measured vs. predicted base flow, and the residuals vs. standard normal quantiles (fig. 18A, C).

The residuals from the LOWESS regression represent values from which the effect of year-to-year climate variation has largely been removed. Statistical tests on the residuals can be used to determine whether the streamflow record at the gaging station near Tombstone during the later period is significantly different than the earlier period. If so, such differences would be due to factors other than rainfall. Common trend tests, such as the non-parametric Kendall tau test, are not applicable in this instance because of the missing data in the record between 1986 and 1996. Instead, a test comparing two samples is used. The Wilcoxon rank-sum test (equivalent to the Mann-Whitney test) compares the median of two samples for significant differences, making no assumptions about the underlying distribution of the data (Helsel and Hirsch, 2002). The null hypothesis, that the two groups are from the same population (in this case, that winter base flow, when adjusted for annual rainfall, is the same for the earlier period as for the later period), is tested by comparing the test statistic to a table of values. Like most statistical tests, the rank-sum test is only capable of rejecting a null hypothesis; this does not necessarily

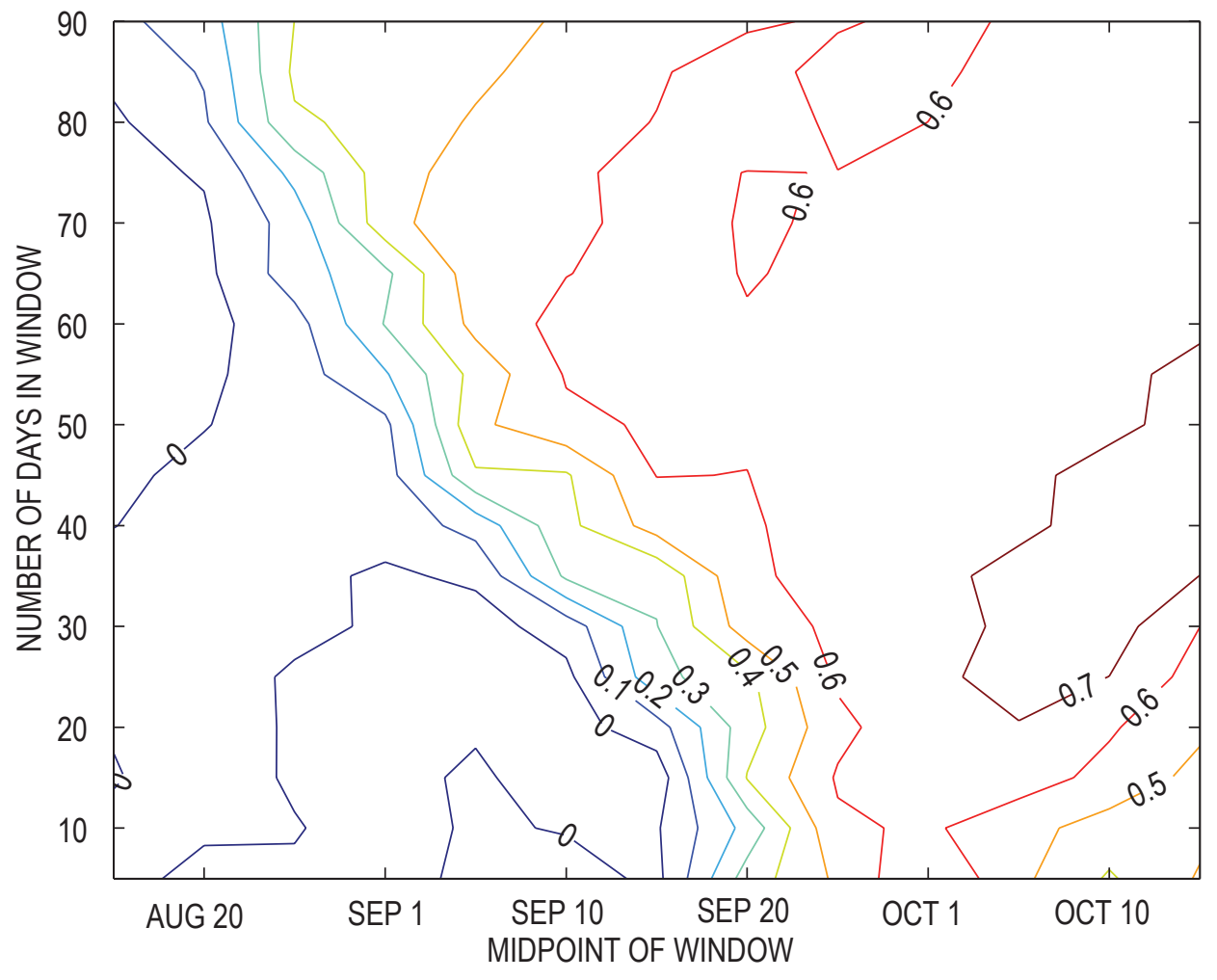

Figure 16. Graph of response surface showing the coefficient of determination $\left(R^{2}\right)$ for the summer streamflow vs. winter baseflow linear regression. Summer streamflow is calculated as the average mean daily flow over a time span of $n$ days, shown on the $y$-axis, centered on the date on the $\mathrm{x}$-axis. 
indicate acceptance of an alternate hypothesis. For this study, the level of significance - that is, the probability of rejecting the null hypothesis when it is in fact true-is set at 5 percent.

Annual adjusted base flow, corrected for year-to-year climate variability using the LOWESS regression, is calculated as mean base flow for all years plus the regression residual. Adjusted base flow is lower than measured base flow in wetter years and higher than measured base flow in drier years (fig. 19). Adjusted base flow during the later period of record appears to be lower than the earlier period. The rank-sum test applied to the adjusted base flow indicates that the null hypothesis (that there is no difference between the early period and late period) should be rejected. The p-value for this test is 0.0033 , indicating that the probability of a Type I error-when the null hypothesis is rejected but is in fact true-is less than 1 percent, which supports the hypothesis that some factor other than climate is responsible for the decline in base flow at the gaging station near Tombstone.

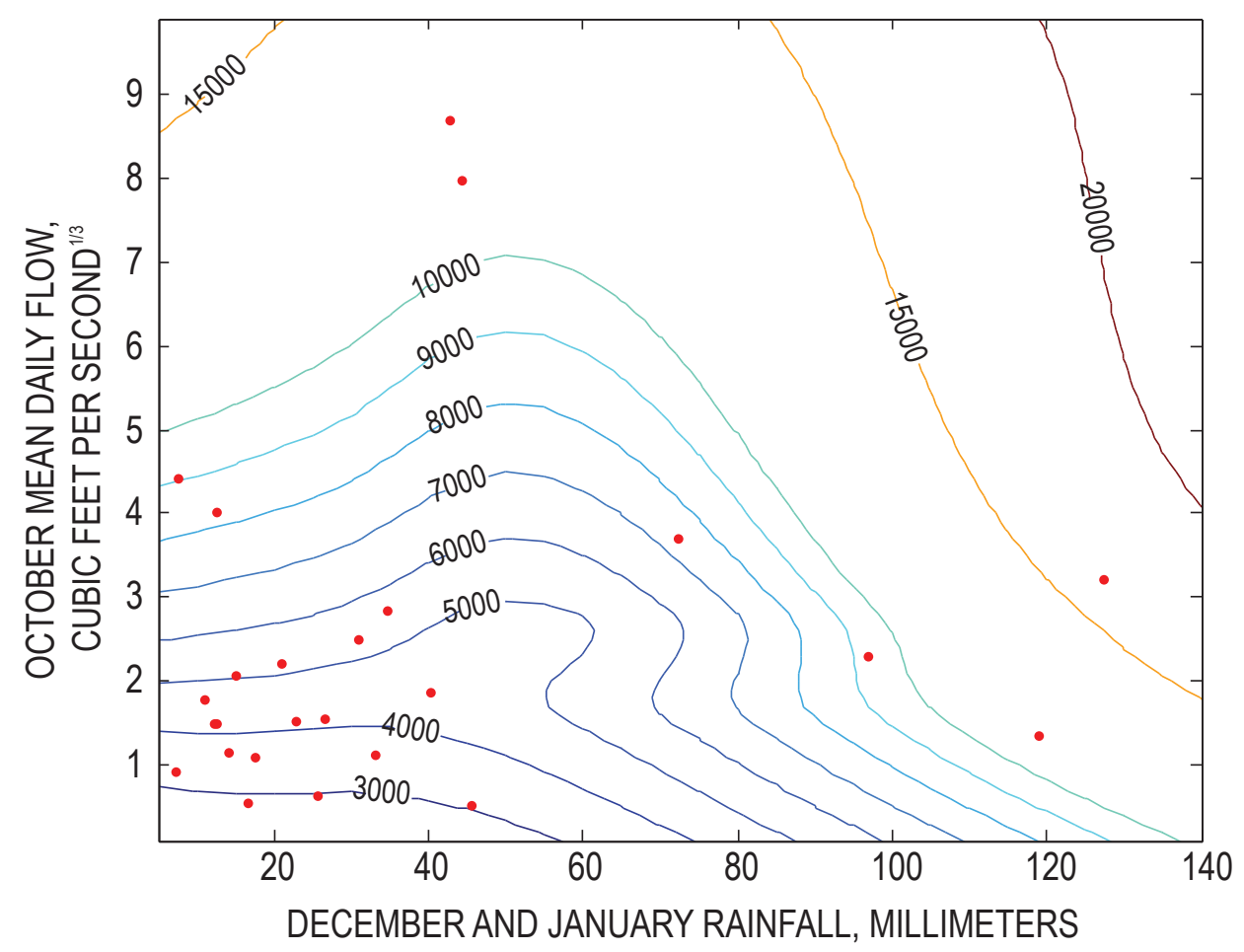

Figure 17. Graph showing the response surface of the LOWESS multiple-regression model for varying values of the independent variables of December to January rainfall and cuberoot of 0 ctober mean daily flow. Red points are the measured base flow used to construct the model.
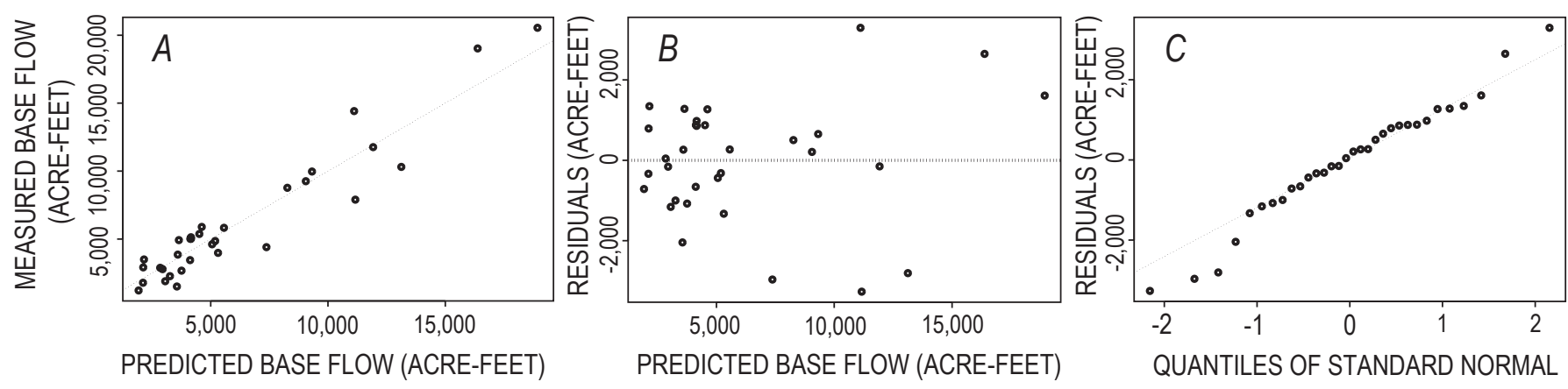

Figure 18. Graphs showing LOWESS regression diagnostic characteristics: $A$, scatter plot of measured vs. predicted base flow, $B$, regression residuals vs. predicted base flow, $C$, regression residuals vs. standard normal quantiles. 


\section{Change in Base Flow from Reduced Inflow from the Regional Aquifer}

Exchange of water between the regional aquifer and alluvial aquifer is driven by hydraulic gradients, measured by comparing piezometer water levels at two different horizontal and (or) vertical locations. Positive vertical gradients indicate upward movement of water; negative gradients are the reverse. A zero hydraulic gradient indicates hydrostatic equilibrium and no movement of groundwater. A decrease in groundwater movement towards the river, caused by groundwater pumping between the mountains and the river, would be reflected by a decrease in the measured hydraulic gradient. Gradients may also be influenced by withdrawal of water from the alluvial aquifer by ET. As this water is removed, the water-table elevation in the near-stream aquifer lowers. Because the root zone of riparian vegetation does not extend to the deeper aquifer, water-table elevation there is unaffected by ET. Therefore the gradient becomes more positive, because the difference between the water-level elevations increases.

Vertical gradient measurements have been made at a number of locations near the San Pedro River beginning around year 2000 (table 5). Piezometer pairs are typically deep and more representative of the regional aquifer (well names beginning with BOQ, CLR, LSP, HER) or shallow and representative of the alluvial aquifer (well names beginning with CON, FBK, MOS, COT). Gradients are generally positive at all locations, except at constantly negative HER wells and at FBK and MOS wells that alternate between positive and negative gradients as a result of seasonal ET withdrawals (fig. 20). Data from seven of the eight piezometer pairs show essentially no trends over time, either in water level or gradient. An exception to this lack of trend is seen at Lewis Springs where water levels have risen in both the deep and shallow piezometers. Water level has risen faster in the shallow well, resulting in a decrease in the vertical gradient. This decrease in gradient is not attributable to a decrease in water level, such as would be caused by pumping. Most piezometer locations show fluctuations in water level during the summer monsoon, but these do not persist as longer-term trends.

Despite variation in climate, water levels and gradients in wells located near the San Pedro River show little interannual variability. The period from 2000 to 2010 has exhibited both wet periods (October 2000, summer 2006 and 2008) and extreme dry periods (summer 2002 to 2004, summer 2010, winter 2002 and 2006). The lack of decline in water levels and gradients during this period is evidence that the cone of depression caused by groundwater pumping in the Sierra Vista area has not significantly affected vertical gradients in and near the alluvial aquifer during the period and in the locations for which water level data exist. If groundwater pumping was affecting conditions in the alluvial aquifer, a continual and increasing decline in gradients would be expected. Apart from small fluctuations during the summer monsoon, neither wet

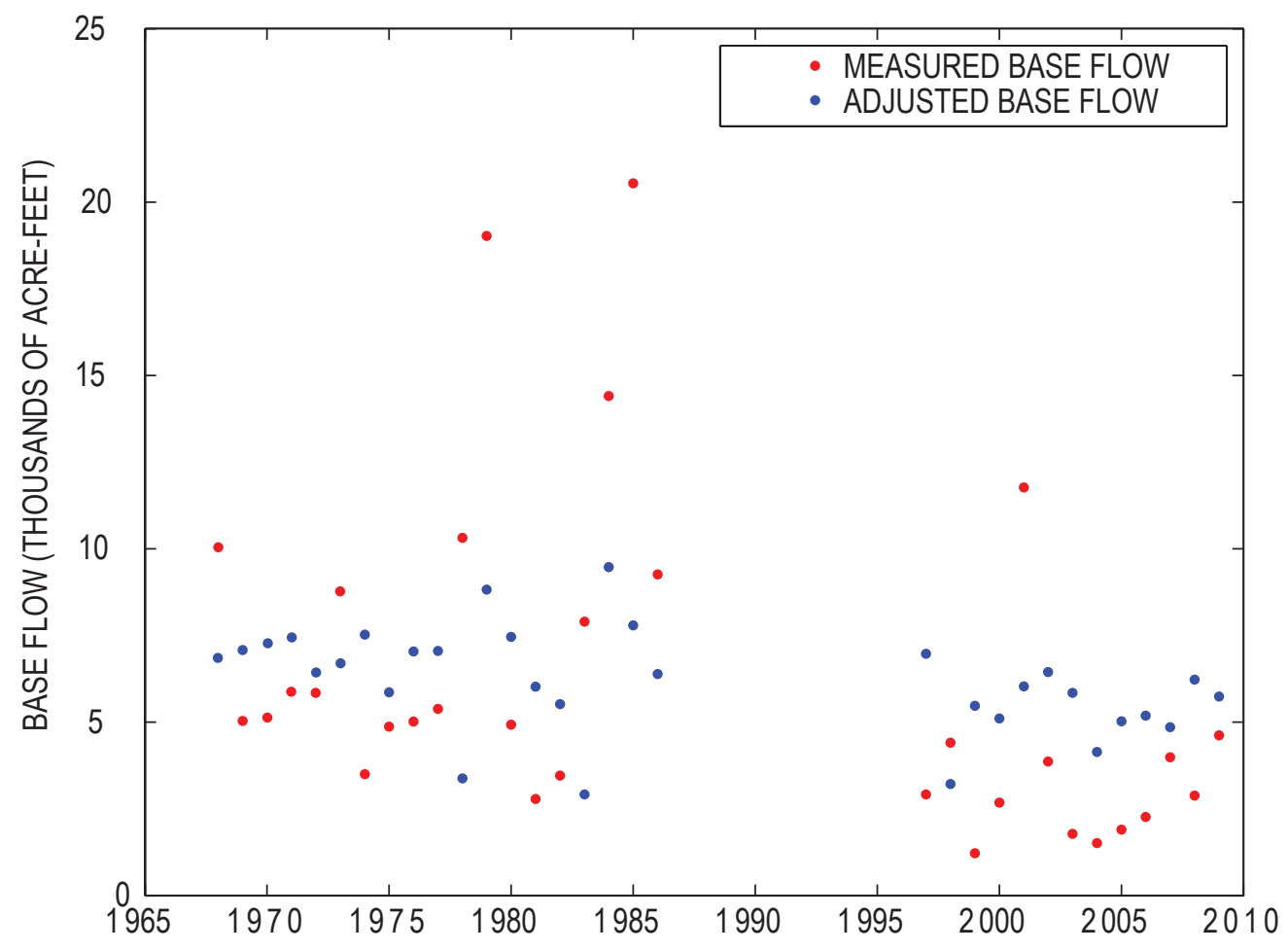

Figure 19. Graph showing measured and adjusted base-flow volume. Adjusted values are based on the LOWESS regression shown in figure 17. 
Table 5. Description of wells used in vertical gradient analysis.

[UTM N, Universal Transverse Mercator Zone 12 N northing; UTM E, Universal Transverse Mercator Zone 12 N easting]

\begin{tabular}{lcccccc}
\hline Well name & USGS site ID & UTM N & UTM E & Cadastral ID & $\begin{array}{c}\text { Well depth } \\
\text { (m) }\end{array}$ & $\begin{array}{c}\text { 份tance } \\
\text { upstream } \\
\text { from Tomb- } \\
\text { stone gage } \\
\text { (km) }\end{array}$ \\
\hline HER-SUS & 312642110063701 & 3479288 & 584481 & D-23-22 09ACD1 & 25.5 & 35.0 \\
HER-SUD & 312642110063702 & 3479284 & 584481 & D-23-22 09ACD2 & 37.6 & 35.0 \\
COT-BLM & 313105110074501 & 3487517 & 582637 & D-22-22 17ACC3 & 8.2 & 26.5 \\
COT-UCD & 313105110074502 & 3487519 & 582641 & D-22-22 17ACC4 & 16.2 & 26.5 \\
LSP-1 & 313312110082302 & 3491201 & 581654 & D-22-22 06AAA1 & 10.5 & 22.5 \\
LSP-5 & 313312110082303 & 3491200 & 581648 & D-22-22 06AAA5 & 54.9 & 22.5 \\
CLR-SUS & 313508110085701 & 3494840 & 580667 & D-21-22 19CDB1 & 19.3 & 19.0 \\
CLR-SUD & 313508110085702 & 3494838 & 580671 & D-21-22 19CDB2 & 52.9 & 19.0 \\
MOS-LNS & 313643110100101 & 3497725 & 578961 & D-21-21 13BAB1 & 3.7 & 15.5 \\
MOS-LND & 313643110100102 & 3497723 & 578963 & D-21-21 13BAB2 & 6.1 & 15.5 \\
BOQ-SUS & 314144110104701 & 3506985 & 577665 & D-20-21 14BCC1 & 14.0 & 6.5 \\
BOQ-SUD & 314144110104702 & 3506985 & 577665 & D-20-21 14BCC2 & 51.4 & 6.5 \\
FBK-LI & 314318110113101 & 3509846 & 576427 & D-20-21 3CBA & 4.9 & 2.8 \\
FBK-LO & 314317110113401 & 3509871 & 576504 & D-20-21 3CAB & 6.2 & 2.8 \\
CON-SUS & 314558110121601 & 3514779 & 575268 & D-19-21 21DBB2 & 8.2 & -2.0 \\
CON-SUD & 314558110121602 & 3514780 & 575265 & D-19-21 21DBB1 & 16.2 & -2.0 \\
\hline
\end{tabular}

nor dry periods appear to have much lasting effect on vertical gradients. In contrast, water levels at a majority of wells in the greater Sierra Vista area to the west of the river show consistent declines between 2001 and 2006, with a decrease of as much as $9 \mathrm{~m}$ at some wells (Schmerge and others, 2009). This leads to the conclusion that, to date, conditions in the deeper alluvial aquifer are largely independent of both annual variation in rainfall and groundwater withdrawals. Of course, basic hydrologic understanding indicates that, with continued pumping, the cone of depression will eventually affect the alluvial aquifer and capture streamflow (Leake and others, 2008).

Change over time in the isotopic composition of base flow could also be an indicator of reduced inflow from the regional aquifer. If the isotopically depleted water in the Sierra Vista area contributes to base flow, as the mixing analysis suggests, a decrease in base-flow contribution from this source due to groundwater pumping would cause base flow to become more isotopically enriched. A Mann-Kendall trend test (Helsel and Hirsch, 2002) is used to evaluate trends in isotopic composition. A single $\delta^{18} \mathrm{O}$ value is selected for each year; in this case the most depleted value from the winter base-flow season is used to minimize any isotopic enrichment effect. Although this $\delta^{18} \mathrm{O}$ value is correlated somewhat with annual precipitationdrier years have a more depleted isotopic composition, representing an increased proportion of regional groundwater - this effect was not sufficiently significant to be accounted for using regression analysis $\left(\mathrm{R}^{2}=0.14\right.$ using the same independent variables used in the LOWESS regression). The trend test indicates that the null hypothesis - that there is no trend - should not be rejected $(p=0.37)$. Therefore, similar to the hydraulic gradient data, isotope concentrations do not indicate a decline in the regional groundwater contribution to base flow.

\section{Spatial Pattern of the Change in Base Flow}

An additional method used to evaluate trend in base flow in the San Pedro River, and the difference between the early and late period of record at the Tombstone gage, is to compare winter base flow at different locations along the river. Three-day low flow in January and in February is used, because it was shown to be very similar to the base flowseparated mean daily flow and is a more consistent measure than using the hydrograph separation method at different stations. Discharge records are available at San Pedro River 

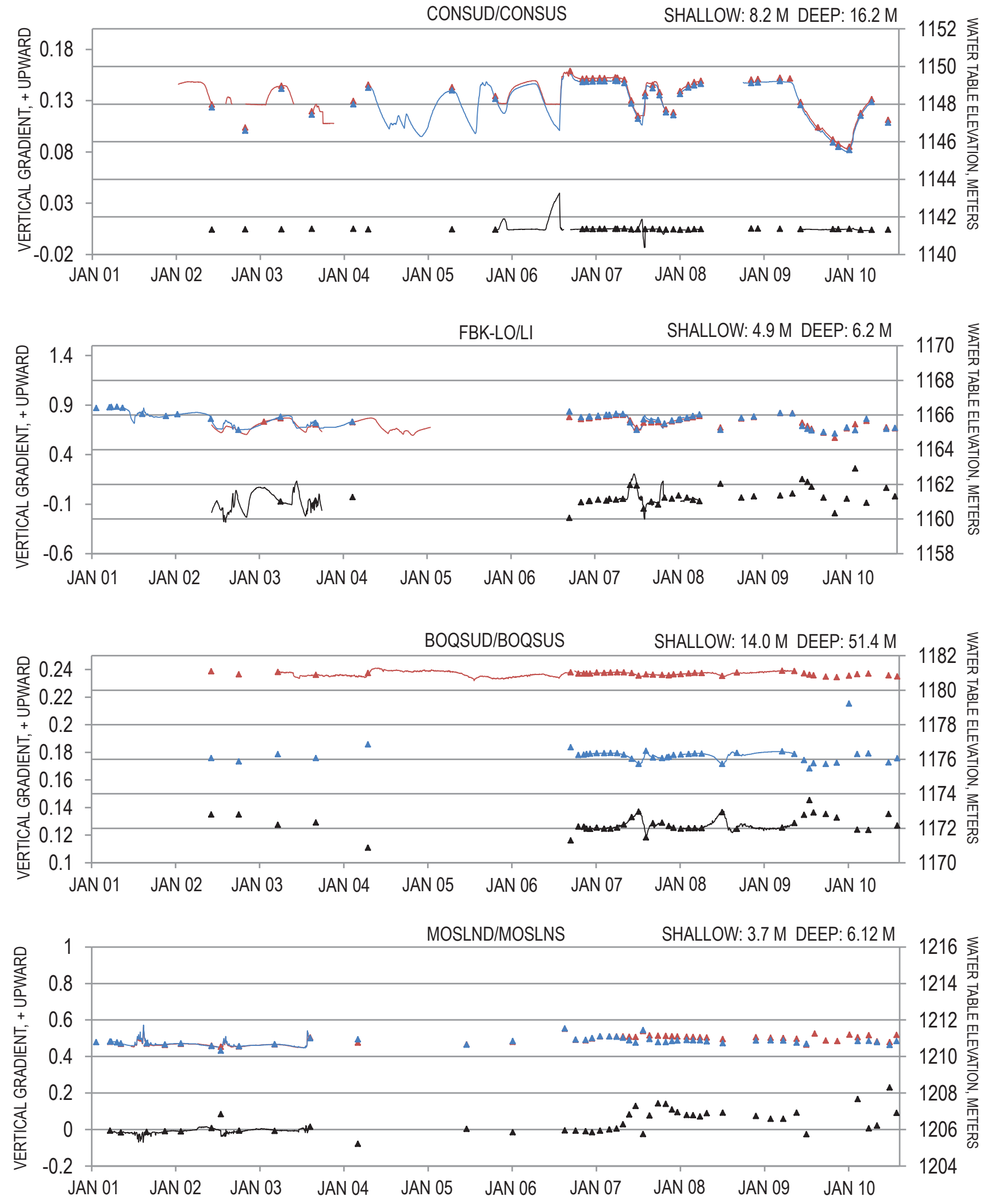

$\hookrightarrow$ VERTICAL GRADIENT —DEEP WELL, WATER LEVEL ELEVATION — $\leadsto$ SHALLOW WELL, WATER LEVEL ELEVATION

Figure 20. Graphs showing vertical gradient and water-level elevation at eight paired wells near the San Pedro River. Wells are in order from north at the top to south at the bottom. Locations of wells are shown in figure 1. Solid lines are pressure transducer measurements and triangles are tape-down measurements. 

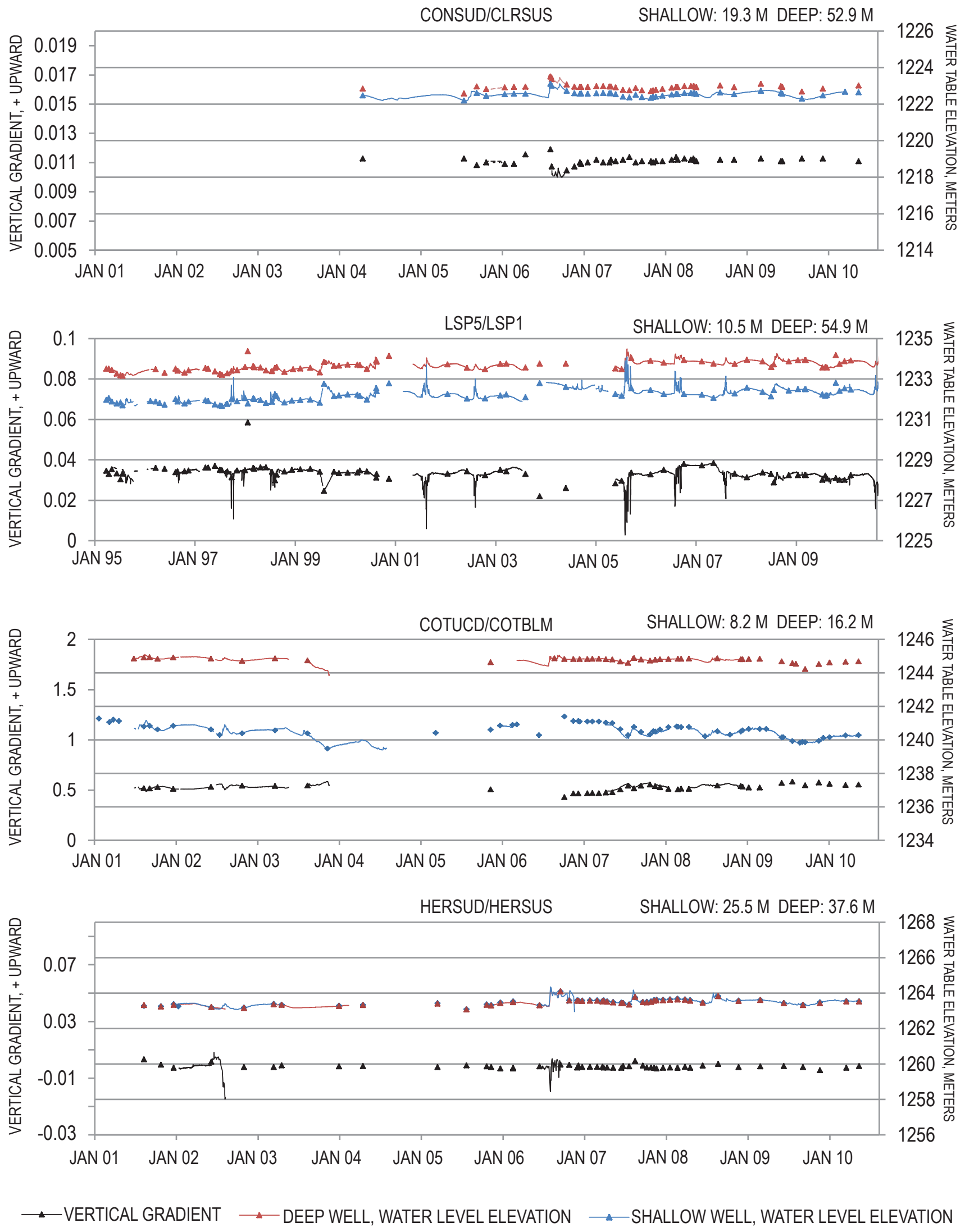

Figure 20.-Continued. 
at Palominas (station number 09470500, $41.5 \mathrm{~km}$ upstream of the Tombstone gage), San Pedro River at Charleston (station number $09471000,14 \mathrm{~km}$ upstream of the Tombstone gage), and San Pedro River near Tombstone (station number 09471550). The record at the Palominas gage ends in 1982; therefore, the early period common to all three gages is 1968 to 1981 , and the later period is 1997 to 2009 . This removes a relatively wet period from 1983 to 1986 during which streamflow data exist at the Tombstone gage.

The low-flow data show that the largest decrease in streamflow between the early and late periods is at the Tombstone gage (fig. 21). A smaller decrease is evident at the Charleston gage, and no decrease is evident at the Palominas gage. This suggests that changing conditions between the Tombstone and Charleston gages and between the Charleston and Palominas gages are more important to the decrease in base flow at the Tombstone gage than changing climate, as reflected by conditions at the Palominas gage. Changing conditions could include a decrease in base flow caused by decreased hydraulic gradient near the river or an increase in ET withdrawals. Even though ET is small in the winter months, its increase in the summer would further deplete storage in the near-stream alluvial aquifer and magnify losing conditions until that storage is replenished.

Another feature of interest in the box plots of winter low flow (fig. 21) is the change in variability between the gages. Winter low flow at the Palominas gage is the most consistent (lowest inter-percentile change between the early period and late period). Flow at the Tombstone gage, particularly during the early period, is more variable, and flow at the Charleston gage plots between Palominas and Tombstone flows. This increase in variability in downstream distance is caused in part by the variation in year-to-year near-stream aquifer storage. This is a result of the larger watershed area at downstream gages, as the streamflow record integrates the spatial variability of gaining and losing reaches upstream.

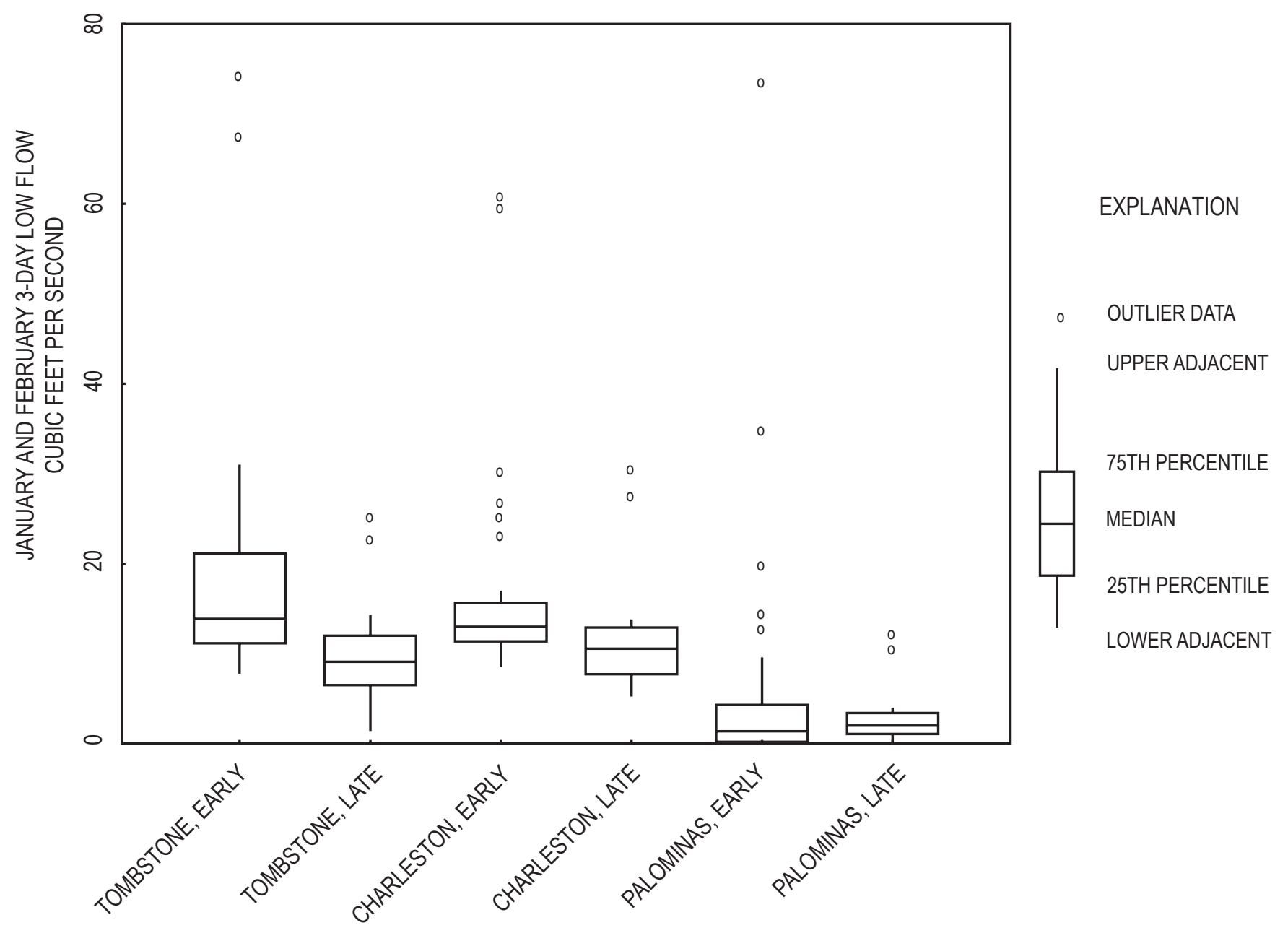

Figure 21. Box plots showing January and February 3-day low flow at San Pedro River at Palominas (station number 09470500), San Pedro River at Charleston (station number 09471000), and San Pedro River near Tombstone (station number 09471550). The early period of record is 1968 to 1981, and the late period of record is 1997 to 2009. 


\section{Discussion}

The actual cause of the decline in winter base flow between the early and late periods of record at the Tombstone gage is most likely a combination of factors. The largest decrease in streamflow is in the fall, and the pattern of springtime recession remains largely unchanged. This points to higher ET rates due to more vigorous or expansive vegetation and (or) a longer growing season due to the later arrival of the first frost of the fall. Repeat analysis of aerial imagery shows a marked increase in riparian vegetation cover between 1978 and 2003 (Stromberg and others, 2010). Although this increase is minimal immediately upstream of the Tombstone gage, every reach above the BOQSUD/BOQSUS wells exhibits an increase in Populus-Salix (cottonwood and willow) cover, largely at the expense of bare ground rather than a conversion of some other vegetation type. In addition, over 40 percent of the Populus fremontii population has been established since 1970. This dramatic increase in vegetation is strong evidence that increased ET has had an effect on declining winter base flow at the Tombstone gage.

Although vegetation, and therefore ET, has increased, the maximum steady flow rate reached in the winter, when ET is minimal, has also declined. While this could be evidence for a decline in regional groundwater contribution to streamflow, the midwinter steady flow rate is also partially dependent on summer runoff. Losing conditions between the Charleston gage and the Tombstone gage can explain the decline in the midwinter steady flow rate at the Tombstone gage independently of any change in the regional groundwater component of winter base flow. This is because the amount of water in storage in the near-stream alluvial aquifer depends primarily on streamflow from the previous summer and withdrawal by ET during the fall and, therefore, varies widely from year to year. During the driest years, most of the base flow measured at the Charleston gage infiltrates downstream and has little influence on the rate of winter base flow at the Tombstone gage. The alluvial aquifer never becomes fully saturated, losing conditions do not diminish substantially, and the river does not attain a steady flow rate at the Tombstone gage. In this way, the maximum flow rate reached in the winter is reflective of summer runoff and regional groundwater contributions to winter base flow.

The effect of a decline in groundwater contribution to winter base flow is more difficult to assess than changes in ET or climate. In wet years, this decline would manifest as a lower midwinter steady flow rate, which typically exists for a period of days to weeks when the alluvial aquifer is saturated and when riparian ET and, therefore, seepage loss is minimal. In a dry year, however, much of the winter base flow at the upstream Charleston gage infiltrates into the evapotranspiration-depleted alluvial aquifer between the gages, and a midwinter steady flow rate is not reached before springtime ET begins. Most years during the period 1997 to 2009 were drier than average, with several extremely dry years. Therefore, the midwinter steady flow rate at the Tombstone gage during this period was controlled primarily by the magnitude of the alluvial-aquifer storage deficit, caused by ET following the previous summer and fall, rather than by the rate of inflow from the regional aquifer.

Because of the difficulty in evaluating the midwinter steady flow rate, water levels and hydraulic gradients in the alluvial and regional aquifers are used. Data from paired piezometers at eight locations upstream of the Tombstone gage, in both the alluvial and regional aquifers, indicates no trend in water levels or vertical gradient since 2001. The percent of regional and alluvial groundwater determined by isotopic analysis has also remained relatively constant from 2000 to 2009. Together, these data show that any decline in winter base flow during the past 10 years at the Tombstone gage caused by changes in the regional aquifer is minimal.

An important consideration regarding base flow at the Tombstone gage is that rainfall varies year-to-year, as well as on decadal scales. The later part of the record at the Tombstone gaging station, from 1997 to 2009, represents a dry period relative to the earlier period, from 1968 to 1986. When the long-term precipitation record (1931 to 2009) in the Subwatershed is considered, however, the later, drier period of record is much closer to the long-term average than the earlier period of record (fig. 12). In other words, from 1968 to 1986 it was unusually wet in the Subwatershed, while from 1997 to 2009 it has been more typically dry. Nevertheless, when climate effects are removed from the base-flow record, there remains a significant decrease in winter base-flow discharge in the later period.

Changes in near-stream groundwater pumping during the study period are not considered in this report. Significant amounts of irrigated agricultural land upstream from the Charleston gage have been retired since the beginning of the streamflow record at the Tombstone gage (Department of the Interior, 2005). About $6 \mathrm{~km}$ upstream of the Tombstone gage, the Boquillas Ranch had irrigated pasture land until it was incorporated into the BLM San Pedro Riparian National Conservation Area in 1988. An indeterminate amount of agricultural pumping occurred on the west side of the river, south of Arizona Route 90, between the early 1970s and the early 1980s. In 2005, the last significant irrigated acreage in the Subwatershed, near Palominas, was retired. Lack of definitive information about the amount and distribution of pumping associated with this irrigation precludes detailed analysis. If irrigation was responsible for significant withdrawals from the alluvial aquifer during the early period of record at the Tombstone gage, this would tend to reduce the difference in base flow between the early period and late period (that is, the early period would have experienced higher base flow without the withdrawals for irrigation).

The results of this report have implications for the water budget. Base-flow discharge from the Subwatershed at the Tombstone gaging station represents surface discharge from the Subwatershed of groundwater that has been discharged to the stream. As such, an increase in the long-term, mean 
outflow at the Tombstone gaging station would indicate an improvement in the regional aquifer condition, and this would be reflected in the water budget - more water would be available from the regional aquifer to enter the river and subsequently exit the Subwatershed as base flow. This condition would imply that other lines in the water budget have also changed, such as a reduction in withdrawals (pumping, ET) and (or) an increase in recharge (climate change, effluent, secondary water source). Alternatively, if the "Stream base flow" line in table 1 is adjusted, because of an improvement in the estimation of base flow (as the case in this report), then nothing else in the water budget is affected except for the bottom line, which will change by a similar amount; we have simply improved the accuracy of the existing water budget.

As noted in the "Previous Studies" section, above, earlier studies that estimated base flow for the San Pedro River at the Tombstone gaging station intrinsically included both alluvial aquifer discharge and regional aquifer discharge to arrive at those estimates. Most estimates of natural recharge in the Subwatershed have been back-calculated from estimated base flow, because, for a system in equilibrium, the groundwater discharging from the system (base flow) must be equal to the water entering into the system (recharge). If a water budget uses an estimate of natural recharge based on a predevelopment base-flow value that includes all groundwater discharged to the stream (both alluvial and regional aquifer discharge), then, to be consistent, any refinements to the base-flowdischarge value in the Subwatershed water budget should similarly include all groundwater discharged to the stream. Alternatively, if the natural recharge value is determined directly (and excludes alluvial aquifer recharge) or is based solely on an estimate of predevelopment regional groundwater discharge, then any refinements to the water-budget base-flow discharge value should similarly include only regional groundwater discharge. Complicating this analysis is the possibility that the relation between regional and alluvial groundwater storage has changed between the predevelopment period and the present. If regional groundwater gradients have decreased over time, resulting in less regional groundwater discharge to the alluvial aquifer and to the stream channel, infiltration of streamflow into the alluvial aquifer could increase. In effect, this would result in alluvial aquifer storage becoming increasingly derived from streamflow rather than regional groundwater, while total discharge from the alluvial aquifer remains relatively constant. In any case, the data needed to evaluate this scenario, primarily long-term records of hydraulic gradients within the regional and alluvial aquifer, are not available.

\section{Summary and Conclusion}

This report quantifies the amount and sources of winter base flow in the San Pedro River near Tombstone. Annual base flow is composed entirely of winter base flow, because summer ET rates are higher than summer groundwater discharge, resulting in no base-flow contribution to streamflow at the Tombstone gage during the summer months. Consequently, summer streamflow at the gage is due entirely to intermittent monsoon precipitation, because no flow occurs at the gage during much of the summer. Winter streamflow comprises short-duration stormflow owing to direct precipitation, previously infiltrated streamflow stored temporarily in the near-stream aquifer, and water that is recharged away from the river, along the mountain fronts and the ephemeral channels of the basin. Analytical methods were used to determine the individual amounts of these three components of winter base flow. The first was determined by using a base-flow separation technique that was found to perform better than other commonly used methods for years when periods of zero flow occurred in the fall or spring. After separation of stormflow peaks, the remaining winter base-flow record is representative of both release from temporary storage in the alluvial aquifer and inflow from regional groundwater.

The winter base-flow volume was calculated by summing base flow from the annual hydrograph between a start date in the fall and an end date in the spring. The start date was determined as either the first day that flow returned to the Tombstone gage following its cessation earlier in the fall, the first date of continuous increase in streamflow in the fall, or more rarely, a day based on the relation found in other years between the annual 25th-percentile mean daily flow and the winter base-flow volume. Tombstone base flow thus calculated varies from a low of 1,220 acre-ft in 1998 to a high of 20,600 acre-ft in 1985. The period of record at the Tombstone gage is from 1967 to 1986 and 1997 to present. Considering every year, the median annual base flow is 4,890 $\pm 1,020$ acre-ft. If only the early period of record is considered, median base flow is 5,830 acre-ft; if only the late period is considered, median base flow is 2,880 acre-ft. In dry years, the proportion of streamflow that is considered base flow is 100 percent (that is, no streamflow was removed in the base-flow separation process). In wetter years, 50 percent or less of all streamflow is considered base flow.

A locally weighted least squares (LOWESS) model that related winter base-flow volume to streamflow during the month of October and rainfall during December and January was found to explain 90 percent of the annual variation in base-flow volume. After removing the effect of October streamflow and December-January rainfall, we determined that there is a less than 1 percent chance that there is no difference in base-flow volume between the early period and late period $(p=0.003)$. In other words, there is probably a decrease in base flow that is caused by something other than climate. Only the two downstream gages, Charleston and Tombstone, showed a distinct difference between an early period (1968 to 1982) and a late period (1997 to 2009), suggesting that the decreased flow is caused by conditions below the upstream Palominas gage. The decrease in winter base flow at the Tombstone gaging station could be due to (1) a decrease in inflow from regional groundwater, (2) an increase in ET, either because of increased vegetation or a longer growing season caused by later freeze dates in the fall, and (or) (3) error in the regression model structure or data. 
The relative contribution to base flow of regional groundwater and summer monsoon runoff stored as alluvial groundwater were determined using environmental isotopes. Although the isotopic signature of monsoon water varies widely, the 10-yr record of isotope samples along the San Pedro River allows for a reasonably accurate assessment. Comparing the end-member isotopic compositions to the composition of mixed winter base-flow water at the Tombstone gage, $74 \pm 10$ percent of base flow is derived from regional groundwater. Applying this percentage to the median annual winter base-flow volume for the later period of record at the Tombstone gage gives a value for regional groundwater contribution to winter base flow of 2,130 acre-ft.

Considering the appropriate amount of base flow to include in a water-budget analysis, we realize that base flow varies widely from year to year as a function of annual rainfall (in particular, late monsoon rain and early winter precipitation). To determine average base flow, we must define "average" climate. Similarly, future predictions of base flow must make an assumption of future climate. Because the early period of record at the Tombstone gage represents wetter climate than the long-term average, it alone is not representative of base flow. Climate during the late period is more representative of the long-term average, but this period also exhibits a decline in base flow from the early period independent of climate, likely due to an increase in ET. The Tombstone gage is more sensitive to changes in ET than the upstream Charleston gage, not only because there is simply more upstream vegetation, but also because losing conditions in the alluvial aquifer between the gages allow base flow to be captured if a storage deficit (such as caused by ET) exists.
Ultimately, the streamflow record at the Charleston gage is more representative of common notions of base flow and less sensitive to changes in ET.

Frequently, base flow is considered the minimum amount of streamflow that might be expected, in the absence of precipitation. At the Tombstone gage, this is not the casethe variation in annual rainfall has a dominant effect on the amount of base flow. Because of losing conditions upstream of the Tombstone gage, the amount of base-flow infiltration varies depending on the saturation of the alluvial aquifer after the previous monsoon. Following a wet monsoon, little infiltration of base flow occurs, and base flow measured at the Tombstone gage is high. In dry years, infiltration is high and a large amount of base flow is stored in the alluvial aquifer. The driest summer recorded at the Tombstone gage, in 2009, resulted in 2010 winter base flow that started significantly later (about 1 month) and at a lower rate than previous years. Without winter rain, measured winter flow at the Tombstone gage would have been much less than in any previous year.

Hydraulic gradient and isotope data presented in this report provide essential information for understanding base flow in the San Pedro River. The extensive monitoring network established in the Upper San Pedro Basin is a collaborative effort of the U.S. Geological Survey, the Bureau of Land Management, and the Agricultural Research Service in cooperation with the organizations and agencies that form the Upper San Pedro Patnership. Continued data collection is important for future investigations. Further understanding of San Pedro base flow would come about through development of an integrated surface water/groundwater model, an effort for which historic and future data will play an important role. 


\section{References Cited}

Arizona Department of Commerce, 2010, 2009 Commerce population estimates: http://www.azcommerce.com/doclib/ econinfo/FILES/00alphanew.xls/ (last accessed September 13, 2010).

Arizona Department of Water Resources, 2005a, Groundwater resources of the Upper San Pedro Basin, Arizona: Phoenix, Arizona Department of Water Resources, 85 p.

Arizona Department of Water Resources, 2005b, Upper San Pedro Basin active management area review report: Phoenix, Arizona Department of Water Resources, 219 p.

Baillie, M.N., Hogan, J.F., Ekwurzel, B., Wahi, A.K., Eastoe, C., 2007, Quantifying water sources to a semiarid riparian ecosystem, San Pedro River, Arizona: Journal of Geophysical Research, v. 112, doi:10.1029/2006JG000263.

Bedient, P.B., and Huber, W.C., 1992, Hydrology and floodplain analysis (2nd ed.): Reading, MA, Addison-Wesley, p. 89-94.

Boughton, W.C., 1993, A hydrograph-based model for estimating the water yield of ungauged catchments: Newcastle, NSW, Australia, Institution of Engineers, Proceedings of the Hydrology and Water Resource Symposium, Publication 93/14, p. 317-324.

Brown, S.G., Davidson, E.S., Kister, L.R., and Thomsen, B.W., 1966, Water resources of Fort Huachuca Military Reservation, southeastern Arizona: U.S. Geological Survey Water-Supply Paper 1819-D, p. D1-D57.

Bryan, K., Smith, G.E.P., and Waring, G.A., 1934, Groundwater supplies and irrigation in San Pedro Valley, Arizona: U.S. Geological Survey Open-File Report 67-31, 107 p.

Bureau of Land Management, 1989, San Pedro River riparian management plan and environmental impact statement for the San Pedro River EIS Area, Cochise County, Arizona: U.S. Department of the Interior, 95 p, http://www.blm.gov/ az/st/en/info/nepa/environmental_library/arizona_resource management/san_pedro_river_riparian.html/ (last accessed September 13, 2010).

Chapman, T., 1999, A comparison of algorithms for streamflow recession and base flow separation: Hydrological Processes, v. 13, p. 701-714.

Clark, I., Fritz, P., 1997, Environmental Isotopes in Hydrology: Boca Raton, Florida, CRC Press, 328 p.

Coes, A.L., and Pool, D.R., 2005, Ephemeral-stream channel and basin-floor infiltration and recharge in the Sierra Vista subwatershed of the Upper San Pedro Basin, southeastern Arizona: U.S. Geological Survey Open-File Report 20051023, 63 p.
Corell, S.W., Corkhill, F., Lovvik, D., and Putnam, F., 1996, A groundwater flow model of the Sierra Vista Subwatershed of the Upper San Pedro Basin, southeastern Arizona: Phoenix, Arizona Department of Water Resources Modeling Report No. 10, 107 p.

Department of the Interior, 2008, Water management of the regional aquifer in the Sierra Vista subwatershed, Arizona-2004 report to Congress: Sierra Vista, Ariz., Upper San Pedro Partnership, 36 p., http://www.usppartnership. com/docs/Sec3212007Rep011309.pdf/ (last accessed September 13, 2010).

Eckhardt, K., 2005, How to construct recursive digital filters for base flow separation-Hydrological Processes, v. 19, p. 507-515.

Ferguson, C.A., Shipman, T.C., Pearthree, P.A., Moore, E.M., Richard, S.M., and Spencer, J.E., 2006, Geological map of the Fairbank 7.5' quadrangle, Cochise County, Arizona: Tucson, Arizona Geological Survey Digital Geologic Map 50 (DGM-50), version 1.0, 1 sheet, 1:24,000 (1 CD-ROM with 1 Adobe Acrobat file, 1 Microsoft Word document file).

Freethey, G.W., 1982, Hydrologic analysis of the Upper San Pedro Basin from the Mexico-United States International Boundary to Fairbank, Arizona: U.S. Geological Survey Open-File Report 82-752, 60 p.

Freeze, R.A., and Cherry, J.A, Groundwater, 1979: Englewood Ciffs, N.J., Prentice-Hall, p. 217-226.

Gat, J.R., 1996, Oxygen and hydrogen isotopes in the hydrologic cycle, Annual Review of Earth Planet Science, v. 24, p. 225-262.

Gettings, M.E., and Houser, B.B., 2000, Depth to bedrock in the upper San Pedro Valley, Cochise County, southeastern Arizona: U.S. Geological Survey Open-File Report 00-138, http://pubs.usgs.gov/of/2000/of00-138/ (last accessed September 13, 2010).

Goode, Tomas, and Maddock, Thomas, III, 2000, Simulation of groundwater conditions in the Upper San Pedro Basin for the evaluation of alternative futures: Tucson, Department of Hydrology and Water Resources and University of Arizona Research Laboratory for Riparian Studies, HWR no. $00-30,113$ p.

Goodrich, D.C., Scott, R., Qic, J., Goff, B., Unkrich, C.L., Moran, M.S., Williams, D., Schaeffer, S., Snyder, K., MacNish, R., Maddock, T., Pool, D., Chehbouni, A., Cooper, D.I., Eichinger, W.E., Shuttleworth, W.J., Kerri, Y., Marsett, R., and Nia, W., 2000, Seasonal estimates of riparian evapotranspiration using remote and in situ measurements: Agricultural and Forest Meteorology, v. 105, p. 281-309.

Goodrich, D.C., Williams, D.G., Unkrich, C.L., Hogan, J.F., Scott, R.L., Hultine, K.R., Pool, D., Coes, A.L., and Miller S., 2004, 
Comparison of methods to estimate ephemeral channel recharge, Walnut Gulch, San Pedro River Basin, Arizona, in Hogan, J.F., Phillips, F.M., and Scanlon, B.R., eds., Groundwater recharge in a desert environment-The Southwestern United States: American Geophysical Union, Water Science and Application Series, v. 9, p. 77-99.

Gungle, B., 2005, Timing and duration of flow in ephemeral streams of the Sierra Vista subwatershed of the Upper San Pedro Basin, Cochise County, southeastern Arizona: U.S. Geological Survey Scientific Investigations Report 2005-5190, $56 \mathrm{p}$.

Hall, F.R., 1968, Base-flow recessions-A review: Water Resources Research, v. 4, p. 973-983.

Helsel, D.R., and Hirsch, R.M., 2002, Statistical methods in water resources: U.S. Geological Survey Techniques of Water-Resources Investigations, book 4, chap. A3, 510 .

Hereford, Richard, 1993, Entrenchment and widening of the upper San Pedro River, Arizona: Geological Society of America Special Paper 282, 46 p.

Insightful, 2001, S-Plus 6 for windows guide to statistics, v. 1: Seattle, Washington, Insightful Corporation, $730 \mathrm{p}$.

Kondolf, G.M., Maloney, L.M., and Williams J.G., 1987, Effects of bank storage and well pumping on base-flow, Carmel River, Monterey County, California: Journal of Hydrology, v. 91, p. 351-369, doi:10.1016/00221694(87)90211-3.

Leake, S.A., Pool, D.R., and Leenhouts, J.M., 2008, Simulated effects of ground-water withdrawals and artificial recharge on discharge to streams, springs, and riparian vegetation in the Sierra Vista subwatershed of the Upper San Pedro Basin, southeastern Arizona: U.S. Geological Survey Scientific Investigations Report 2008-5207, 22 p.

Leenhouts, J.M., Stromberg, J.C., and Scott, R.L., 2005, Hydrologic requirements of and consumptive groundwater use by riparian vegetation along the San Pedro River, Arizona: U.S. Geological Survey Scientific Investigations Report, 2005-5163, $211 \mathrm{p}$.

Meyboom, P., 1961, Estimating groundwater recharge from stream hydrographs: Journal of Geophysical Research, v. 66, p. 1203-1204.

Phillips, D.L., and Gregg, J.W., 2001, Uncertainty in source partitioning using stable isotopes: Oecologia, v. 127, p. 171-179.

Pool, D.R., and Coes, A.L., 1999, Hydrogeologic investigations of the Sierra Vista subbasin of the upper San Pedro River basin, Cochise County, Arizona: U.S. Geological Survey Water-Resources Investigations Report 99-4197, 47 p., 3 plates.
Pool, D.R., and Dickinson, J.E., 2007, Ground-water flow model of the Sierra Vista subwatershed and Sonoran portions of the Upper San Pedro Basin, southeastern Arizona, United States and Northern Sonora, Mexico: U.S. Geological Survey Scientific Investigations Report 2006-5228, 60 p.

Révész, K., and Coplen, T.B., 2008a, Determination of the delta $(2 \mathrm{H} / 1 \mathrm{H})$ of water in Révész, K., and Coplen, T.B., eds., Methods of the Reston Stable Isotope Laboratory: U.S. Geological Survey Techniques and Methods, RSIL lab code 1574, chap. 10-C1, 27 p.

Révész, K., and Coplen, T.B., 2008b, Determination of the delta $\left({ }^{18} \mathrm{O} /{ }^{16} \mathrm{O}\right)$ of water in Révész, K., and Coplen, T.B., eds., Methods of the Reston Stable Isotope Laboratory: U.S. Geological Survey Techniques and Methods, RSIL lab code 489, chap. 10-C2, 28 p.

Rutledge, A.T., 1998, Computer programs for describing the recession of ground-water discharge and for estimating mean ground-water recharge and discharge from streamflow records-Update: U.S. Geological Survey Water Resources Investigations Report 98-4148, $52 \mathrm{p}$.

Schmerge, D., Corkhill, F., Flora, S., 2009, Water-level conditions in the Upper San Pedro Basin, Arizona, 2006: Phoenix, Arizona Department of Water Resources, ADWR Water Level Change Map Series, Report No. 3, 3 plates.

Scott, R.L., Goodrich, D., Levick, L., McGuire, R., Cable, W., Williams, D., Gazal, R., Yepez, E., Ellsworth, P., Huxman, T., 2006. Determining the riparian groundwater use within the San Pedro Riparian National Conservation Area and the Sierra Vista Subwatershed, Arizona, in Leenhouts, J.M., Stromberg, J.C., Scott, R.L., eds., Hydrologic requirements of and consumptive ground-water use by riparian vegetation along the San Pedro River, Arizona: U.S. Geological Survey Scientific Investigations Report 2005-5163, chap. D, p. $107-152$.

Shipman, T.C., and Ferguson, C.A., 2006, Geological map of the Land 7.5' quadrangle: Arizona Geological Survey digital geologic map 49 (DGM-49), version 1.0, 1 sheet, scale 1:24,000 (1 CD-ROM with 1 Adobe Acrobat file).

Shirmohammadi, A., Knisel, W.G., and Sheridan, J.M., 1984, An approximate method for partitioning daily streamflow data: Journal of Hydrology, v. 74, p. 335-354.

Sloto, R.A., and Crouse, M.Y., 1996, HYSEP-A computer program for streamflow hydrograph separation and analysis: U.S. Geological Survey Water Resources Investigations Report 96-4040, 46 p.

Smakhtin, 2001, Low flow hydrology —A review: Journal of Hydrology, v. 240, p. 147-186.

Squillace, P.J., 1996, Observed and simulated movement of bank-storage water: Ground Water, v. 34, p. 121-134. 
Stromberg, J.C., Tluczek, M., Hazelton, A., Ajami, H., 2010, A century of riparian forest expansion following extreme disturbance-Spatiotemporal change in Populus/Salix/ Tamarix forests along the upper San Pedro River, Arizona, USA: Forest Ecology and Management, doi:10.1016/j. foreco.2010.01.005.

Thomas, B.E., and Pool, D.R., 2006, Trends in streamflow of the San Pedro River, southeastern Arizona, and regional trends in precipitation and streamflow in southeastern Arizona and southwestern New Mexico: U.S. Geological Survey Professional Paper 1712, 92 p.

Todd, D.K., 1980, Groundwater hydrology (2d ed.): New York, John Wiley \& Sons, p. 222-230.

U.S. Army Corps of Engineers, 1999, Engineering and design, groundwater hydrology, engineer manual: Washington, D.C., U.S. Army Corps of Engineers, manual 1110-1421, chap. $6,18 \mathrm{p}$.
Vionnet, L.B., and Maddock, Thomas, III, 1992, Modeling of ground-water flow and surface/ground-water interaction for the San Pedro River basin, Mexican border to Fairbank, Arizona [pt. 1]: Tucson, University of Arizona, Department of Hydrology and Water Resources report 92-010, 202 p.

Wahi, A.K., 2005, Quantifying mountain system recharge in the Upper San Pedro Basin, Arizona, using geochemical tracers: Tucson, University of Arizona, M.S. thesis, 122 p.

Whitaker, M.L.P., 2000, Estimating bank storage and evapotranspiration using soil physical and hydrological techniques in a gaining reach of the San Pedro River, Arizona: Tucson, University of Arizona, Ph.D. dissertation.

Whiting, P. J., Pomeranets, M., 1997, A numerical study of bank storage and its contribution to streamflow: Journal of Hydrology, v. 202, p. 121-136, doi:10.1016/S00221694(97)00064-4. 
Appendix 1. Annual hydrographs showing measured flow (black) and output from base-flow separation (measured flow with storm runoff removed, red). Vertical dotted lines are the start date of winter base flow used for base flow volume calculation.
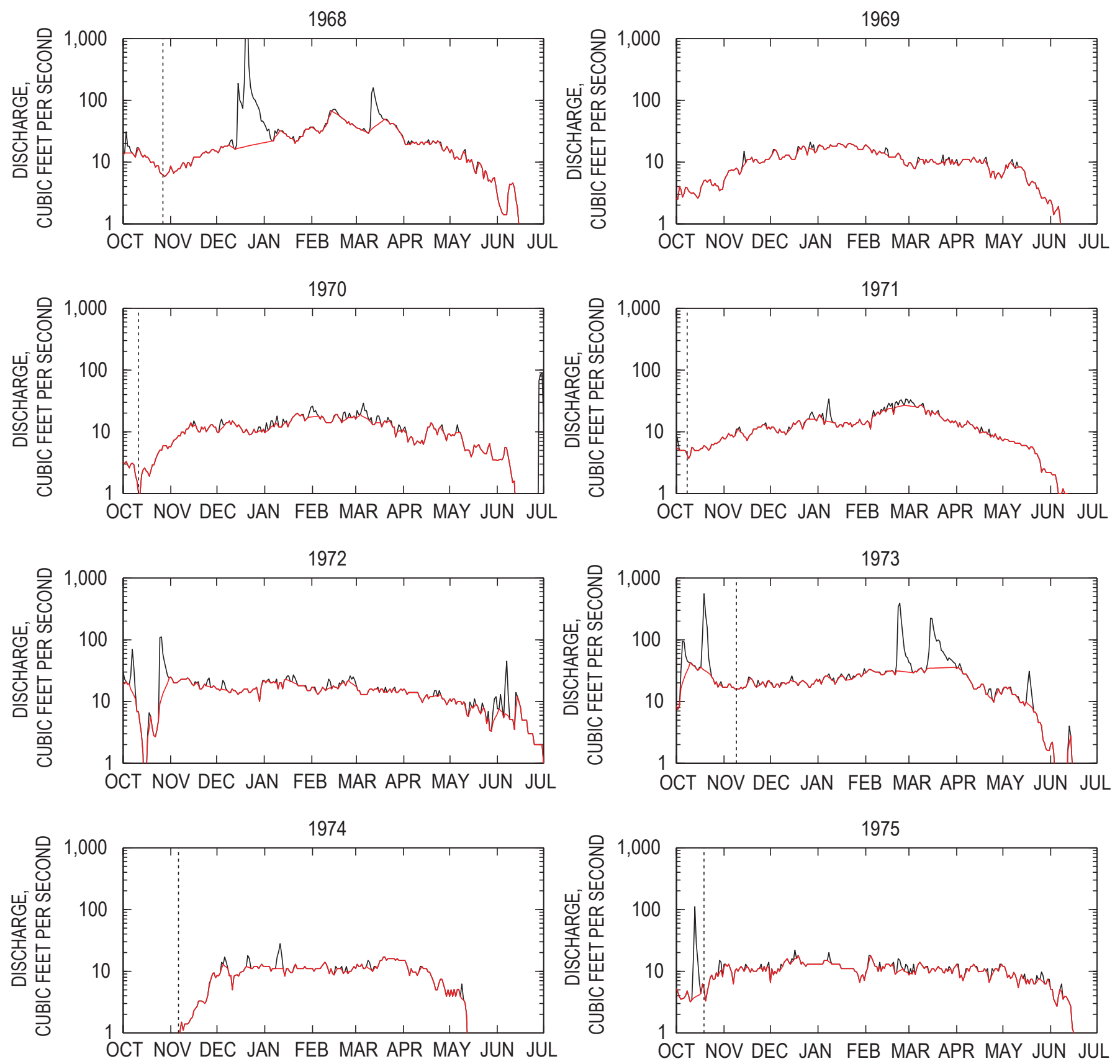

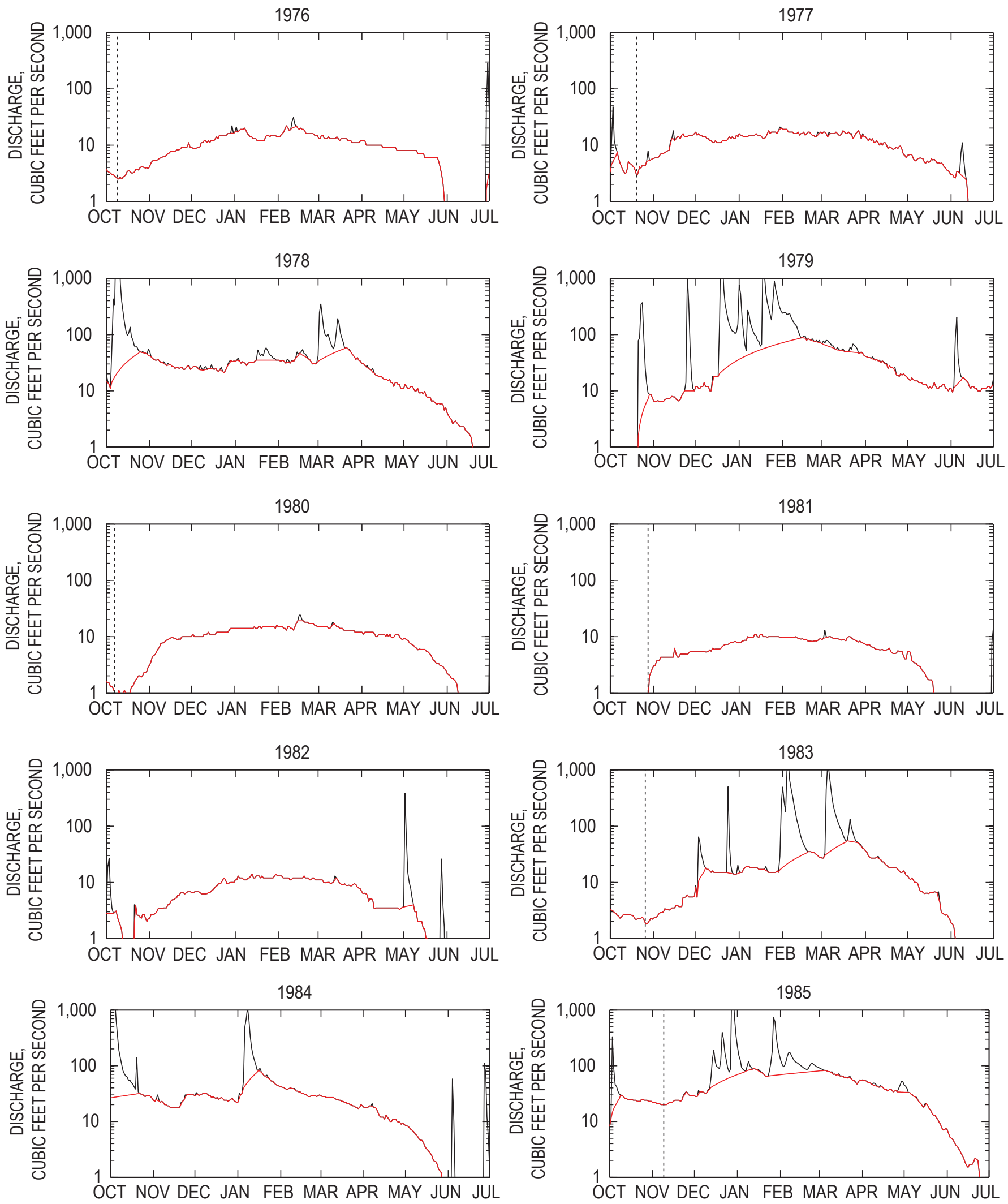

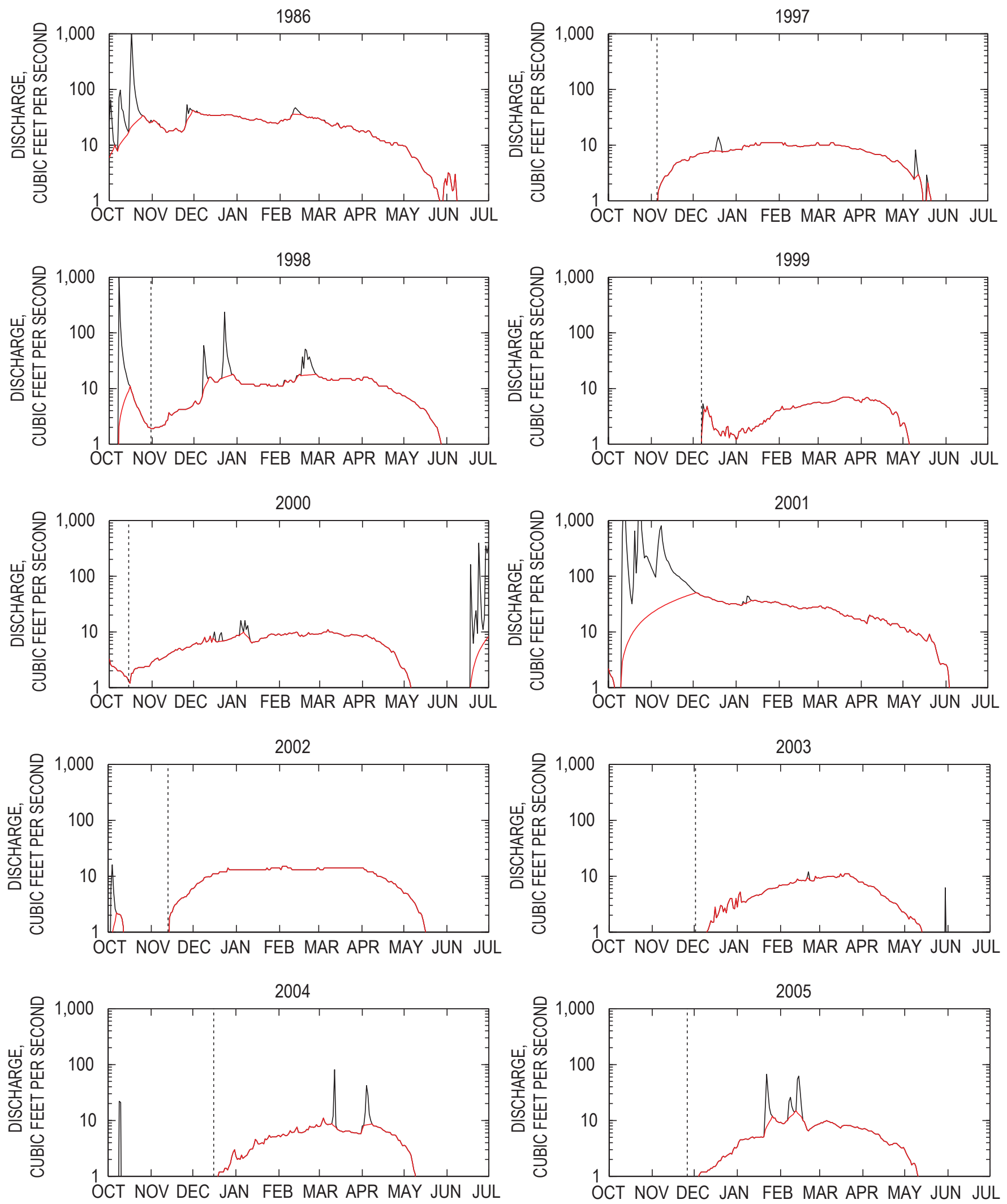
Appendix 1. $\quad 43$
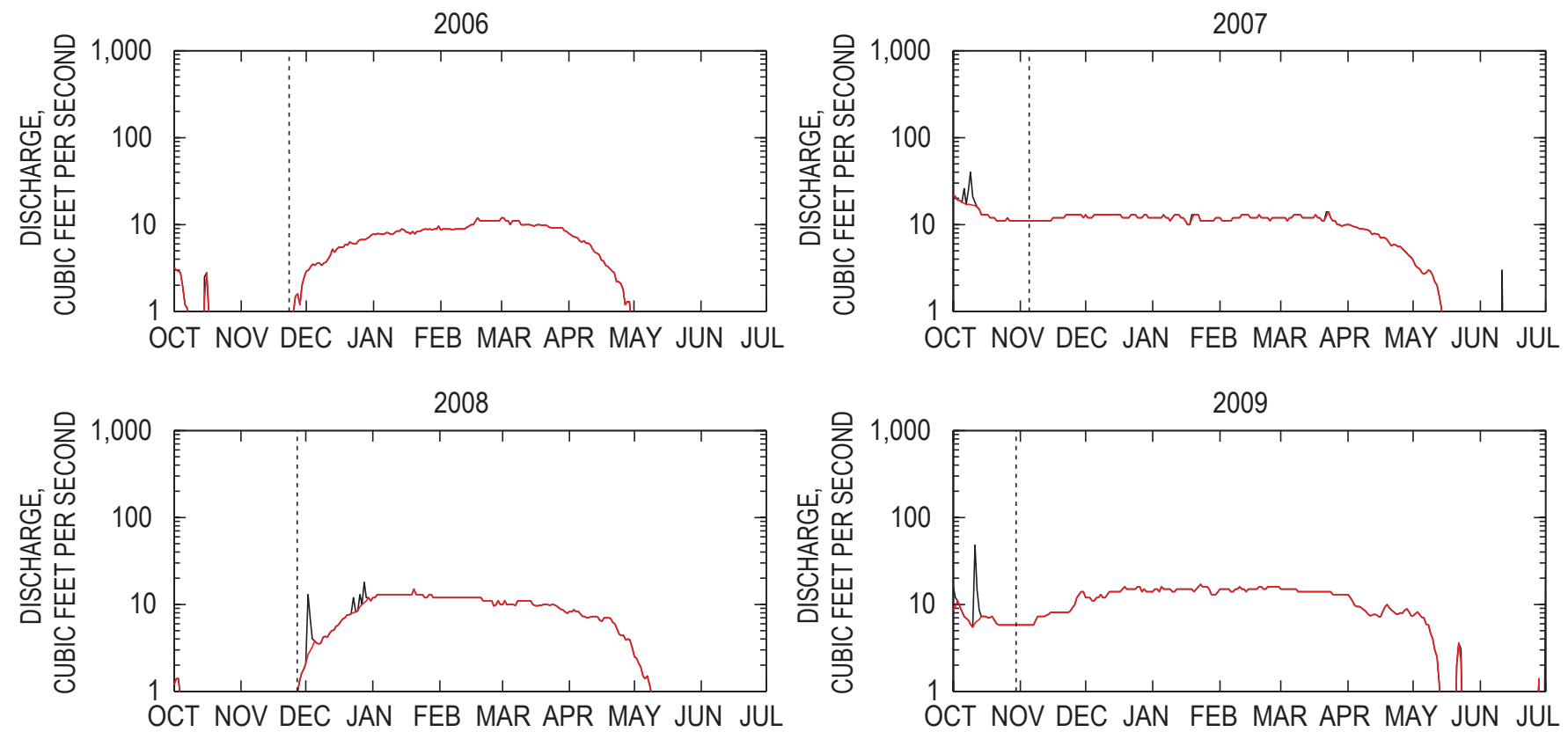
Produced in the Western Region, Menlo Park, California Manuscript approved for publication September 19, 2010

Text edited by Jan Zigler

Layout and design by Judy Weathers 
